\title{
Recent Advances in the Catalytic Synthesis of Imidazolidin-2-ones and Benzimidazolidin-2-ones
}

\author{
Alessandra Casnati ${ }^{1}$, Elena Motti ${ }^{1}$, Raffaella Mancuso ${ }^{2}$ (D) Bartolo Gabriele ${ }^{2}(\mathbb{D}$ and \\ Nicola Della Ca' 1,*(D) \\ 1 Department of Chemistry, Life Sciences and Environmental Sustainability (SCVSA), University of Parma, \\ Parco Area delle Scienze 17/A, 43124 Parma (Pr), Italy; alessandra.casnati@studenti.unipr.it (A.C.); \\ elena.motti@unipr.it (E.M.) \\ 2 Laboratory of Industrial and Synthetic Organic Chemistry (LISOC), Department of Chemistry and Chemical \\ Technologies, University of Calabria, Via Pietro Bucci 12/C, 87036 Arcavacata di Rende (CS), Italy; \\ raffaella.mancuso@unical.it (R.M.); bartolo.gabriele@unical.it (B.G.) \\ * Correspondence: nicola.dellaca@unipr.it; Tel.: +39-0521-90-5676
}

Received: 30 November 2018; Accepted: 20 December 2018; Published: 1 January 2019

\begin{abstract}
Imidazolidinone and its analogues are omnipresent structural motifs of pharmaceuticals, natural products, chiral auxiliaries, and intermediates in organic syntheses. Over the years, continuous efforts have been addressed to the development of sustainable and more efficient protocols for the synthesis of these heterocycles. This review gives a summary of the catalytic strategies to access imidazolidin-2-ones and benzimidazolidin-2-ones that have appeared in the literature from 2010 to 2018. Particularly important contributions beyond the timespan will be mentioned. The review is organized in four main chapters that identify the most common approaches to imidazolidin-2-one derivatives: (1) the direct incorporation of the carbonyl group into 1,2-diamines, (2) the diamination of olefins, (3) the intramolecular hydroamination of linear urea derivatives and (4) aziridine ring expansion. Methods not included in this classification will be addressed in the miscellaneous section.
\end{abstract}

Keywords: metal catalysis; organocatalysis; carbonylation reactions; diamination; hydroamination; 2-imidazolidinones; 2-benzimidazolidinones; 5-membered cyclic ureas

\section{Introduction}

Imidazolidin-2-ones and their analogues are widely found in pharmaceuticals, natural alkaloids, and other biologically active compounds (Figure 1) [1-4]. Substituted imidazolidin-2-ones are also important synthetic intermediates that can be transformed into a broad variety of complex structures [5-10], and represent a useful class of chiral auxiliaries for asymmetric transformations [11-13]. Over the past decades, various synthetic routes to access five-membered cyclic ureas have been explored, and substantial advances have been accomplished in the aim of producing more sustainable and environmental-friendly protocols for the preparation of this essential class of molecules. The most common synthetic approach to imidazolidin-2-ones and benzimidazolidin-2-ones is based on the direct incorporation of a carbonyl group into a vicinal diamine (Section 2). A wide variety of carbonylating agents have been explored, and in this context, the catalytic incorporation of carbon monoxide or carbon dioxide can be considered a more sustainable and atom economical alternative compared to the use of toxic carbonylating agents such as phosgene. The transition metal-catalyzed diamination of olefins, thanks to the valuable contributions of Lloyd-Jones, Muñiz and Shi, has been well explored, and is actually an extremely useful tool for the synthesis of richly decorated 2-imidazolidinones in an enantioselective fashion as well (Section 3). Both metals and bases have been exploited to promote the intramolecular hydroamination of urea-tethered alkenes and alkynes (Section 4). 
<smiles>Nc1ccc(C(=O)N2CCc3ccc(S(=O)(=O)N4C[C@@H](c5ccccc5)NC4=O)cc32)cc1</smiles><smiles>O=C1NC2n3c(cc(Br)c3Br)C(=O)N3CCCC23N1</smiles>

Dibromophakellstatin antineoplastic agent<smiles>O=c1[nH]c2ccccc2n1C1CCN(CCCC(Pc2ccccc2)P(Pc2ccccc2)c2ccccc2)CC1</smiles><smiles>COc1noc(C)c1-c1cc(-c2ccccc2)c2[nH]c(=O)[nH]c2c1</smiles>

ArO<smiles>CN1C[C@@](COCc2cc(C(F)(F)F)cc(C(F)(F)F)c2)(c2ccccc2)NC1=O</smiles>
enterovirus E71<smiles>Cc1ccc(NN2CCN(c3ccncc3)C2=O)cc1</smiles>
antagonist<smiles>CCCCOc1nc(-c2cccc3[nH]c(=O)[nH]c23)nc(N2CCOCC2)n1</smiles>

phosphoinositide 3-kinase activator

Figure 1. Selected 2-imidazolidinone and 2-benzimidazolidinone-containing bioactive compounds.

Finally, aziridines may be versatile substrates to obtain five-membered cyclic ureas through the reaction with isocyanates (Section 5). Palladium or nickel-based catalysts can be employed for this purpose. Methods not included in this classification will be also treated in the miscellaneous section (Section 6). Therefore, progress in the synthesis of 2-(benz)imidazolidinone core is updated in this paper, which references the literature from 2010 to 2018. However, particularly important contributions beyond the timespan will be also considered. The preparation of hydantoins [14] and 2 -imidazolones [15] will not be treated in view of very recent reviews on these topics. For the convenience of the reader, essential breaking and forming bonds are highlighted in blue and red, respectively.

\section{Synthesis of 2-(benz)imidazolidinones by Direct Incorporation of the Carbonyl Group into 1,2-Diamines}

The direct incorporation of the carbonyl group into 1,2-diamines is an excellent approach for synthesizing imidazolidin-2-one and benzimidazolidin-2-one derivatives (Scheme 1). Over the years, several different species that are able to "transfer" the carbonyl group (carbonylating agents) have been employed for this purpose, in some cases under the action of a suitable catalytic system. 
<smiles>[Y][Z7]Nc1ccccc1N[R]</smiles>

Scheme 1. Synthesis of (benz)imidazolidin-2-ones by direct carbonyl insertion into 1,2-diamines. $\mathrm{A}(\mathrm{CO}) \mathrm{B}$ represents a generic agent that is able to transfer the carbonyl group. In some cases, the process is carried out in the presence of a suitable catalyst.

The carbonylating agents employed under stoichiometric conditions are characterized by the presence of two efficient leaving groups bonded to the carbonyl ( $\mathrm{A}, \mathrm{B}=\mathrm{LG}$; $\mathrm{LG}=$ leaving group). In this way, a nucleophilic attack by an amino group of the substrate on the carbonyl of the (LG) ${ }_{2} \mathrm{C}=\mathrm{O}$ species leads to an intermediate from which the final (benz)imidazolidinone product is formed by intramolecular acyl nucleophilic substitution, as shown in Scheme 2. Generally speaking, aliphatic 1,2-diamines are more nucleophilic, and therefore more reactive with respect to benzene-1,2-diamines.

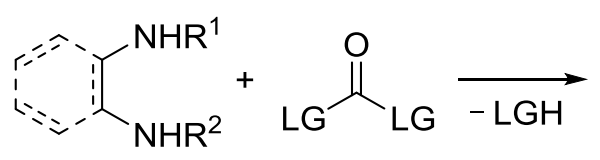<smiles>[R]Nc1ccccc1N([R])C(=O)[GeH3]</smiles><smiles>[R2]n1c(=O)n([R2])c2ccccc21</smiles>

Scheme 2. Mechanism of the formation of (benz)imidazolidin-2-ones from 1,2-diamines and a carbonylating agent $(\mathrm{LG})_{2} \mathrm{C}=\mathrm{O}(\mathrm{LG}=$ leaving group) by sequential intermolecular/intramolecular acyl nucleophilic substitution reactions.

The simplest carbonylating agent of this kind is phosgene $(\mathrm{A}=\mathrm{B}=\mathrm{Cl})$, which is used in combination with a base (such as a tertiary amine) that is necessary to buffer the two equivalents of $\mathrm{HCl}$ that are formally released from the process. Although its use is quite limited due to its toxicity, examples of use of triphosgene are still reported, even in the most recent literature [16-20], as exemplified by the synthesis of the $\beta$-lactam derivative shown in Scheme 3, which is used as a synthetic precursor for the preparation of molecules with antibacterial activity [16].
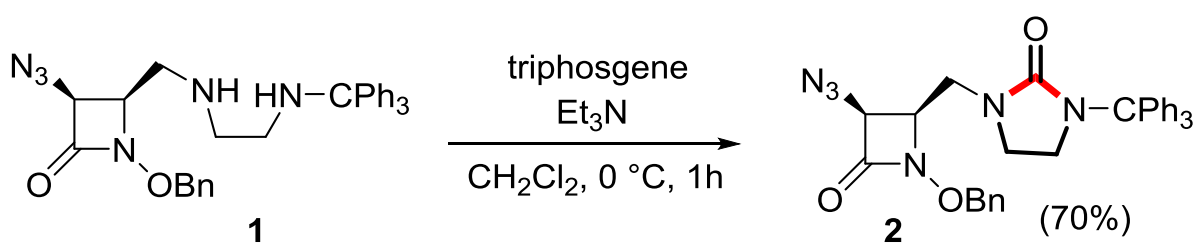

Scheme 3. Synthesis of 3-tritylimidazolidin-2-one 2 from vicinal diamine $\mathbf{1}$ and triphosgene in the presence of trimethylamine as the base [16].

Several useful alternatives to phosgene have been used to perform the carbonyl transfer process shown in Scheme 1. Chloroformates $\left(\mathrm{A}=\mathrm{Cl}, \mathrm{B}=\mathrm{OR}^{3}, \mathrm{R}^{3}=\right.$ alkyl or aryl) are widely employed [21-30]; a recent example, in which the method is applied to a peptide derivative, is shown in Scheme 4 [21]. The use of strictly related $\mathrm{Boc}$ anhydride $\left[\mathrm{A}=\mathrm{O}^{\mathrm{t}} \mathrm{Bu}, \mathrm{B}=\mathrm{O}(\mathrm{CO}) \mathrm{O}^{\mathrm{t}} \mathrm{Bu}\right.$ ] [31-33], 2-phenoxycarbonyl-4,5-dichloropyridazin-3(2H)-one [A = 2-(4,5-dichloro-6-oxopyridazin-1(6H)-yl), $\mathrm{B}=\mathrm{OPh}$ ], [34], dimethylcarbamoyl chloride $\left(\mathrm{A}=\mathrm{Cl}, \mathrm{B}=\mathrm{NMe}_{2}\right)$ [35], ethyl cyanoformate $(\mathrm{A}=\mathrm{CN}$, $\mathrm{B}=\mathrm{OEt})[36]$, and $\beta$-chetoesters $(\mathrm{A}=\mathrm{OEt}, \mathrm{B}=$ enolate) [37-40] has also been reported. 


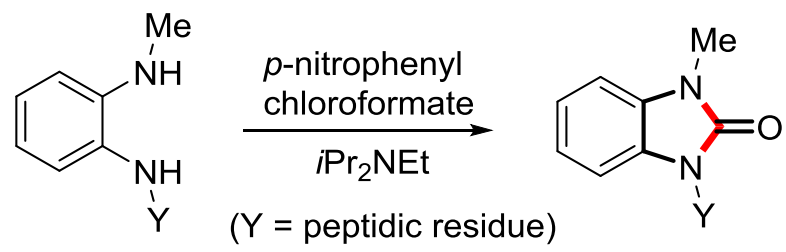

Scheme 4. Formation of a benzimidazolidin-2-one moiety bonded to a peptide residue using p-nitrophenyl chloroformate as the carbonyl transfer agent [21].

Urea $\left(\mathrm{A}=\mathrm{B}=\mathrm{NH}_{2}\right)$ [41-49] and carbonyldiimidazole (CDI; $\mathrm{A}=\mathrm{B}=1$-imidazolyl) [50-62] are also excellent carbonyl transfer agents for the synthesis of cyclic ureas from 1,2-diamines. For example, benzimidazolidinones were efficiently synthesized from 1,2-benzenediamines and urea in the presence of sulfated polyborate under solvent-free conditions (Scheme 5) [41].

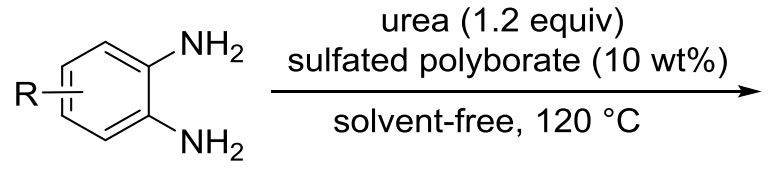

$\left(\mathrm{R}=\mathrm{H}, p-\mathrm{Cl}, p-\mathrm{NO}_{2}, p-\mathrm{Me}, m-\mathrm{Me}\right)$<smiles>O=c1[nH]c2ccccc2[nH]1</smiles>

$(90-94 \%)$

Scheme 5. Synthesis of benzimidazolidin-2-ones from 1,2-benzenediamines using urea as a carbonylating agent under solvent-free conditions [41].

On the other hand, new carbazoles with antihyperglycemic activity, bearing the imidazolidin-2-one moiety, were obtained from the corresponding diamines using CDI in the presence of catalytic amounts of 4-dimethylaminopyridine (DMAP) (Scheme 6) [50].
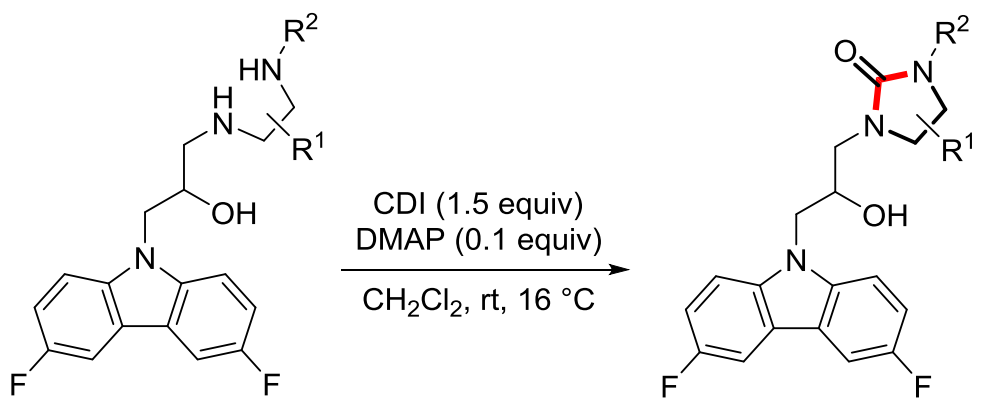

Scheme 6. Synthesis of carbazole derivatives with antihyperglycemic activity, bearing the imidazolidin-2-one moiety, from the corresponding diamines using CDI as carbonyl transfer agent (CDI = carbonyldiimidazole; DMAP = 4-dimethylaminopyridine) [50].

The use of dialkyl carbonates $\left(\mathrm{A}=\mathrm{B}=\mathrm{OR}{ }^{\prime \prime}, \mathrm{R}^{\prime \prime}=\right.$ alkyl) in the presence of suitable catalysts has also been reported. In particular, imidazolidin-2-ones were recently synthesized using $\mathrm{Cu}\left(\mathrm{NO}_{3}\right)_{2}$ as catalyst, which is believed to activate the carbonyl of DMC by O-coordination [63] (Scheme 7). The use of sulfamic acid as the Brønsted acidic catalyst has also been described [64].<smiles>[R]NC([R])CN</smiles>

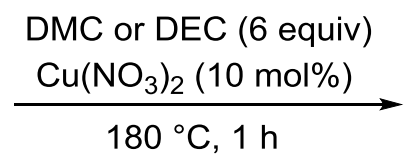<smiles>[R]C1CNC(=O)N1[R]</smiles>

$(56-79 \%)$

Scheme 7. Synthesis of imidazolidin-2-ones by $\mathrm{Cu}(\mathrm{II})$-catalyzed carbonylation of 1,2-diamines with dialkyl carbonates $(\mathrm{DMC}=$ dimethyl carbonate; $\mathrm{DEC}=$ diethyl carbonate) [63]. 
The simplest C-1 units (carbon monoxide and carbon dioxide) are undoubtedly the most attractive carbonylation source for the synthesis of (benz)imidazolidinones from 1,2-diamines both from the point of view of atom economy and availability. Accordingly, many efforts have been made in order to activate them in this process by means of an appropriate catalytic system.

The use of $\mathrm{CO}$ formally requires the elimination of molecular hydrogen, so the carbonylation of 1,2-diamines with carbon monoxide is usually carried out under oxidative conditions [i.e., in the presence of an external oxidant $[\mathrm{OX}]$ that is reduced to $\left[\mathrm{OXH}_{2}\right]$ under the reaction conditions (Scheme 8)].<smiles>[R]Nc1ccccc1N[R7]</smiles><smiles>[R]Nc1ccccc1N[R7][Na]</smiles>

Scheme 8. Formation of (benz)imidazolidin-2-ones by direct carbonylation with carbon monoxide ([OX] = oxidant; $\left[\mathrm{OXH}_{2}\right]=$ reduced oxidant).

The catalytic system consisting of $\mathrm{PdI}_{2}$ in conjunction with $\mathrm{KI}$, which was developed by our research group $[65,66]$ and successfully employed for the oxidative carbonylation of a plethora of acetylenic substrates [67-77], also proved to be efficient for realizing the oxidative carbonylation of aromatic diamines to cyclic ureas, as exemplified in Scheme 9 [78]. In this reaction, the external oxidant is simply molecular oxygen, with the formation of only water as the co-product $([\mathrm{OX}]=$ $\left.(1 / 2) \mathrm{O}_{2},\left[\mathrm{OXH}_{2}\right]=\mathrm{H}_{2} \mathrm{O}\right)$. The carbonylation process starts with nitrogen palladation (from the reaction between an amino group of the substrate and $\mathrm{PdI}_{2}$ ), followed by carbon monoxide insertion to give a carbamoylpalladium iodide intermediate (Scheme 10; anionic iodide ligands are omitted for clarity). Then intramolecular nucleophilic displacement by the second amino group [possibly through the formation of an isocyanate as an intermediate from $\beta$-H elimination from the $\mathrm{HN}(\mathrm{CO}) \mathrm{PdI}$ moiety] takes place to give the cyclic urea and palladium(0) [78]. The latter is then re-oxidized to catalytically active $\mathrm{PdI}_{2}$ according to the mechanism we demonstrated several years ago [66], involving the oxidative addition of $\mathrm{I}_{2}$ to $\mathrm{Pd}(0) ; \mathrm{I}_{2}$ is obtained in situ by oxidation of two equivalents of $\mathrm{HI}$ (also ensuing from the carbonylation process) with $\mathrm{O}_{2}$ (Scheme 10).

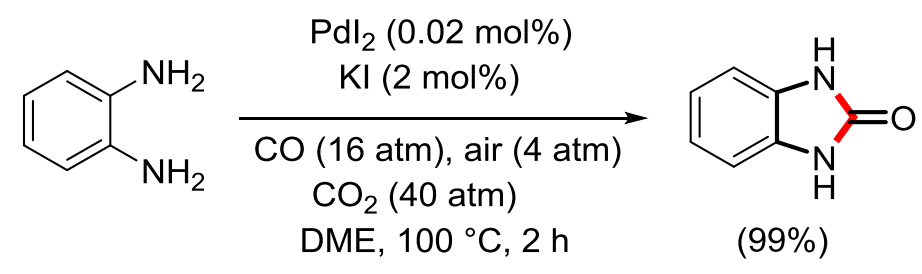

Scheme 9. Synthesis of benzimidazolidin-2-one by $\mathrm{PdI}_{2} / \mathrm{KI}$-catalyzed oxidative carbonylation of 1,2-benzenediamine [78]. 


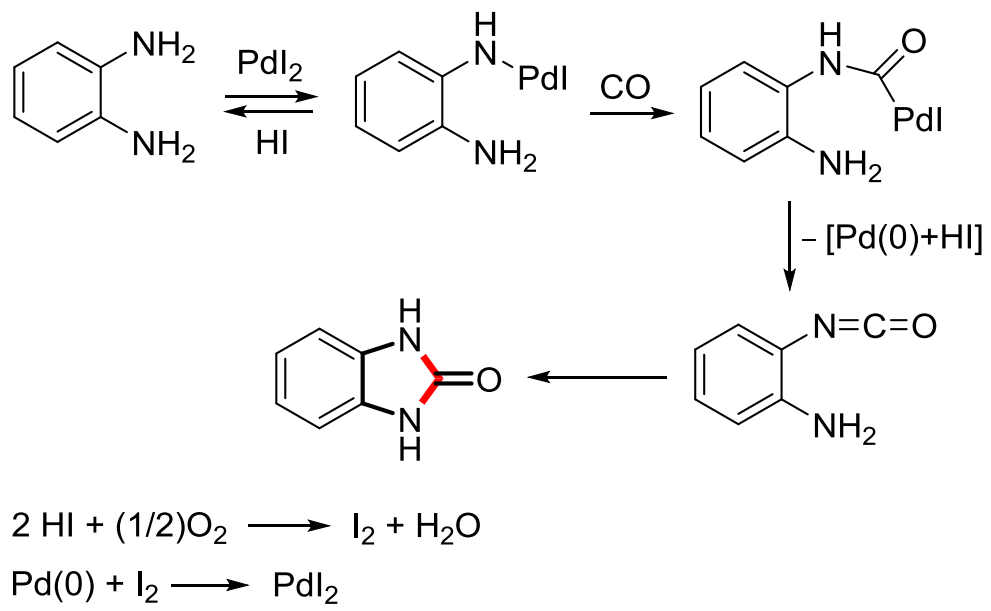

Scheme 10. Mechanism of the $\mathrm{PdI}_{2} / \mathrm{KI}$-catalyzed oxidative carbonylation of 1,2-benzenediamine leading to benzimidazolidin-2-one [78].

More recently, the oxidative carbonylation of benzene-1,2-diamine to benzimidazolidin-2-one was accomplished in a biphasic water-toluene medium using $\mathrm{Pd}(\mathrm{OAc})_{2}$ as palladium(II) source in the presence of BipyDS (disodium 2,2'-bipyridine-4,4'-disulfonate) as the water-soluble ligand [79]. The possibility of incorporating the ${ }^{11} \mathrm{C}$ radioisotope into a benzimidazolidin-2-one moiety using ${ }^{11} \mathrm{CO}$, although in modest yield, has also been demonstrated [80]. The carbonylation of benzene-1,2-diamines in the absence of an external oxidant has been reported using $\mathrm{Pd}(\mathrm{OAc})_{2}$ as the catalyst in the presence of $\mathrm{PPh}_{3}$ and $\mathrm{Et}_{3} \mathrm{~N}$; in this case, the formation of molecular hydrogen accounted for the stoichiometry of the process (Scheme 11) [81].

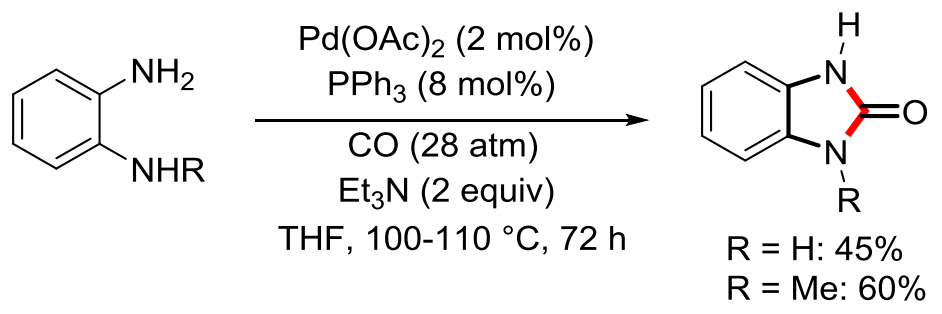

Scheme 11. Carbonylation of 1,2-benzenediamines to benzimidazoimidazol-2-ones in the absence of an external oxidant. The formation of molecular hydrogen accounts for the stoichiometry of the process [81].

Aliphatic 1,2-diamines have also been converted into the corresponding imidazolidin-2-ones under oxidative carbonylation conditions. Thus, $N, N^{\prime}$-dialkylethylenediamines successfully reacted with a $\mathrm{CO} / \mathrm{O}_{2}$ mixture $(2: 1 ; 1 \mathrm{~atm})$ in the presence of a catalytic amount of selenium $(5 \mathrm{~mol} \%)$ at room temperature for 30 minutes. (Scheme 12) [82]. However, it is worth noting that these conditions fall within the flammability range for a $\mathrm{CO} / \mathrm{O}_{2}$ mixture [84]. Mechanistically, the process is believed to occur through the formation of a selenolate intermediate, which then undergoes $\mathrm{CO}$ insertion to give a selenocarbamate species. The latter eventually converts into the final product by intramolecular nucleophilic displacement, with the simultaneous elimination of hydrogen diselenide, which is oxidized back to elemental selenium by the action of oxygen (Scheme 12) [82]. More recently, the palladium-catalyzed oxidative carbonylation of simple ethylenediamine to imidazolidin-2-one ( $72 \%$ yield) (carried out in water at $100{ }^{\circ} \mathrm{C}$ with $1 \mathrm{~mol} \%$ of palladium catalyst, under $40 \mathrm{~atm}$ of a $\mathrm{CO} / \mathrm{O}_{2}$ mixture [84]) was reported [85]. 


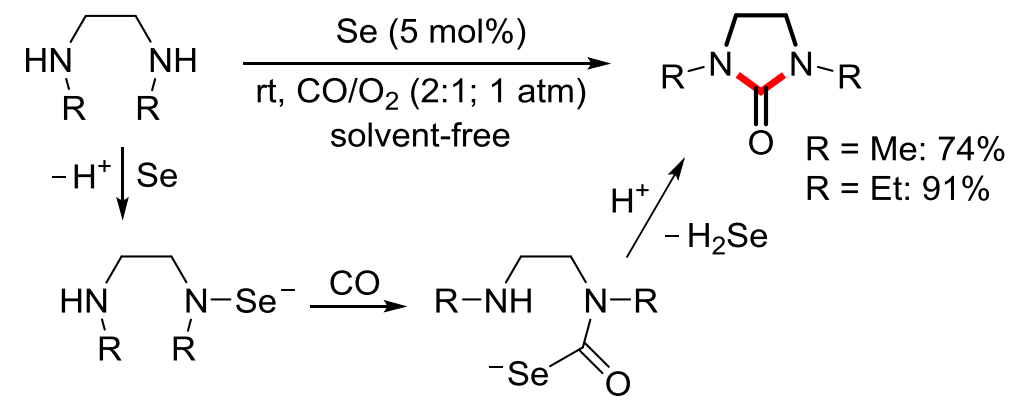

Scheme 12. Synthesis of imidazolidin-2-ones by Se-catalyzed oxidative carbonylation of $N, N^{\prime}$-dialkylethylenediamines [82]. Note that the $2: 1 \mathrm{CO} / \mathrm{O}_{2}$ mixture that was employed falls within the flammability limit [84].

The direct incorporation of the carbonyl group using $\mathrm{CO}_{2}$ as the carbonylation agent is another very attractive approach to (benz)imidazolidin-2-ones. In this case, no external oxidant is needed, and water is produced as a co-product (Scheme 13). Owing to the relative inertness of $\mathrm{CO}_{2}$, the process is usually carried out in the presence of a suitable catalyst. Moreover, in several cases, the use of a dehydrating agent is needed, because the water produced in the course of the process may negatively affect the product yield. However, the possibility of avoiding catalysts as well as organic solvents and other additives or promoters has also been demonstrated with simple aliphatic 1,2-diamines, even though under rather harsh conditions $\left(180^{\circ} \mathrm{C}\right.$ under $100 \mathrm{~atm}$ of $\mathrm{CO}_{2}$ for $\left.24 \mathrm{~h}\right)$ [86].

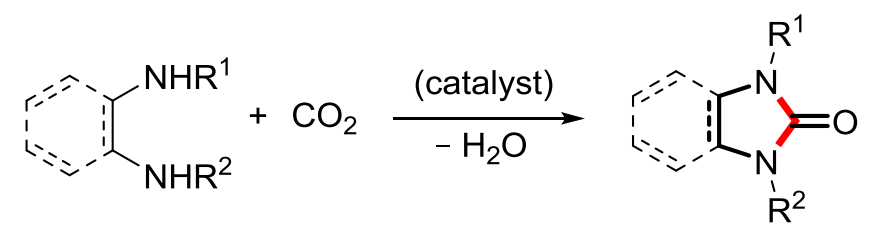

Scheme 13. Carbon dioxide as the carbonyl source in the synthesis of (benz)imidazolidin-2-ones from 1,2-diamines.

The formation of imidazolidin-2-ones from 1,2-diamines and $\mathrm{CO}_{2}$ was efficiently achieved using tetramethylphenylguanidine (PhTMG) as the basic promoter (1-2 equiv) in the presence of diphenylphosphoryl azide (DPPA) as the dehydrative activator (1-1.2 equiv), in either MeCN or $\mathrm{CH}_{2} \mathrm{Cl}_{2}$ as the solvent at $-40{ }^{\circ} \mathrm{C}$ to room temperature (Scheme 14) [87]. The role of DPPA was to activate the carbamate group (obtained from the reaction of the substrate with $\mathrm{CO}_{2}$ and the superbase) toward the intramolecular nucleophilic acyl substitution, through the formation of a mixed anhydride (Scheme 14) [87]. The use of polyethylene glycol-supported potassium hydroxide $\left(\mathrm{KOH} / \mathrm{PEG}_{1000}\right)$, in the absence of dehydrating agents, was also reported [88]. KOH/PEG 1000 was found to act as an efficient and recyclable catalyst (10 mol\% with respect to the substrate) for the conversion of ethylenediamine, propane-1,2-diamine, and cyclohexane-1,2-diamine into the corresponding cyclic ureas. More recently, $\gamma-\mathrm{Al}_{2} \mathrm{O}_{3}$ was reported to catalyze the formation of 1-(2-hydroxyethyl)imidazolidin-2-one from 2-[(2-aminoethyl)amino]ethan-1-ol, at $250{ }^{\circ} \mathrm{C}$ in supercritical $\mathrm{CO}_{2}$ (Scheme 15) [89]. 


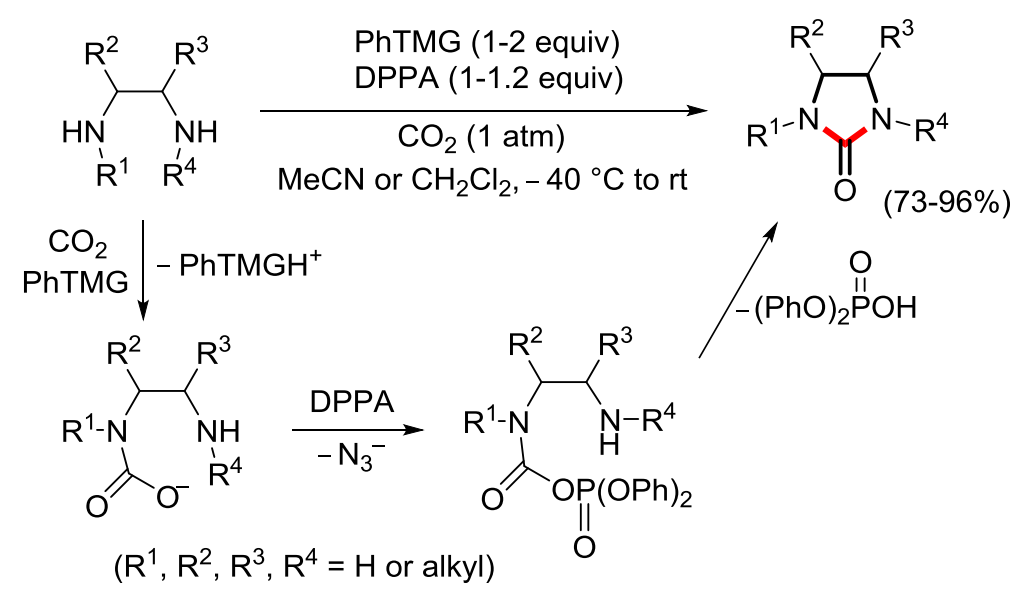

Scheme 14. Synthesis of imidazolidin-2-ones by carbonylation of 1,2-diamines with carbon dioxide carried out in the presence of tetramethylphenylguanidine (PhTMG) as the basic promoter and diphenylphosphoryl azide (DPPA) as the dehydrative activator [87].

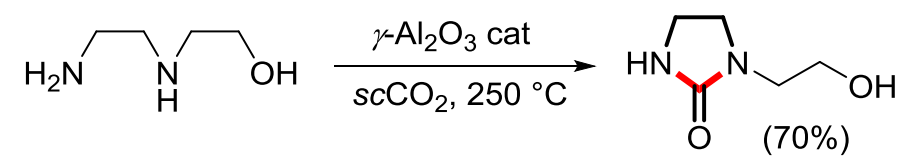

Scheme 15. Formation of 1-(2-hydroxyethyl)imidazolidin-2-one from 2-[(2-aminoethyl)amino]ethan-1-ol in $s c \mathrm{CO}_{2}$ at $250{ }^{\circ} \mathrm{C}$ with $\gamma-\mathrm{Al}_{2} \mathrm{O}_{3}$ as catalyst [89].

Ceria-based materials are also useful heterogeneous catalysts for the conversion of aliphatic 1,2-diamines into imidazolidin-2-ones with $\mathrm{CO}_{2}$. In particular, nanoparticulate $\mathrm{CeO}_{2}$ (obtained by templating with alginate biopolymer) proved to be active for the conversion of ethylenediamine, $N$-(2-aminoethyl)ethane-1,2-diamine, $N, N^{\prime}$-dimethylethane-1,2-diamine, and $\mathrm{N}$-[2-(methylamino)ethyl]acetamide into the corresponding cyclic ureas, even though in low to modest yields (9-37\%) [90]. On the other hand, pure ceria turned out to be a useful recyclable heterogeneous catalyst for the carbonylation with $\mathrm{CO}_{2}$ of a variety of aliphatic 1,2-diamines, in isopropanol as the solvent at $160{ }^{\circ} \mathrm{C}$ and under a relatively low $\mathrm{CO}_{2}$ pressure (five atm) (Scheme 16) [91]. The proposed reaction mechanism for this latter process involves the formation of a carbamate species on ceria, followed by decarboxylation and the intramolecular nucleophilic attack of the amino group to the carbamate moiety (Scheme 16) [91].

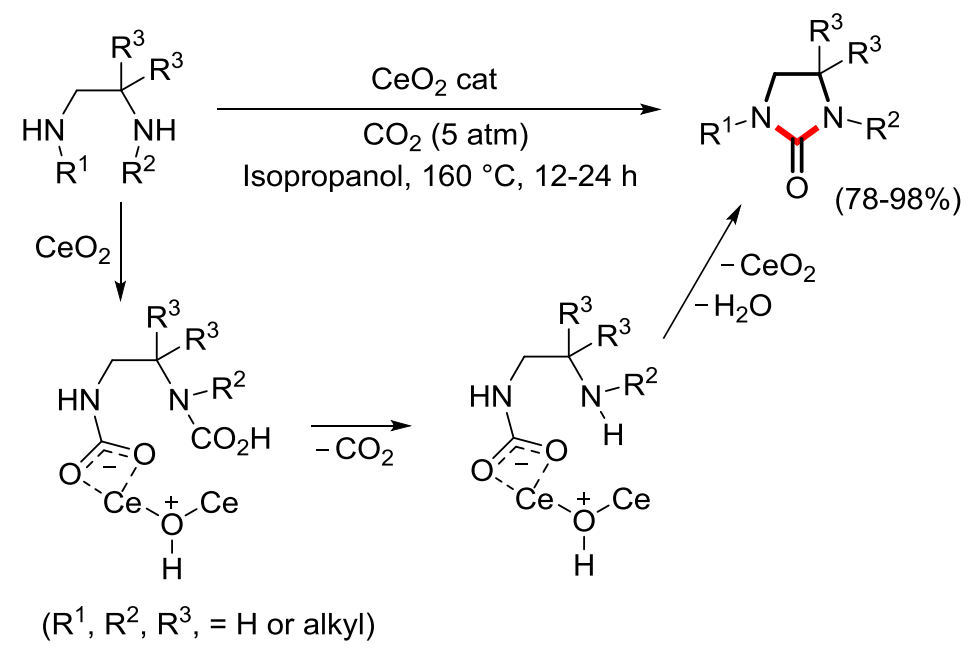

Scheme 16. Synthesis of imidazolidin-2-ones by the $\mathrm{CeO}_{2}$-catalyzed carbonylation of aliphatic 1,2-diamines with $\mathrm{CO}_{2}$ [91]. 
In general, the reaction of 1,2-benzenediamines with $\mathrm{CO}_{2}$ to give benzimidazolidin-2-ones is more challenging, owing to the lower nucleophilicity of the aromatic amino groups. However, to date, different methods are known to carry out this process. Recently, $N, N^{\prime}$-bis(trimethylsilyl)benzene-1,2-diamine was converted into benzimidazolidin-2-one in $73 \%$ yield by reaction with $\mathrm{CO}_{2}(3 \mathrm{~atm})$ at $110{ }^{\circ} \mathrm{C}$ for $12 \mathrm{~h}$ in the presence of pyridine and $\mathrm{In}\left[\mathrm{N}\left(\mathrm{SiMe}_{3}\right)_{2}\right] \mathrm{Cl}_{2} \cdot(\mathrm{THF})_{\mathrm{x}}$ as catalyst (2 mol\%) (Scheme 17) [92]. The process occurs through the formation of an indium amino complex, which reacts with $\mathrm{CO}_{2}$ to give a silyl carbamate. The latter then undergoes intramolecular nucleophilic attack by the second amino moiety to give the cyclic urea with elimination of $\left(\mathrm{Me}_{3} \mathrm{Si}\right)_{2} \mathrm{O}$ (Scheme 17) [92].
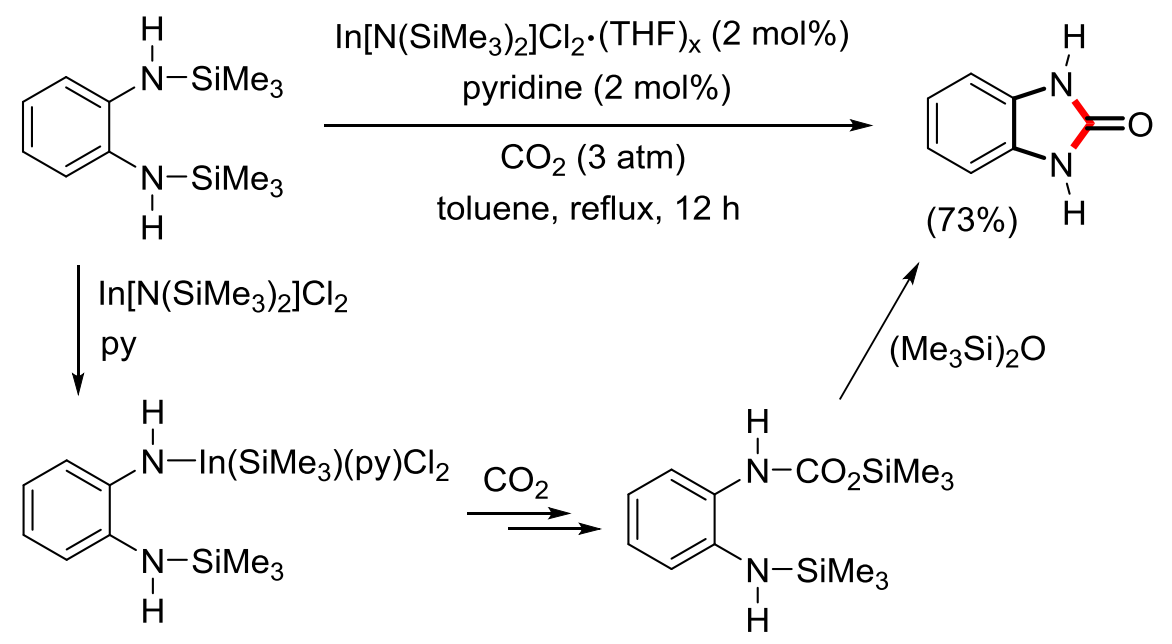

Scheme 17. Indium-catalyzed formation of benzimidazolidin-2-one from $N, N^{\prime}$-bis(trimethylsilyl)benzene-1,2-diamine and $\mathrm{CO}_{2}$ [92].

The carbonylation of 1,2-benzenediamines with $\mathrm{CO}_{2}$ under solventless conditions was realized using the ionic liquid [DBUH][OAc] (DBUH = protonated 1,8-diazabicyclo[5.4.0]undec-7-ene, OAc = acetate anion) as catalyst $(10 \mathrm{~mol} \%)$ at $120{ }^{\circ} \mathrm{C}$ under $90 \mathrm{~atm}$ of $\mathrm{CO}_{2}$ for $24 \mathrm{~h}$ (Scheme 18) [93]. The bifunctional role of the catalyst was to activate both $\mathrm{CO}_{2}$ (cation) and the diamine (anion), as shown in Scheme 18. The reaction did not work with $N, N^{\prime}$-disubstituted o-phenylenediamines, which suggested the involvement of an isocyanate as intermediate, from which the final product is obtained by intramolecular nucleophilic addition (Scheme 18) [93]. 
<smiles>[R]Nc1cc[R1]cc1N</smiles>

$\left(\mathrm{R}^{1}=\mathrm{H}, \mathrm{Me}, \mathrm{Cl}, \mathrm{Br}, \mathrm{F}, \mathrm{CF}_{3}, \mathrm{NO}_{2}, \mathrm{CO}_{2} \mathrm{Et}, \mathrm{COPh} ; \mathrm{R}^{2}=\mathrm{H}, \mathrm{Ph}, \mathrm{Me}\right)$

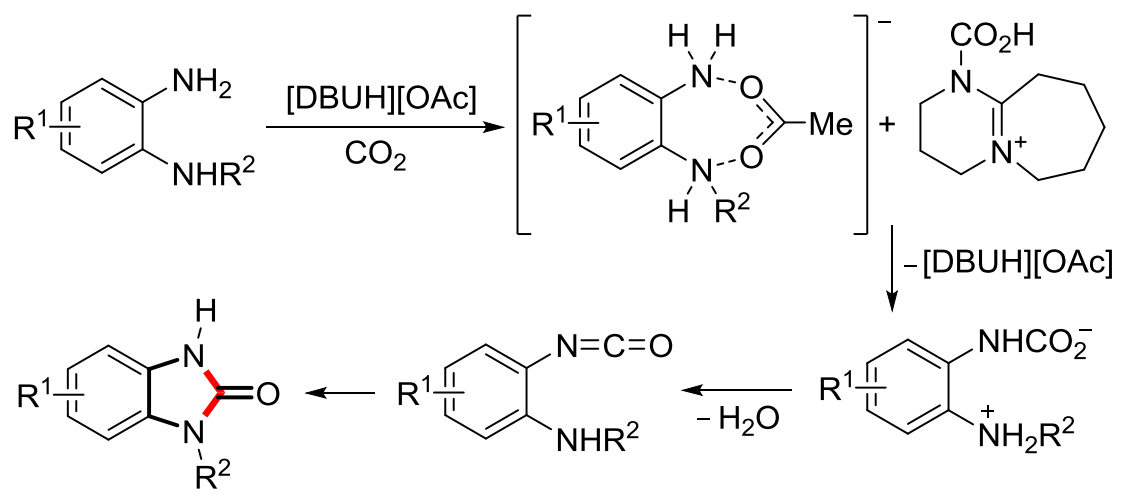

Scheme 18. Synthesis of benzimidazolidin-2-ones by carbonylation with $\mathrm{CO}_{2}$ using the ionic liquid [DBUH] [OAc] (DBUH = protonated 1,8-diazabicyclo[5.4.0]undec-7-ene, $\mathrm{OAc}=$ acetate anion) under solvent-free conditions [93].

More recently, the use of the ionic liquid $\left[\mathrm{Bu}_{4} \mathrm{P}\right][2-\mathrm{MIm}]$ (1,8-diazabicyclo[5.4.0]-7-undecenium 2-methylimidazolide) has allowed operation under the atmospheric pressure of $\mathrm{CO}_{2}$ for the conversion of several 1,2-benzenediamines into the corresponding benzimidazolidin-2-ones (Scheme 19) [94]. The proposed mechanism involves the formation of a carbamate species from the reaction between carbon dioxide and the anion of the ionic liquid, which is stabilized by the hydrogen bond interaction with the diamine. This is followed by the nucleophilic attack by the amino group, dehydration to give an isocyanate intermediate, and intramolecular nucleophilic attack by the second amino group to afford the cyclic urea (Scheme 19) [94].<smiles>Nc1c[R]ccc1N</smiles>

$(\mathrm{R}=\mathrm{H}, \mathrm{Me}, \mathrm{OMe}, \mathrm{Cl}, \mathrm{F})$

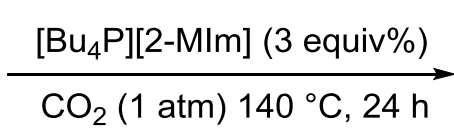<smiles>[R]#Cc1cccc2[nH]c(=O)[nH]c12</smiles>

$(52-95 \%)$

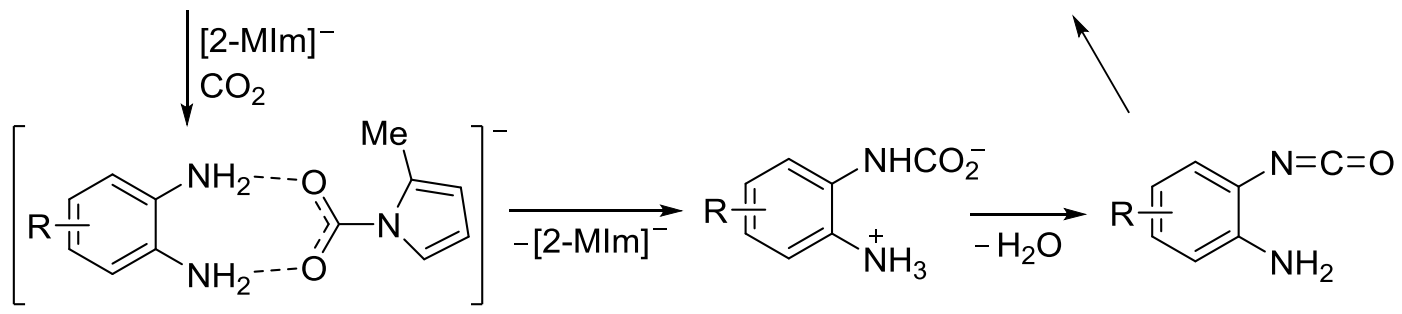

Scheme 19. Synthesis of benzimidazolidin-2-ones by carbonylation of 1,2-diaminobenzenes with atmospheric pressure $\mathrm{CO}_{2}$ [94].

Tungstate catalysts have also been successfully used for the synthesis of benzimidazolidin-2-ones from 1,2-benzenediamines (bearing primary amino groups) and low-pressure $\mathrm{CO}_{2}$. Reactions were carried out in NMP (NMP $=\mathrm{N}$-methylpyrrolidin-2-one) at $140{ }^{\circ} \mathrm{C}$ under one to $20 \mathrm{~atm}$ of $\mathrm{CO}_{2}$ for $24-96 \mathrm{~h}$ in the presence of $0.2-15 \mathrm{~mol} \%$ of catalyst, consisting of monomeric tungstate $\mathrm{TBA}_{2}\left[\mathrm{WO}_{4}\right]$ $(\mathrm{TBA}=$ tetrabutylammonium cation) (Scheme 20) $[95,96]$. The role of the catalyst was to activate both 
the diamine substrate and $\mathrm{CO}_{2}$, thus favoring the nucleophilic attack by the amino group to give a carbamate intermediate. Similarly to the mechanisms shown in previous Schemes 18 and 19, this intermediate then leads to the final product via dehydration to isocyanate followed by cyclization (Scheme 20) [96].
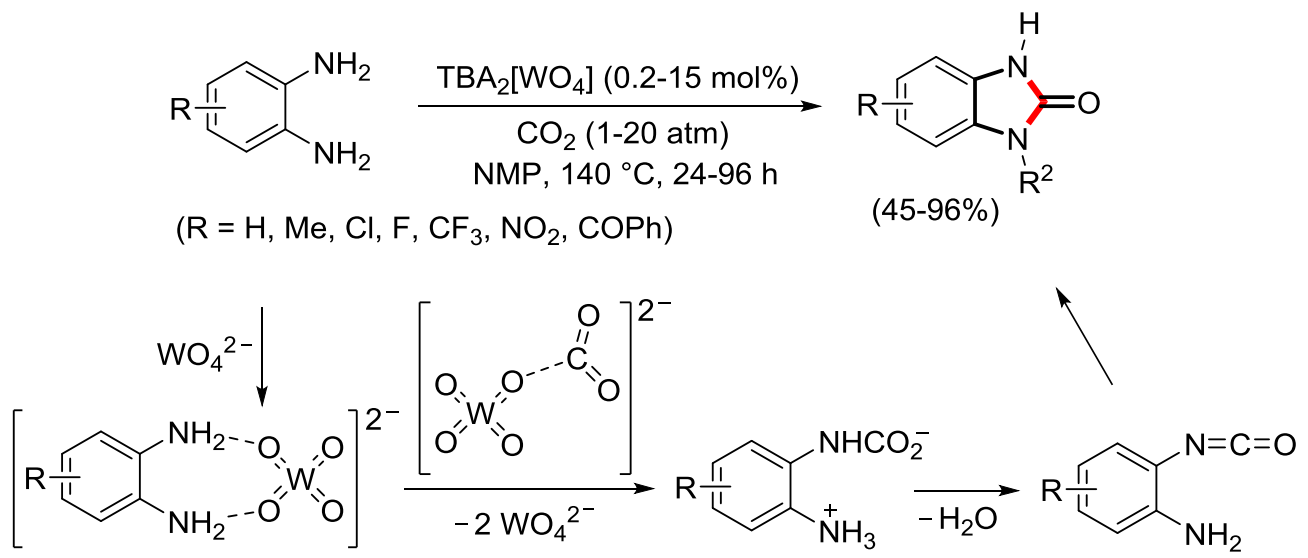

Scheme 20. Synthesis of benzimidazolidin-2-ones by carbonylation with $\mathrm{CO}_{2}$ using $\mathrm{TBA}_{2}\left[\mathrm{WO}_{4}\right](\mathrm{TBA}$ $=$ tetrabutylammonium cation) as catalyst $[95,96]$.

\section{Synthesis of 2-Imidazolidinones by Catalytic Diamination of Unsaturated C-C Bonds}

The metal-catalyzed diamination of unsaturated $\mathrm{C}-\mathrm{C}$ bonds is an elegant strategy to access imidazolidin-2-ones. In this context, various intramolecular and intermolecular diamination protocols have been developed using ureas or diaziridinones as the nitrogen source. Several enantioselective transformations have been successfully accomplished as well [97-100].

In general, the challenge in the development of catalytic diamination protocols is presumably due to the capability of diamines to coordinate almost every transition metal, which generates stable organometallic species that are not compatible with a catalytic process.

\subsection{Metal-Catalyzed Intramolecular Diamination of Alkenes with Ureas}

The metal-catalyzed intramolecular diamination of alkenes represents a very useful and exploited strategy for the construction of imidazolidin-2-one scaffold. The first report appeared in 2005, when Muñiz et al. disclosed a Pd(II)-catalyzed synthesis of 5-, 6- and 7-membered ring fused imidazolidin-2-ones (Scheme 21) [101].

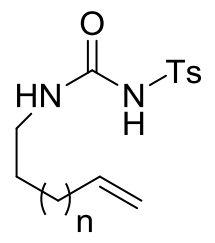

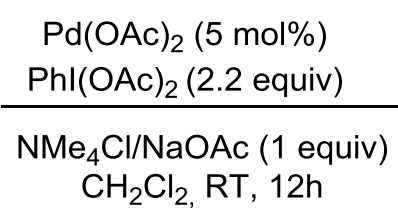<smiles>O=C1N([AsH3])CC2NCCN12</smiles>

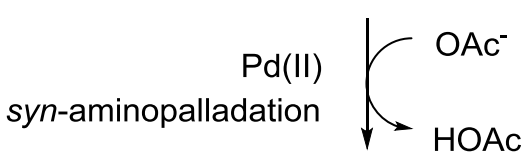

$\mathrm{n}=1,2,3$

$\checkmark \mathrm{HOAC}$

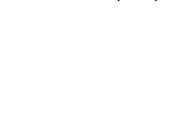

$\uparrow \uparrow$

amination-reductive elimination

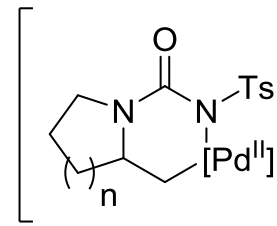

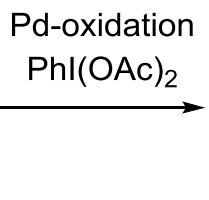

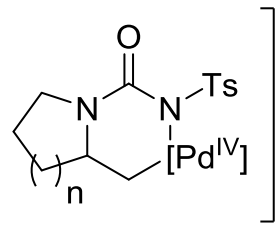

Scheme 21. Pd-catalyzed intramolecular diamination of unfunctionalized alkenes to five-membered, six-membered, and seven-membered ring fused imidazolidin-2-ones [101]. 
Excellent results were obtained only with the hypervalent iodine reagent $\mathrm{PhI}(\mathrm{OAc})_{2}$. A control experiment, with a stoichiometric amount of palladium without the use of the oxidant, did not give any trace of the expected product, suggesting the intermediacy of $\mathrm{Pd}(\mathrm{II})$ and $\mathrm{Pd}(\mathrm{IV})$ species. Under mild reaction conditions, privileged structures were conveniently synthesized with predictable stereochemistry, as revealed by deuterium labeling experiments. Later, detailed mechanistic studies led the authors to propose the formation of a $\mathrm{Pd}(\mathrm{IV})$ intermediate (Scheme 21) [102].

The use of the more environmentally benign copper(II) bromide as oxidant and the extension to internal alkenes, including acrylates, were further investigated by the same research group $[103,104]$.

In the same years, Muñiz et al. demonstrated that nickel catalysts are highly active in this transformation as well, providing an attractive alternative in terms of catalyst cost and reaction scope [105]. Furthermore, the same author broadened the catalyst scope for the diamination of alkenes by introducing a homogeneous gold(I) catalyst [106].

In 2012, Muñiz et al. reported an impressive metal-free intramolecular diamination of alkenes based on the use of potassium bromide as the catalyst and sodium chlorite as terminal oxidant (Scheme 22) $[107,108]$. This halide catalysis features general applicability, readily available reagents and catalysts, and can be successfully scaled up.
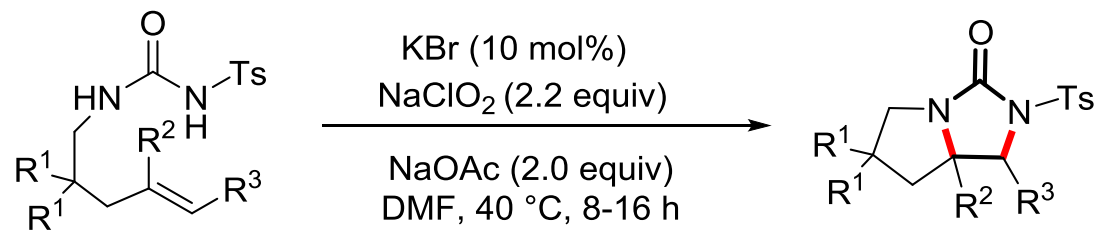

Scheme 22. Metal-free Br-catalyzed intramolecular diamination of alkenes to highly functionalized bicyclic imidazolidin-2-ones [107,108].

A rare example of $\mathrm{Cu}$ (II)-catalyzed asymmetric intramolecular cyclization of $\mathrm{N}$-alkenyl ureas to access chiral imidazolidinones in moderate to good yields with high to excellent enantioselectivity was recently reported by Fu et al. (Scheme 23) [109]. The bidentate oxazoline ligand L1 was found to be the ligand of choice in order to achieve high enantioselectivities. The basic medium was also essential to impart chirality to the final product.

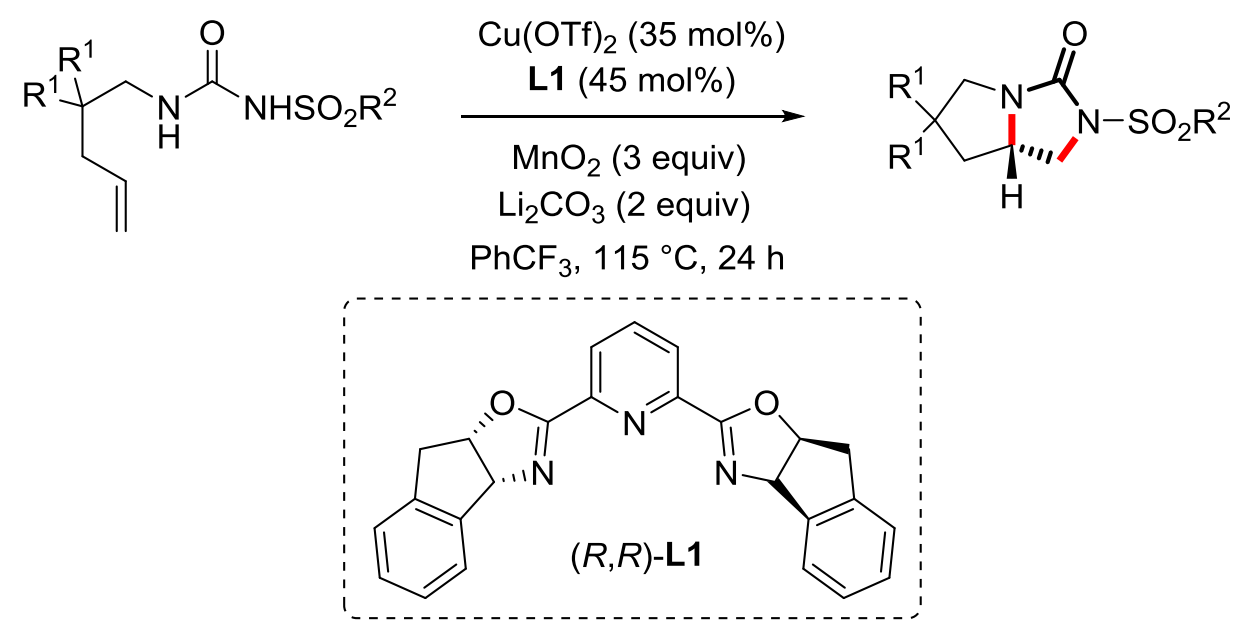

Scheme 23. $\mathrm{Cu}(\mathrm{OTf})_{2}-(R, R)$-L1-catalyzed intramolecular diamination of $\mathrm{N}$-alkenyl ureas to chiral imidazolidinones [109]. 


\subsection{Metal-Catalyzed Intramolecular Diamination of Allenes with Ureas}

Allene-tethered ureas were successfully converted to bicyclic imidazolidin-2-ones in high yield and diastereomeric purity by means of a catalytic 1:1 mixture of $\mathrm{Au}(\mathrm{I})-\mathrm{N}$-heterocyclic carbene complex and $\mathrm{AgPF}_{6}$ under mild reaction conditions (Scheme 24) [110].<smiles>C=CCCC(CNC(=O)NBr)(c1ccccc1)c1ccccc1</smiles>

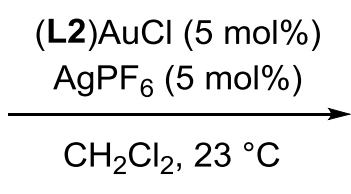<smiles>O=C1N([Al])[CH]C2CCC(c3ccccc3)(c3ccccc3)CN12</smiles><smiles>CC(C)c1cccc(C(F)(F)F)c1-n1ccnc1-c1cccc(C(F)(F)F)c1</smiles>

Scheme 24. $\mathrm{Au}(\mathrm{I})$-catalyzed intramolecular dihydroamination of allenes to bicyclic imidazolidin-2-ones [110].

This redox-neutral and atom-economic approach does not need stoichiometric oxidant and would provide an alternative to alkene diamination for the synthesis of five-membered ureas.

\subsection{Metal-Catalyzed Intramolecular Diamination of Alkynes with Ureas}

A rare example of intramolecular 1,2-diamination of alkynes for the synthesis of indole-imidazolidinone fused derivatives, has been recently reported by Reddy et al. [6]. Control experiments revealed that urea derivatives, which were likely generated in situ from aminophenyl propargyl alcohols and isocyanates, undergo a $\mathrm{Ag}(\mathrm{I})$-catalyzed sequential vicinal diamination featuring a double cyclization process followed by 1,3-allylic amino dehydroxylation step (Scheme 25).<smiles>[R]C(C)(C)c1ccccc1N</smiles>

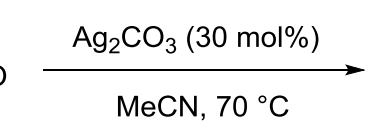<smiles>[R]c1c2n(c(=O)n1[R])C([R])N([R])C2</smiles><smiles>[R]C#CC([R])(O)c1ccccc1NC(=O)N[R]</smiles><smiles>CC</smiles><smiles>[R]CNC(=O)N1C(=C([R])CN)C([R17])(O)c2ccccc21</smiles>

Scheme 25. Ag-catalyzed intramolecular diamination of alkynes to fused indole-imidazolidinone derivatives [6].

\subsection{Metal-Catalyzed Intermolecular Diamination of Dienes with Ureas}

The $\mathrm{Pd}(\mathrm{II})$-catalyzed intermolecular diamination of conjugated dienes with dialkyl ureas was firstly reported by Lloyd-Jones and Booker-Milburn in 2005 [111]. This non-asymmetric transformation was carried out without additional ligands, and led to vinyl imidazolidinones in good to excellent yields. Very recently, a highly efficient synthesis of chiral imidazolidin-2-ones 
through the Pd(II)catalyzed diamination of 1,3-dienes with 1,3-dialkylureas has been reported by Gong and Han (Scheme 26) [112].<smiles>[R]C=CC=[C-]</smiles>

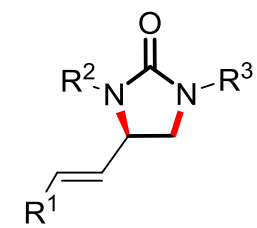

up to $99 \%$ yield up to $97 \%$ ee

Scheme 26. Pd-catalyzed intermolecular asymmetric diamination of 1,3-dienes to chiral imidazolidin-2-ones [112].

High yields and excellent enantioselectivities were achieved under mild reaction conditions by means of a chiral pyridine-oxazoline ligand. The choice of the oxidant was also crucial, since 2,5-dimethoxybenzoquinone (2,5-DMBQ) gave the best reaction performance, compared to $B Q$, chloranil, and oxygen. Molecular sieves were found to improve both the yield and enantioselectivity values. Notably, as for the non-asymmetric transformation [111], this enantioselective diamination reaction involves exclusively the terminal $\mathrm{C}=\mathrm{C}$ double bond of 1,3-dienes, and for this, it is highly complementary to the asymmetric Shi's protocol [113], which mainly occurs at the internal double bond (Scheme 29).

\subsection{Metal-Catalyzed Intermolecular Diamination of Alkenes with Diaziridinones}

Shi et al. discovered that $\mathrm{Pd}(0)$ and $\mathrm{Cu}(\mathrm{I})$ were highly effective catalysts for the stereoselective diamination of olefins, dienes, and trienes with di-tert-butyldiaziridinone as a nitrogen source [97]. This strategy relies on the $\mathrm{N}-\mathrm{N}$ bond activation by means of metal species in their low oxidation state, as depicted in Scheme 27. A metal can oxidatively add to the $\mathrm{N}-\mathrm{N}$ bond of dialkyldiaziridinone, providing a four-membered metallacycle $\mathbf{I}$. This intermediate could react with an alkene through migratory insertion and subsequent reductive elimination, leading to the diamination product (imidazolidinone derivative) and the active catalytic species.

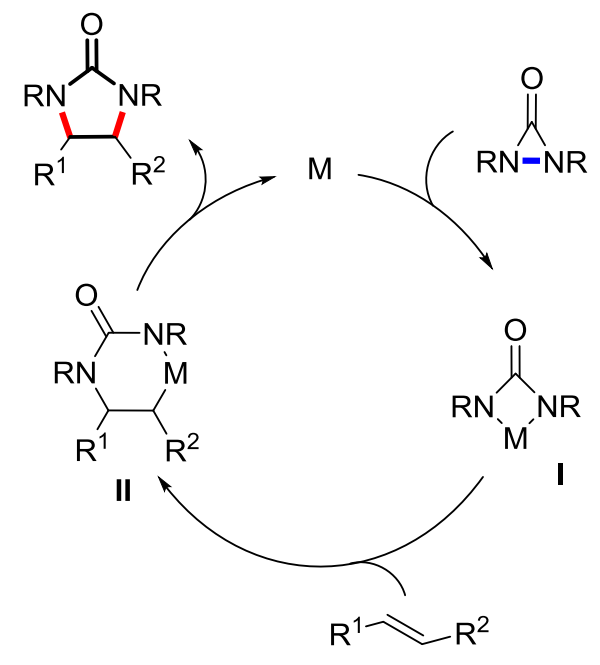

Scheme 27. Metal-catalyzed intermolecular diamination of olefins to imidazolidin-2-ones [97]. 
In a first report, Shi demonstrated that conjugated dienes can be regioselectively and stereoselectively diaminated under palladium catalysis using di-tert-butylaziridinone as a nitrogen source (Scheme 28) [114]. Notably, diamination occurred exclusively at the internal double bond. When trienes were employed, only the middle double bond was involved.<smiles>[R]C=C([R])C([R])=C[NH2+][CH]</smiles><smiles>CC(C)(C)N1C(=O)N1C(C)(C)C</smiles><smiles>O=[PH](=O)(O)O[Mg]</smiles><smiles>[R]C(=C)[C@]1([R])C([R])N(C(C)(C)C)C(=O)N1C([R])(C)C</smiles>

Scheme 28. Pd(0)-catalyzed intermolecular diamination of dienes to imidazolidin-2-ones [114].

The symmetric four-membered Pd(II) intermediate, which is analogous to I (Scheme 27), was detected by ${ }^{1} \mathrm{H}$ NMR spectroscopy, starting from $\mathrm{Pd}\left(\mathrm{PPh}_{3}\right)_{4}$, di-tert-butyldiaziridinone and (E)-1-phenylbutadiene [115].

An asymmetric version of this diamination process was subsequently disclosed. (E)-1,3-Hexadiene and di-tert-butyldiaziridinone were used as model substrates, while $\operatorname{Pd}_{2}(\mathrm{dba})_{3}$ and several chiral ligands were examined (Scheme 29) [113]. The choice of the ligand was critical in order to achieve high conversion and enantioselectivity. A BINOL-based chiral phosphorus amidite ligand (L4), containing a sterically bulky tetramethylpiperidine, was found to give the best reaction outcome. With the optimal reaction conditions, a variety of conjugated dienes were regioselectively diaminated at the internal double bond in good yields and high enantioselectivities (up to $95 \%$ ee).

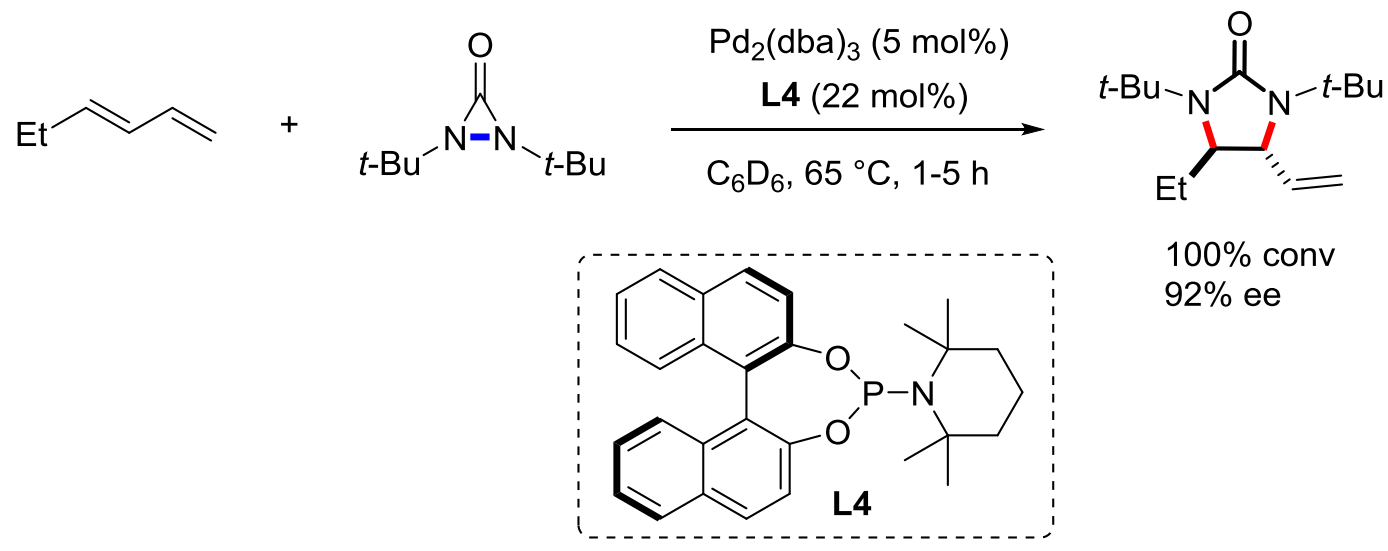

Scheme 29. $\operatorname{Pd}(0)$-catalyzed asymmetric intermolecular diamination of (E)-1,3-hexadiene [113].

Further studies demonstrated that $N$-heterocyclic carbene-Pd(0) complexes were also efficient catalysts to access vinyl imidazolidinones [116]. However, limited enentioselectivities (62-78\% ee) were achieved when chiral carbene ligands were employed [117].

Interestingly, under solvent-free conditions, the diamination occurred at allylic and homoallylic carbons rather than at the double bond when terminal olefins were treated with $\mathrm{Pd}\left(\mathrm{PPh}_{3}\right)_{4}$ and di-tert-butyldiaziridinone (Scheme 30) [118].

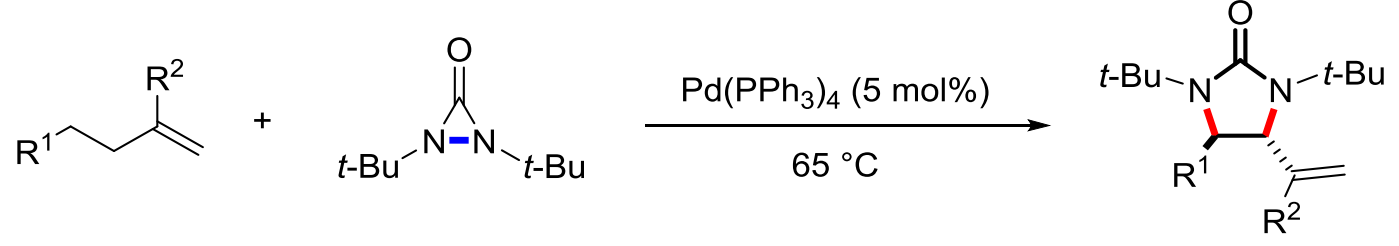

Scheme 30. $\operatorname{Pd}(0)$-catalyzed intermolecular diamination of terminal olefins [118]. 
In this case, the process likely proceeds through the in situ formation of a diene intermediate by palladium catalysis. Remarkably, substrates bearing two terminal double bonds underwent bisdiamination successfully.

A catalytic asymmetric process was also achieved in the presence of $\operatorname{Pd}_{2}(\mathrm{dba})_{3}$ and a chiral BINOL-derived phosphorus amidite ligand (L5) (Scheme 31) [119]. A broad range of chiral imidazolidinones were obtained from terminal alkenes and di-tert-butyldiaziridinone with good yields and high enantioselectivities.

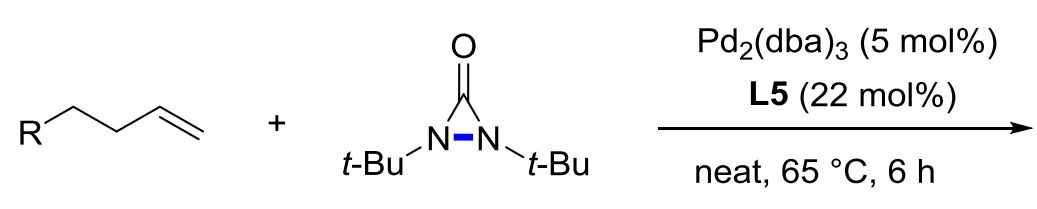<smiles>[R]C1[C@H](C=C)N(C(C)(C)C)C(=O)N1C(C)(C)C</smiles><smiles></smiles>

Scheme 31. $\operatorname{Pd}(0)$-catalyzed asymmetric intermolecular diamination of olefins [119].

Importantly, the potent P receptor antagonist (+)-CP-99,994 was synthesized in $20 \%$ overall yield and $>99 \%$ ee from readily available 4-phenyl-1-butene [120].

More recently, spirocyclic indolines containing imidazolidinone scaffold were synthesized in good yields through a novel sequential allylic and aromatic $\mathrm{C}-\mathrm{H}$ amination process starting from $\alpha$-methylstyrenes, di-tert-butyldiaziridinone and $\mathrm{Pd}\left(\mathrm{PPh}_{3}\right)_{4}$, as the catalyst (Scheme 32). [121] Remarkably, four $\mathrm{C}-\mathrm{N}$ bonds and one spiro quaternary carbon were generated in a single operation.
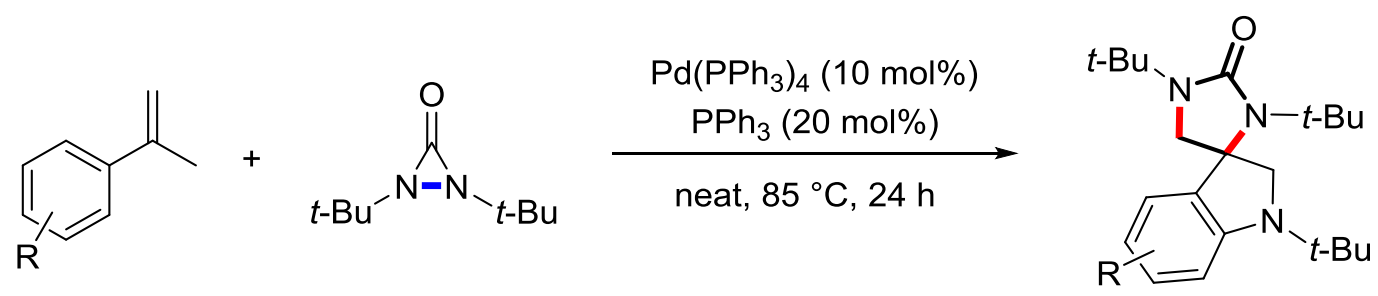

Scheme 32. $\operatorname{Pd}(0)$-catalyzed intermolecular diamination of $\alpha$-methylstyrenes to spirocyclic indolines [121].

A variety of conjugated dienes and a triene can be effectively diaminated in good yields with $\mathrm{CuCl}-\mathrm{P}(\mathrm{OPh})_{3}$ and di-tert-butyldiaziridinone under mild reaction conditions (Scheme 33) [122].<smiles>[R]C(=C)C([R])=C[CH-]</smiles><smiles>CC(C)(C)N1C(=O)N1C(C)(C)C</smiles>

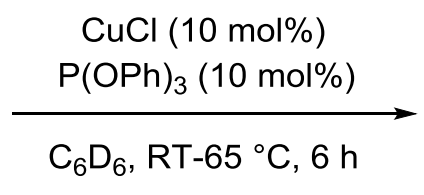<smiles>[R]/C=C(\[R])[C@]1([R])CN(C(C)(C)C)C(=O)N1C(C)(C)C</smiles>

Scheme 33. $\mathrm{CuCl} / \mathrm{P}(\mathrm{OPh})_{3}$-catalyzed intermolecular diamination of dienes to vinyl imidazolidinones [122].

Unlike the $\mathrm{Pd}(0)$-catalyzed process (Scheme 28), the $\mathrm{Cu}(\mathrm{I})$-catalyzed diamination occurred mostly at the terminal double bond of dienes with generally high regioselectivities. The diamination reaction 
likely proceeds via a radical mechanism, which is mechanistically distinct from the $\mathrm{Pd}(0)$-catalyzed process. Trienes were conveniently converted to corresponding diene-tethered imidazolidinones as well. Later, the $\mathrm{Cu}(\mathrm{I})$-catalyzed asymmetric diamination has been found to be feasible [123].

As reported by Shi in 2010, the regioselectivity for the $\mathrm{Cu}(\mathrm{I})$-catalyzed diamination of dienes with di-tert-butyldiaziridinone can be controlled by a careful manipulation of the reaction conditions (Scheme 34) [124]. In this work, various conjugated dienes can be efficiently diaminated at the internal double bond with $\mathrm{CuBr}$, giving the corresponding imidazolidinones in high yields and regioselectivities.

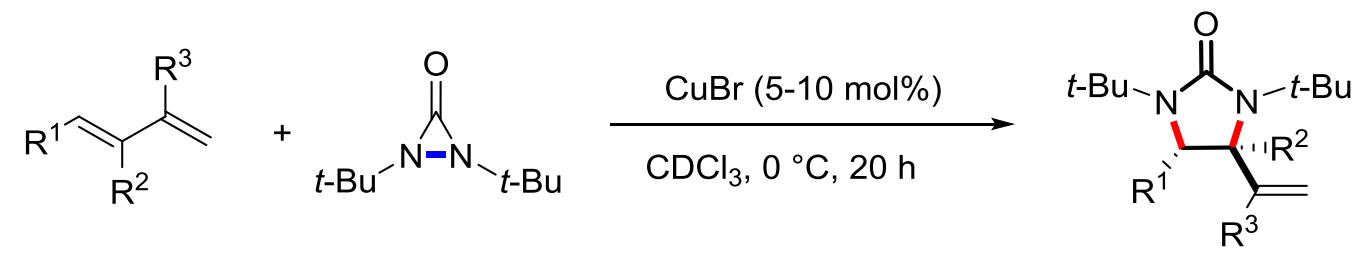

Scheme 34. CuBr-catalyzed intermolecular diamination of dienes to vinyl imidazolidinones [124].

Two distinct mechanistic pathways, involving $\mathrm{Cu}(\mathrm{II})$ and $\mathrm{Cu}(\mathrm{III})$ species, were proposed for this remarkable reactivity [125].

Terminal olefins can be also efficiently diaminated with di-tert-butyldiaziridinone to imidazolidinones in the presence of $\mathrm{CuCl}-\mathrm{PPh}_{3}$ [126]. As shown in Scheme 35, a variety of 1,1-disubstituted terminal olefins were readily diaminated, affording the corresponding 4,4-disubstituted imidazolidin-2-ones in good yields.

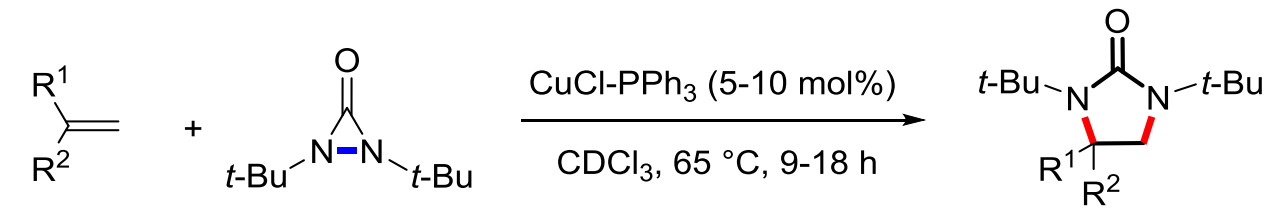

Scheme 35. CuCl-PPh -catalyzed intermolecular diamination of 1,1-disubstituted terminal olefins to 4,4-disubstituted imidazolidinones [126].

\section{Synthesis of 2-Imidazolidinone Derivatives by Catalytic Hydroamination of Unsaturated Ureas}

The $\mathrm{N}$-hydroamination reaction represents a robust methodology for the construction of $\mathrm{C}-\mathrm{N}$ bonds [127-129]. This approach consists in the nucleophilic addition of a nitrogen on a C-C unsaturated bond, and it involves the cleavage of an $\mathrm{N}-\mathrm{H}$ bond with the formation of $\mathrm{C}-\mathrm{N}$ and $\mathrm{C}-\mathrm{H}$ bonds. From the thermodynamic point of view, this reaction is slightly exothermic; on the other hand, the kinetic is unfavorable due to the presence of the nucleophile electron density and the $\pi$-electrons of the C-C unsaturated bond $[130,131]$. Hence, a great amount of energy has to be provided to the system in order to overcome the high activation barrier. To solve this issue, both a strong acid $[132,133]$ or a base [134-136] can be employed. The first one protonates the double or triple bond, generating a carbocation that is more prone to undergo a nucleophilic attack, while a strong base is required to deprotonate the nitrogen and create a stronger nucleophile. Metal catalysts [137-142] can coordinate the unsaturated bond, subtracting electronic density or replacing the hydrogen in the $\mathrm{N}-\mathrm{H}$ bond. Indeed the nature of the nucleophile greatly affects the required reaction conditions. Amides and related compounds, such as ureas, carbamates, and amidines possess less nucleophilic nitrogen due to the presence of diverse resonance structures. When these compounds are engaged in an $\mathrm{N}$-hydroamination reaction, harsher reaction conditions are expected.

In this context, propargylic and allylic ureas are relevant substrates allowing the formation, after intramolecular 5-exo-dig $\mathrm{N}$-hydroamination, of biological active 2-imidazolidinones. 


\subsection{Intramolecular N-hydroamination of Propargylic Ureas}

Propargylic ureas, under appropriate reaction conditions, can result in different cyclization pathways. In order to allow the construction of five-member cyclic ureas via 5-exo-dig cyclization and thus promote the formation of imidazolidin-2-ones, a tailored catalytic methodology is crucial [143]. Based on his previous observations [144], Van der Eycken et al. reported two different metal catalyzed complementary protocols [145] for the cyclization of in situ generated propargylic ureas (Scheme 36). A cationic gold (I) catalysis based on $\mathrm{AuPPh}_{3} \mathrm{Cl} / \mathrm{AgOTf}$ system promotes the $\mathrm{O}$-cyclization, while AgOTf-catalyzed reactions allow the formation of imidazolidin-2-ones through an $\mathrm{N}$-cyclization. The authors proposed an explanation for the observed chemoselectivity based on the Pearson's concept HSAB (hard and soft acids and bases). The mechanism involves the coordination of silver to the triple bond. This type of coordination facilitates the hydroamination step through a trans-amidometallation that results in the formation of a five-member ring bearing an exocyclic double bond. Finally, a proton demetallation leads to the formation of the desired product with a retention of configuration (Z-alkene).

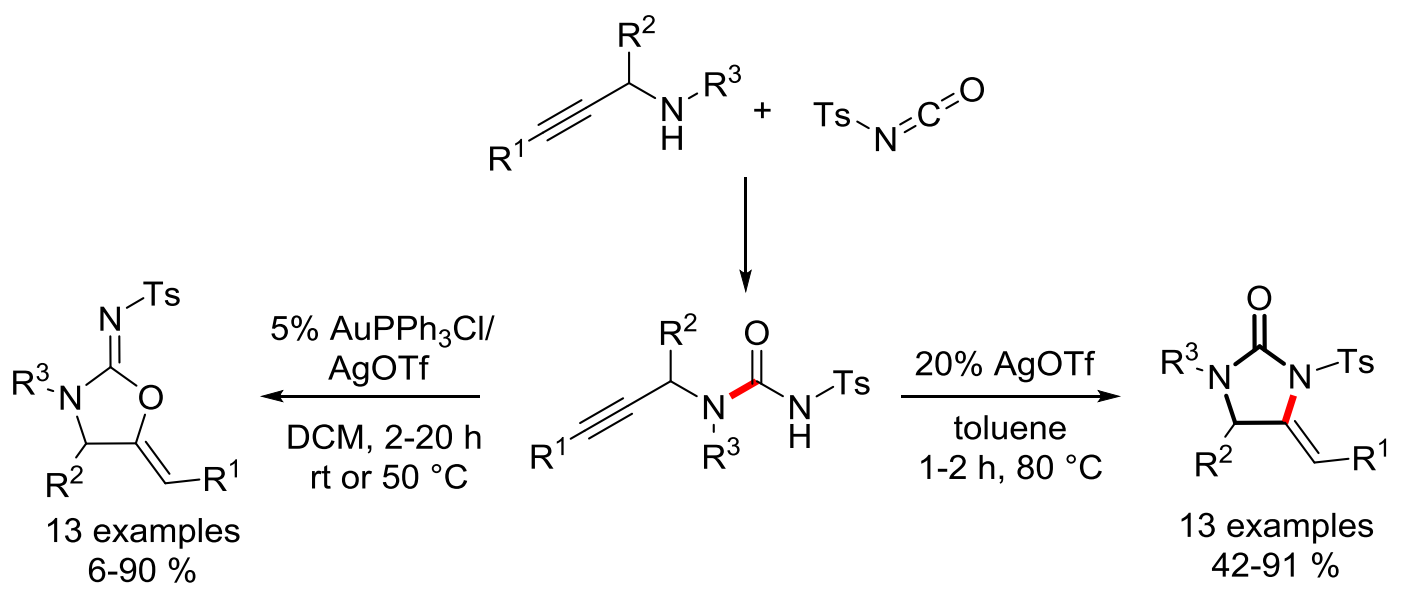

Scheme 36. $\mathrm{Ag}(\mathrm{I})$-catalyzed hydroamination of propargylic ureas formed in situ from propargylic amines and tosyl isocyanate [145].

In 2016 Testero and Krchňák observed a remarkable selectivity using gold catalysis when acyclic propargyl ureas were employed as starting materials [146]. An efficient and selective 5-exo-dig cyclization reaction occurred under solid-phase organic synthesis (Scheme 37). Under mild conditions, propargyl ureas anchored on a solid support were efficiently converted into imidazolidinones. This protocol features the use of $\mathrm{AuCl}$ as catalyst (5 mol\%) and the mixture $\mathrm{DCM} / \mathrm{MeCN}(5: 1)$ as solvent. Subsequent treatment with TFA (TFA = trifluoroacetic acid) afforded a mixture of imidazolidinones and imidazolones.

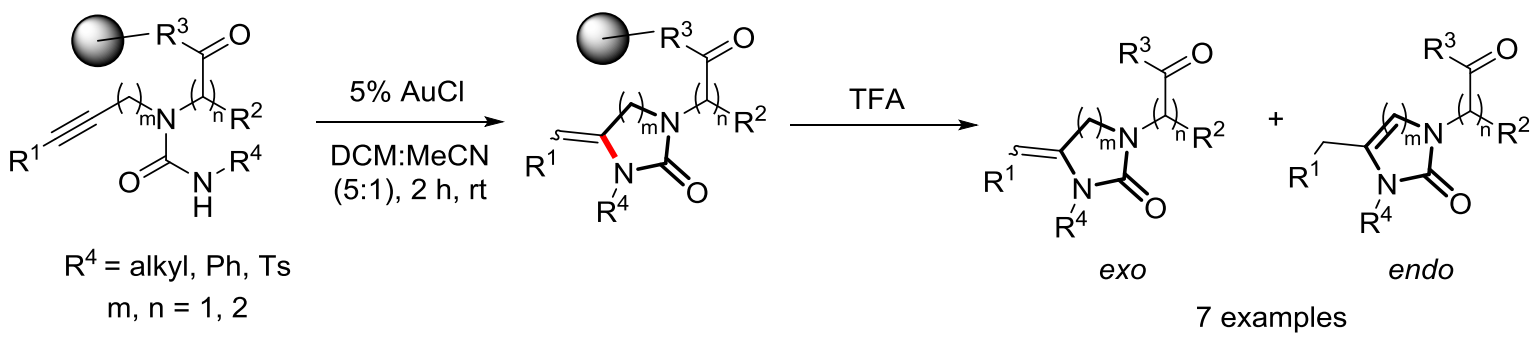

Scheme 37. Gold catalysis for the solid phase synthesis of imidazolidin-2-ones [146].

Over the years, palladium has captured chemists' attention also for hydroamination reactions. Bäckvall et al. proposed a palladium-catalyzed strategy for the $N$-cyclization of propargylic carbam(othio)ates or propargylic (thio)ureas for the construction of five-member heterocycles [147]. Propargylic carbamates underwent an efficient hydroamination process using $\mathrm{Pd}(\mathrm{OAc})_{2}$ and 
$n-\mathrm{Bu}_{4} \mathrm{NOAc}$ in DCE as the solvent. Similar conditions were successfully employed for the selective 5-exo-dig cyclization of propargylic tosylureas (Scheme 38). The mechanism is similar to the previously described one for silver-promoted $N$-cyclization [145].

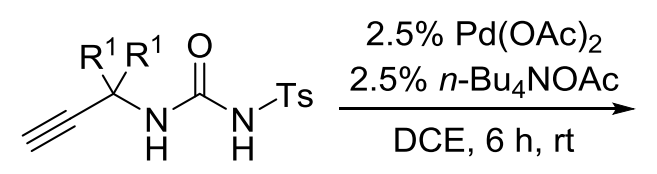<smiles>[R7]C1NC(=O)N([AsH-])C1=C</smiles>

Scheme 38. Pd-catalyzed hydroamination of propargylic tosylureas [147].

In 2006, Lu et al. reported an innovative approach for the synthesis of polycyclic indoles from propargylic ureas [148]. They initially proposed a mechanism involving a syn amidopalladation of the acetylene moiety as a key step, with the formation of an imidazolidin-2-one ring. In 2010, they published an update with further studies on the mechanism [149]. According to this last report, the first step consists in the hydroamination promoted by $\mathrm{K}_{2} \mathrm{CO}_{3}$ at high temperature, followed by a palladium-catalyzed annulation (Scheme 39).

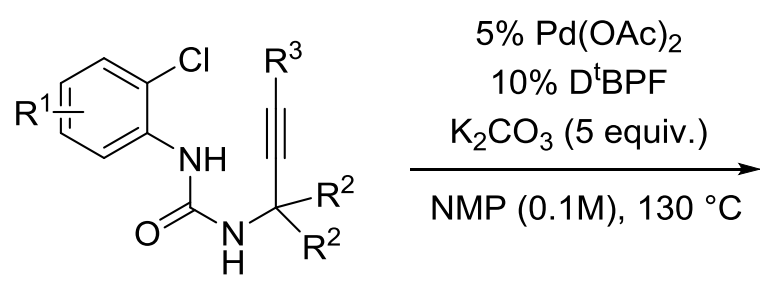<smiles>[R]c1c2n(c3c1=CC#[R1]=CC=3)C([R])C([R])NC2=O</smiles>
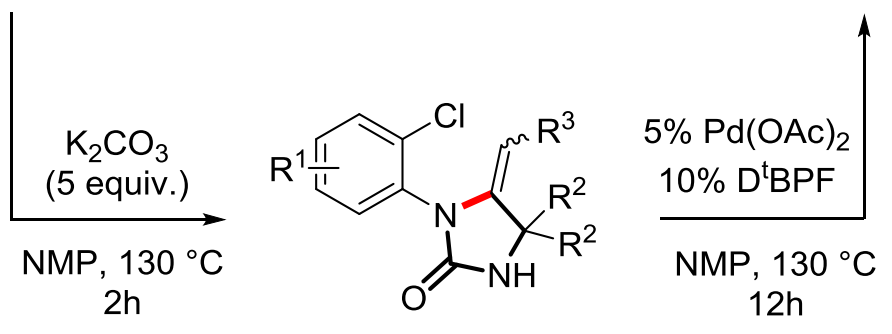

Scheme 39. Base-promoted hydroamination followed by Pd-catalyzed heteroannulation to condensed indole-imidazolidin-2-one derivatives [149].

Another example of base-mediated hydroamination for the synthesis of imidazolidin-2-ones was reported by Lubell [150]. The 5-exo-dig cyclization of azapropargyl glicinamides was enabled by 2.5 equivalents of sodium hydride. Also, $\mathrm{NaOH}$ can trigger the hydroamination of propargyl(thio)ureas to afford five-member cyclic (thio)ureas [151]. The base was used as the promoter, and it provided yields up to $97 \%$ in two hours of reaction time. In 2014, Huguenot exploited the potential of TBAF (TBAF $=$ tetra- $n$-butylammonium fluoride) as the stoichiometric promoter for the above-mentioned cyclization [152]. An environmentally benign approach was disclosed by Hill in 2014 using non-toxic bis-amide alkaline earth complexes [153]. Diverse propargylamidine derivatives were successfully coupled with a range of isocyanates to afford propargylic ureas that were then cyclized to imidazolidin-2-ones (Scheme 40). The mechanism involves the formation of acyclic ureas; then, the intramolecular hydroamination step leads to the construction of the five-member cyclic urea. A similar approach was reported in 2017, replacing alkaline earth catalysis with zinc [154]. 


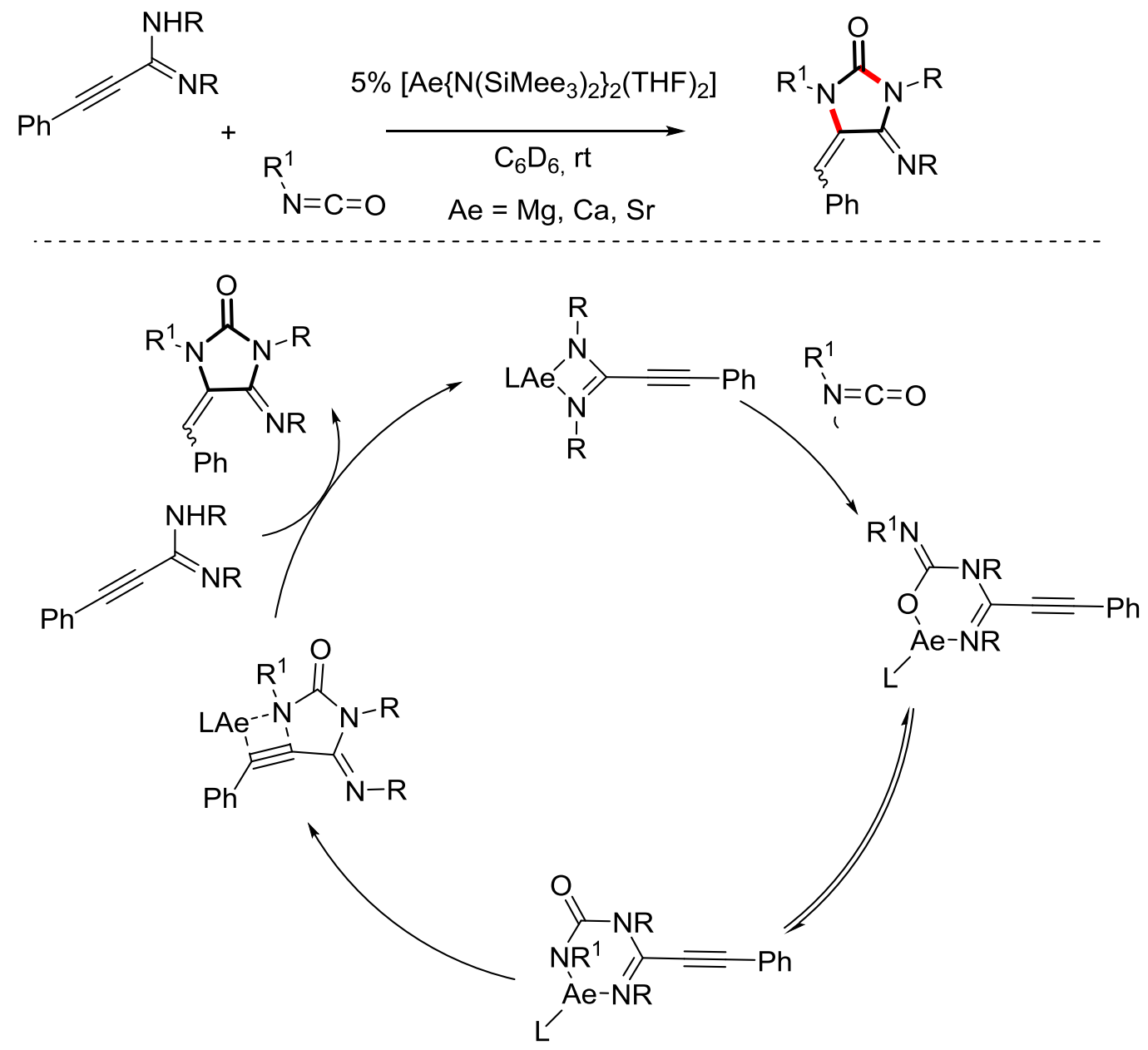

Scheme 40. Alkaline earth catalysis for the synthesis of imidazolidin-2-one derivatives [153].

\subsection{Intramolecular N-hydroamination of Allylic Ureas}

The formation of a $\mathrm{C}-\mathrm{N}$ bond through the hydroamination of a $\mathrm{C}-\mathrm{C}$ double bond is more challenging than the hydroamination of a triple bond, due to its diminished electron density and thus its lower reactivity. Palladium was found to be a suitable candidate by Wolfe et al., who deeply studied this transformation. In 2006, they published a new synthetic strategy for the synthesis of imidazolidin-2-ones by a palladium-catalyzed carboamination from allylic ureas and aryl bromides [155]. They managed to obtain several products from both terminal and internal double bonds. The latter case led to the formation of the syn isomer in a good diastereomeric excess.

The proposed mechanism (Scheme 41) involves first an oxidative addition of the aryl bromides to $\mathrm{Pd}(0)$; then, after deprotonation of the urea moiety by $\mathrm{NaOtBu}$, a $\mathrm{Pd}-\mathrm{N}$ bond could be formed. The syn insertion of the alkene into the $\mathrm{Pd}-\mathrm{N}$ bond, followed by reductive elimination, affords the desired imidazolidin-2-one. A few years later, Wolfe et al. further investigated this methodology [156], providing a larger reaction scope and additional mechanistic findings. A catalytic asymmetric access to enantiomerically enriched imidazolidin-2-ones was disclosed by the same research group in 2012 (Scheme 42) [157]. Experimental findings showed that the reductive elimination can be the enantio-determining step. Indeed, they found a strong correlation between the nucleophilicity of the nitrogen involved in the cyclization and the resulting asymmetric induction. A less nucleophilic nitrogen leads to an increase in the enantiomeric excess and a loss in reactivity, which are both due to the less-favored final reductive elimination. 


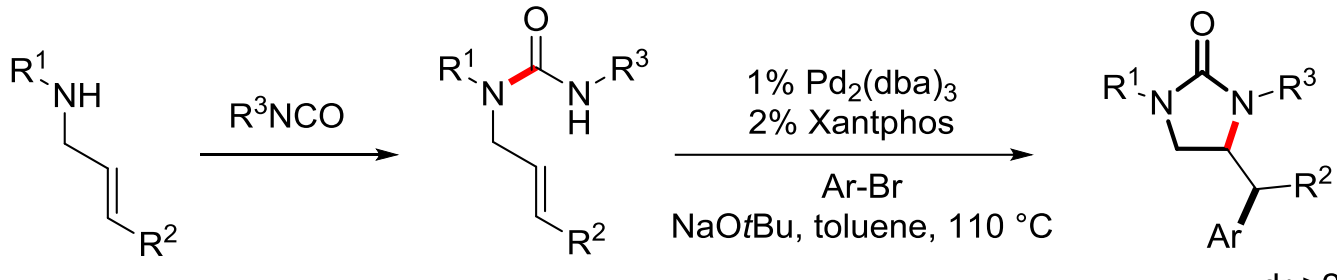

$\mathrm{dr}>20: 1$

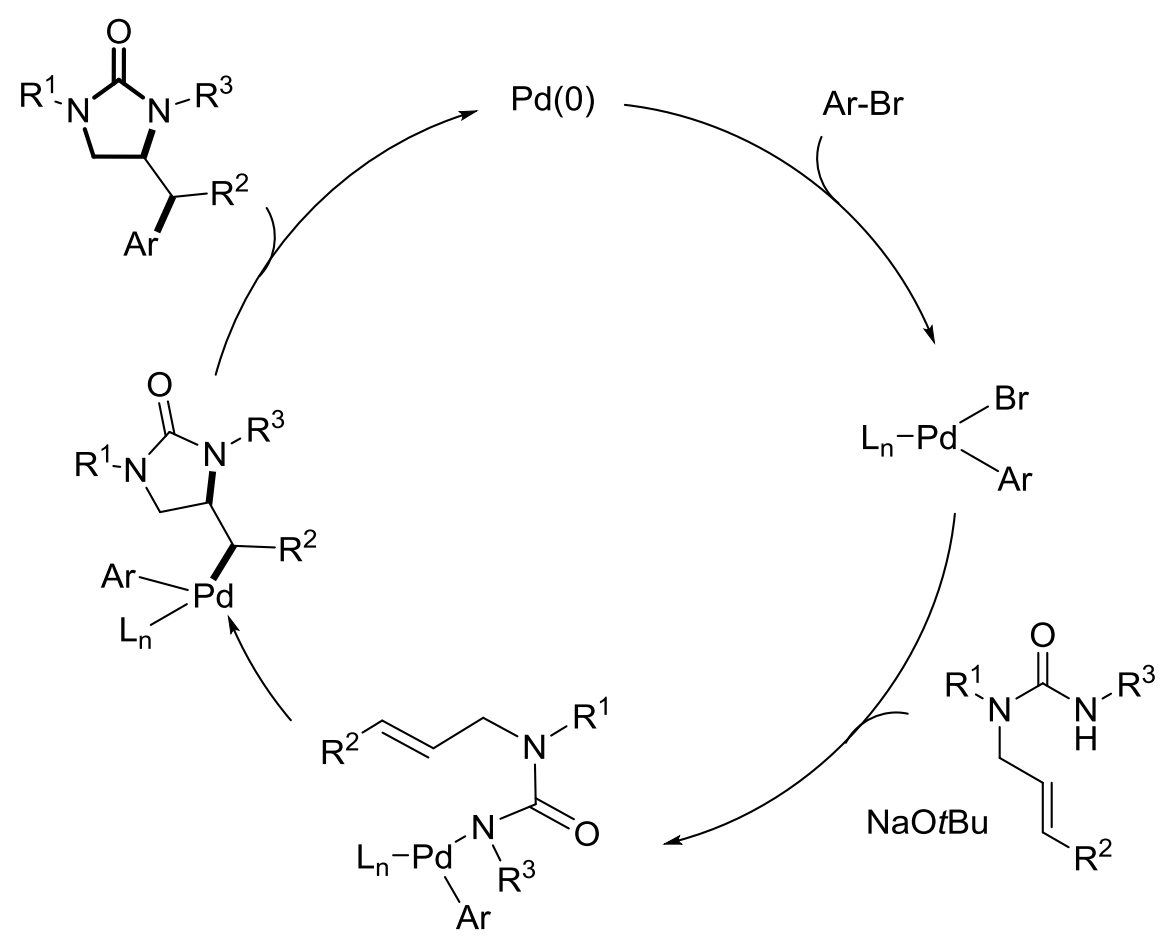

Scheme 41. Pd-catalyzed syn carboamination of allylureas [155].

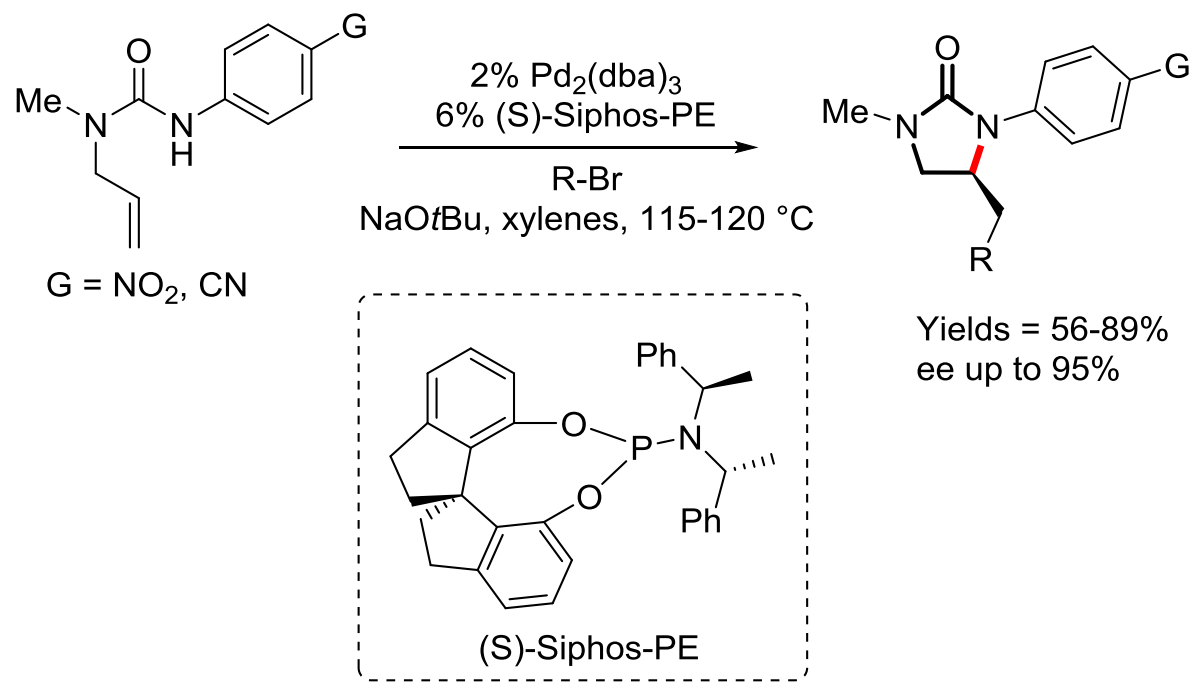

Scheme 42. Pd-catalyzed asymmetric carboamination of allylureas [157].

Taking advantage from these pioneering studies, Lin et al. designed and synthesized a new chiral spiro phosphoramidite ligand for the asymmetric synthesis of imidazolidin-2-one derivatives from $\mathrm{N}$-allyl ureas (Scheme 43) [158]. They also noticed a remarkable effect on the asymmetric induction 
due to the nucleophilicity of the urea nitrogen. Using electron-withdrawing groups, they efficiently obtained high enantiomeric excesses.<smiles>[X]c1ccc(NC(=O)N(C)CC=C)cc1</smiles>

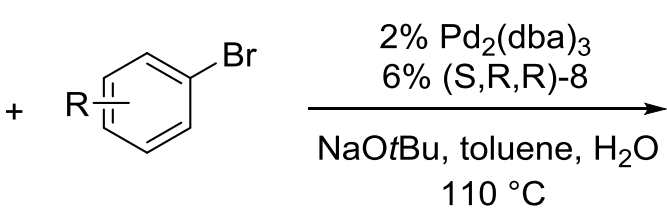<smiles>[R]c1ccc(N2C(=O)N(C)CC2Cc2cccc([X])c2)cc1</smiles>

Yields $=62-94 \%$

$\mathrm{X}=\mathrm{CN}, \mathrm{NO}_{2}$ ee up to $93 \%$

$\mathrm{X}=\mathrm{OMe}, \mathrm{H}$ ee $53-66 \%$

Scheme 43. New chiral ligand for the asymmetric carboamination of allylic ureas [158].

Very recently, Wolfe et al. reported a palladium-catalyzed diamination of alkenes from $\mathrm{N}$-allyl ureas (Scheme 44) [159]. The first amination step is responsible for the construction of the imidazolidin-2-one scaffold by trans-aminopalladation of the alkene moiety. The latter amination step involves the formation of a $\mathrm{Csp}^{3}-\mathrm{Nsp}^{3}$ bond after reductive elimination from an alkylpalladium complex. The use of the JackiePhos ligand proved to be fundamental for the last step of reductive elimination due to its bulkiness and electron-poor character.<smiles>[X]c1ccc(NC(=O)N(Cc2ccccc2)C([R])C=C)cc1</smiles>

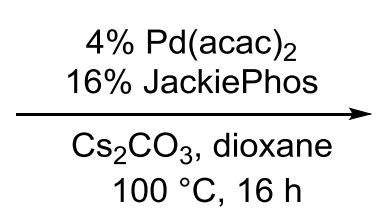<smiles>[X]c1ccc(N2CCCN(C[C@H]3NC(=O)N(Cc4ccccc4)[C@@H]3[R])C2)cc1</smiles>

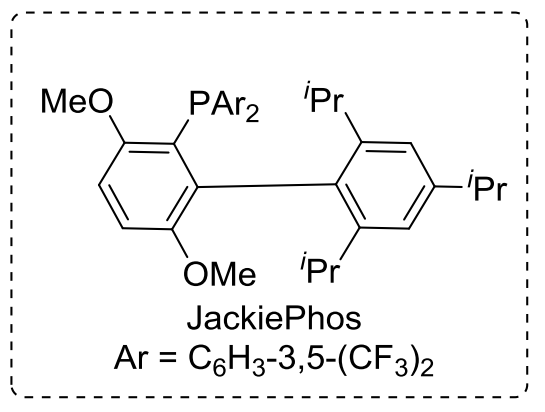

Yields $=14-90 \%$ 6 examples

Scheme 44. Diamination of $N$-allyl ureas [159].

A copper-mediated strategy to synthesize imidazolidin-2-ones through a diamination process of $\mathrm{N}$-allylic ureas was previously reported by Chemler [160,161]. A stoichiometric amount of copper was required in order to minimize by-product formation. The mechanism involves a first step of copper-mediated hydroamination that leads to the formation of an unstable organocopper (II) intermediate. This species undergoes the homolitic cleavage of the $\mathrm{C}-\mathrm{Cu}$ bond to form a transient radical on a primary carbon that reacts with an external nitrogen nucleophile to afford the desired final 
product. In 2016, the first copper-catalyzed intramolecular oxidative amination was reported by $\mathrm{Xu}$ and $\mathrm{Lu}$ [162]. The novel procedure features the use of a cheap source of copper, which is copper(II) 2-ethylhexanoate, and Dess-Martin periodinane (DMP) as the oxidant. Mechanistic insights reveal the formation of an amidyl radical (Scheme 45) that undergoes a 5-exo-trig cyclization to afford an organocuprate species. Finally, $\beta$-hydride elimination leads to the formation of the vinyl-substituted imidazolidin-2-one with high trans diastereoselectivity.

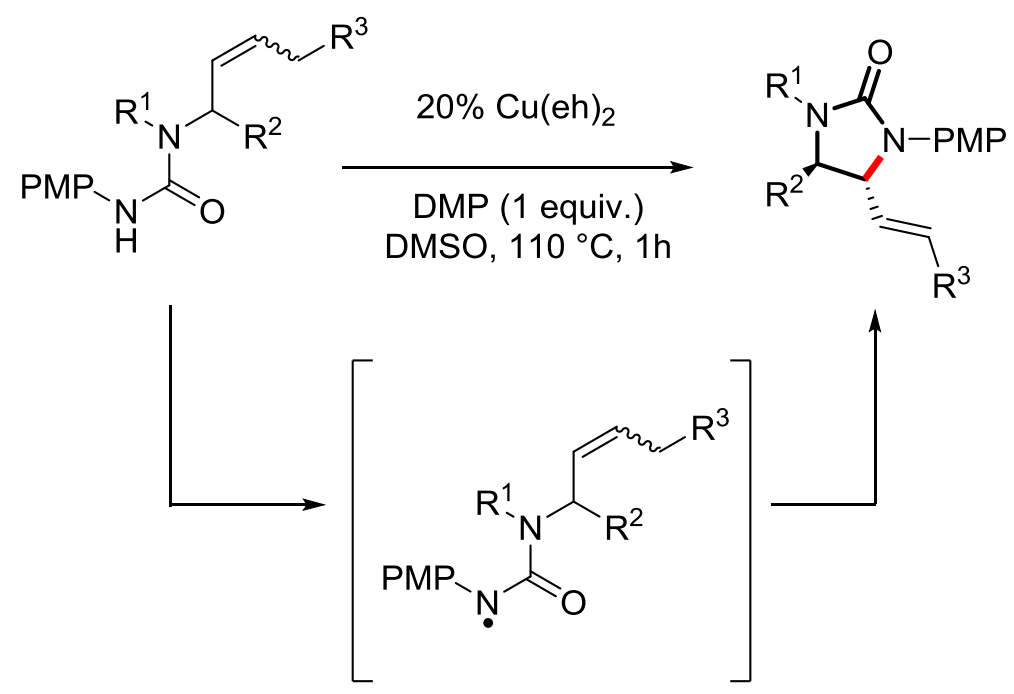

Scheme 45. Copper-catalyzed oxidative amination of $N$-allyl ureas [162].

The effect of gold catalysis in the intramolecular hydroamination of $\mathrm{N}$-allylic ureas to imidazolidin-2-ones has been studied by Widenhoefer et al. [163]. The selected catalytic system involving the use of di-tert-butyl-o-biphenyl phosphine gold(I) chloride and silver hexafluoroantimonate led to the isolation of a wide variety of imidazolidin-2-one derivatives with high diastereoselectivity toward the trans product (Scheme 46).<smiles>[R]C(C=C)N([R1])C(=O)N[Al-]</smiles>

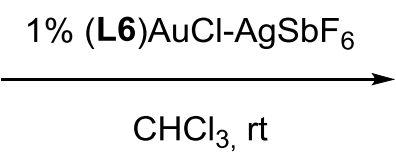<smiles>[R][R]1C([R])N([14CH3])C(=O)N1[Al-]</smiles>

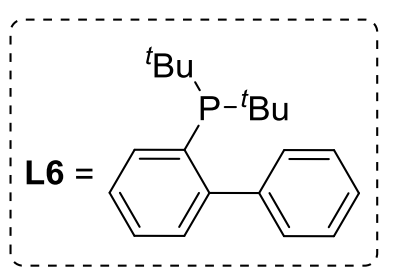

Yields $=86-100 \%$ dr 50:1

Scheme 46. Gold(I)-catalyzed hydroamination of $N$-allylic ureas [163].

Zhang in 2014 reported a gold(I)-catalyzed 5-exo-trig cyclization of $N$-allyl- $N^{\prime}$-phenylurea followed by a gold (III) $\mathrm{C}-\mathrm{H}$ functionalization to afford indoline products via formal [3 + 2] annulation [164]. Their optimized reaction conditions include [L7AuNTf $]\left(\mathbf{L} 7=\left(4-\mathrm{CF}_{3} \mathrm{C}_{6} \mathrm{H}_{4}\right)_{3} \mathrm{P}\right)$ as a gold (I) source, selectfluor as an oxidant to afford the active species of gold (III) in THF, and water as additive to enhance the solubility of the oxidant in the reaction media. The reaction mechanism starts with a cationic gold (I) that promotes a 5-exo-trig cyclization to afford the formation of the imidazolidin-2-one scaffold. Then, selectfluor acts as an oxidant to result in a species of gold (III) which, through 
electrophilic aromatic auration, produces the tricyclic indoline scaffold after reductive elimination (Scheme 47).
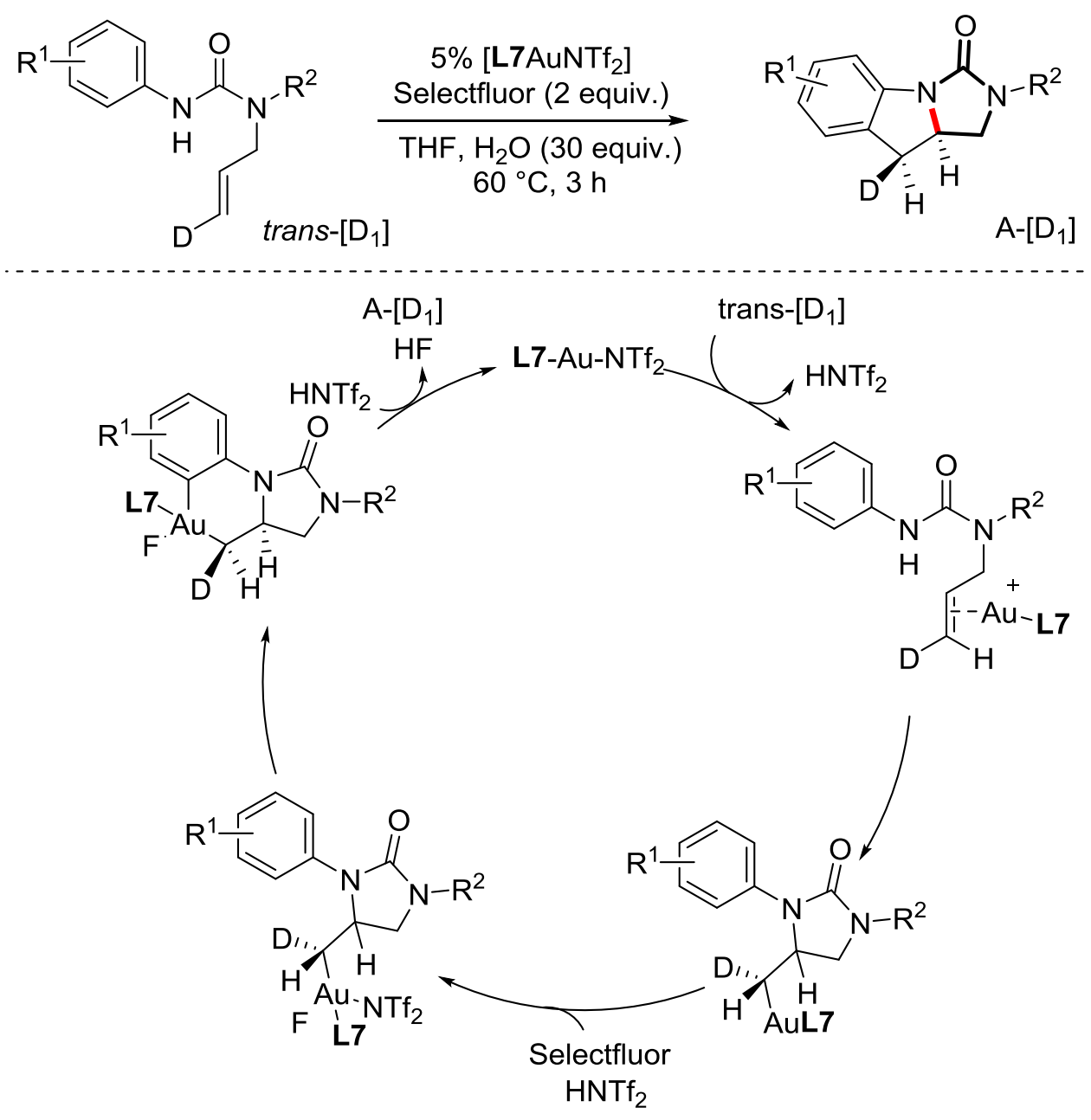

Scheme 47. Gold(I)-catalyzed 5-exo-trig cyclization followed by a gold III C-H functionalization [164].

Very recently, Prestat and Berhal proposed an iron-catalyzed methodology for the construction of an imidazolidin-2-one scaffold [165]. Their approach consists in the anti aminooxygenation of allylbenzoyloxy ureas using iron acetate and phenanthroline as a catalytic system in acetonitrile at 100 degrees (Scheme 48). Several control experiments were performed in order to define the most plausible reaction mechanism, and they found out that both a fused aziridine and a carbocation could represent potential intermediates.
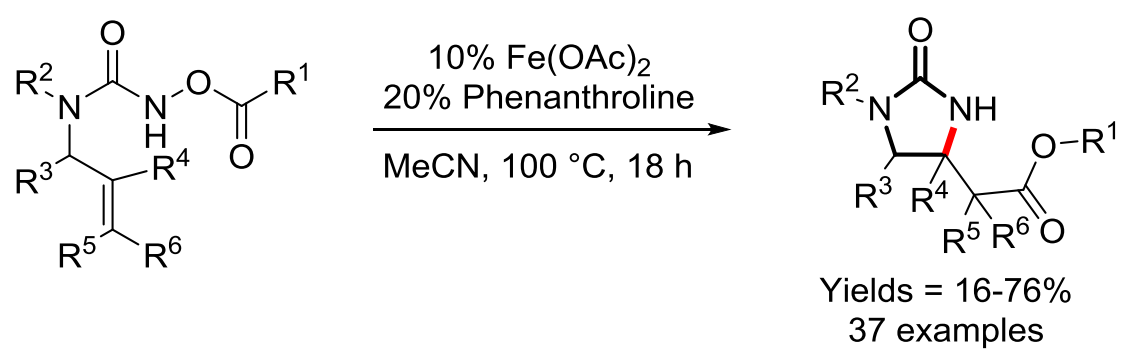

Scheme 48. Iron-catalyzed amino oxygenation of allylbenzoyloxy ureas [165]. 


\section{Catalytic Aziridine Ring Expansion}

Aziridines represent a very useful and versatile substrate to obtain imidazolidin-2-ones. Some selected reactions and methodologies are reported in this chapter, with particular regard to innovative and catalytic procedures.

\subsection{Palladium-Catalyzed Aziridine Ring Expansion Reactions}

To show significant progresses in this field, it is important to refer first to the reactions performed by Alper et al. Vinyl aziridines have been largely utilized as coupling partners in cycloaddition reactions with isocyanates; the vinyl group on the aziridine enhances the reactivity of the aziridine itself. For example, in Pd-catalyzed coupling reactions, the vinyl group enhances the binding of the aziridine substrate, but also in non-metal mediated reactions, the vinyl group is able to favor the reaction, since it is an activating group. In 2000, Alper et al., who had already published the cycloaddition of aziridines and carbodiimides to form imidazolidinimine [166], reported the catalytic preparation of imidazolidin-2-ones by the ring-opening cyclization reaction of 2-vinylaziridines with isocyanates in the presence of palladium acetate and $\mathrm{PPh}_{3}$ (Scheme 49) [167].

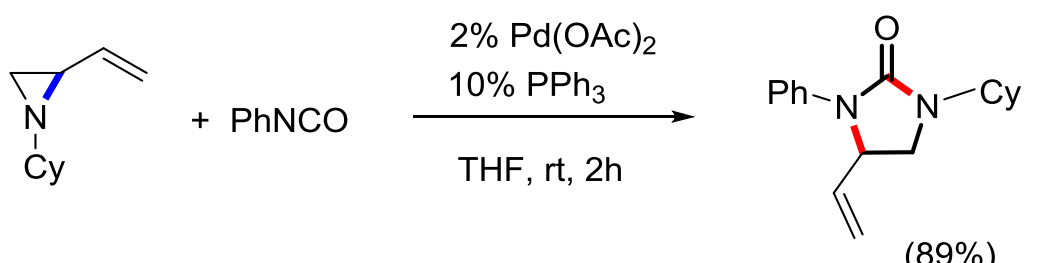

$(89 \%)$

Scheme 49. Pd-catalyzed cyclization of 2-vinylaziridines with isocyanates to imidazolidin-2-ones [167].

The reaction is carried out under very mild conditions, at room temperature and atmospheric pressure, and gives access to a wide array of imidazolidin-2-one derivatives in good yields (34-97\%). The proposed mechanism is reported in Scheme 50. A 16-electron palladium-(0) complex reacts with the substituted alkene, leading to a $\eta^{3}$ intermediate III, thanks to the relatively strong coordinating effect of the nitrogen lone pair of the aziridine cycle. The resulting intermediate III displays a strongly nucleophilic nitrogen, which readily reacts with the electrophilic carbon of the isocyanate (or a different heterocumulene used as the partner reagent), giving rise to intermediate IV in equilibrium with $\mathbf{V}$. Two possible five-membered rings can be generated from complexes IV and $\mathbf{V}$ respectively, with the regeneration of the palladium(0) complex. The more thermodynamically stable product is obtained by isomerization because of the equilibrium between the ring closing and opening steps. In the absence of palladium, the reaction did not occur under these conditions. 


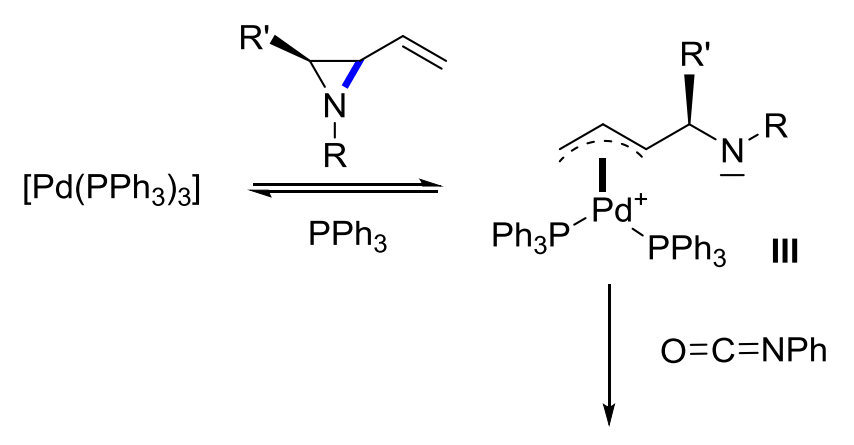

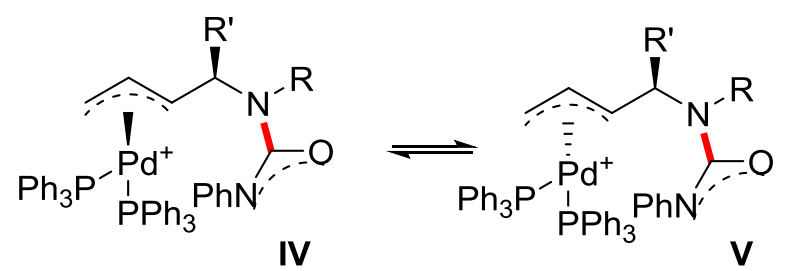

Scheme 50. Proposed mechanism for Pd-catalyzed cyclization of 2-vinylaziridines with isocyanates.

Alper observed that using cis-aziridine resulted in a mixture of products containing an approximately 2:1 ratio of cis and trans stereoisomers. The absence of stereospecificity can be explained by the facile interconversion between intermediates IV and $\mathbf{V}$.

First attempts to control the stereochemistry of this reaction by cooling and using bulkier phosphine ligands, such as DPPB (DPPB $=1$,4-bis(diphenylphosphino)butane), lead to isomeric mixtures. In 2003 Trost et al. reported the first asymmetric cycloaddition of isocyanates to vinylaziridines (Scheme 51) [168].
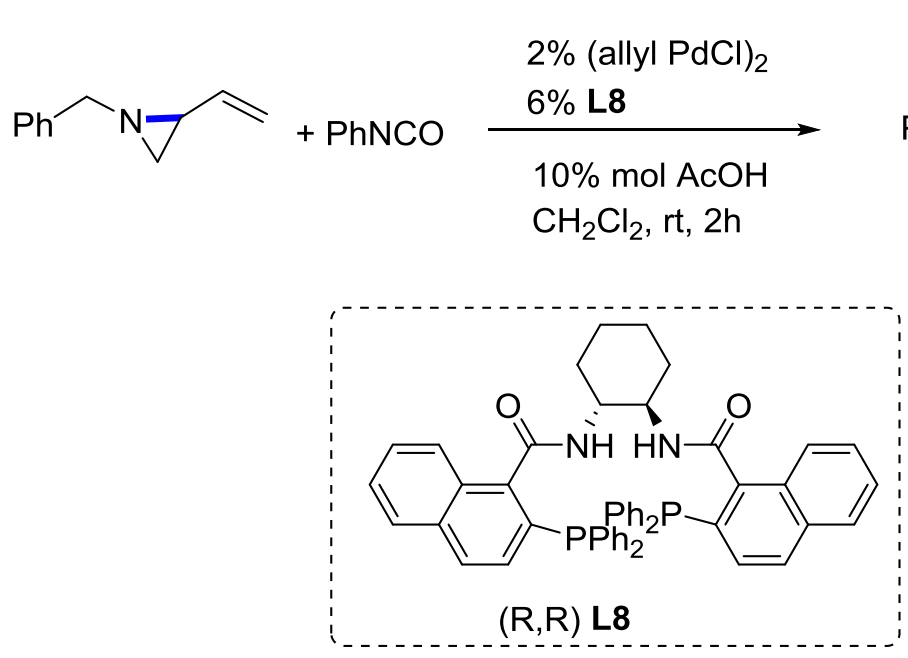<smiles>C=CC1CN(Cc2ccccc2)C(=O)N1c1ccccc1</smiles>

yield $82 \%$ ee $99 \%$

Scheme 51. Asymmetric cycloaddition reaction of isocyanates and vinylaziridines by Trost ligand (L8) [168]. 
In 2004, Alper et al. reported the same asymmetric cycloaddition using BINAP as the ligand and $\mathrm{CeCl}_{3}$ to promote the reaction (Scheme 52) [169].

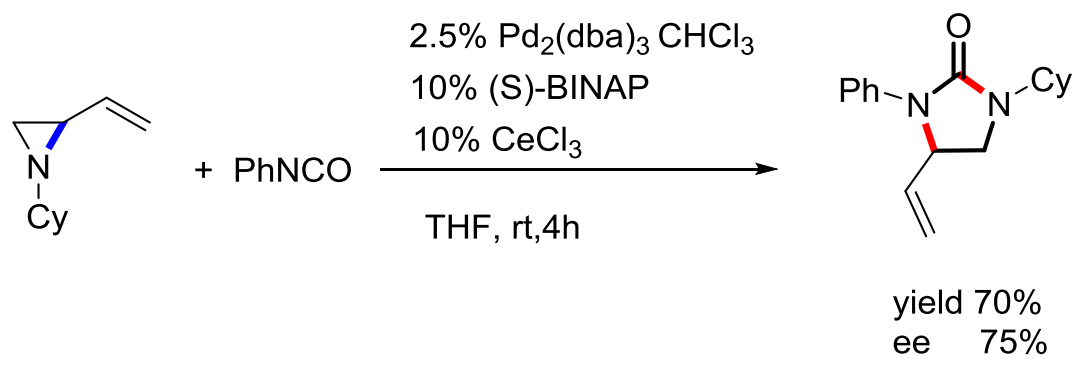

Scheme 52. Asymmetric cycloaddition reaction of isocyanates and vinylaziridines in presence of $\mathrm{CeCl}_{3}[169]$.

The use of $\mathrm{CeCl}_{3}$, acting as Lewis acid, improves the enantioselectivity of the reaction, which is carried out using the readily available BINAP ligand. If an alkynyl aziridine, bearing a 2-aminoalkyl moiety, is caused to react with an isocyanate, two different kinds of biheteroaryl compounds can be obtained by a domino cyclization, as reported by Ohno et al. (Scheme 53) [170].
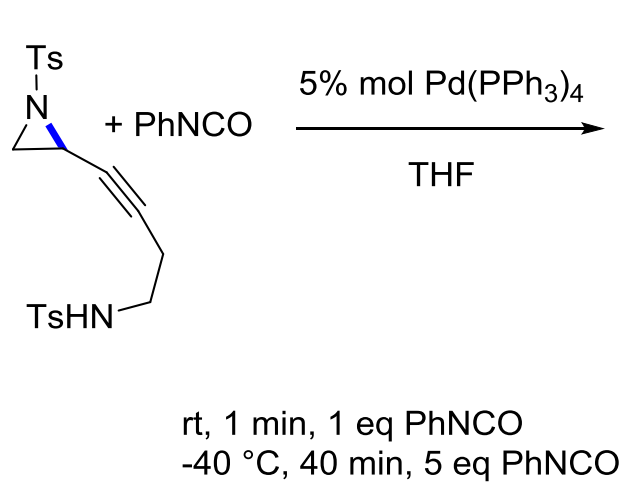

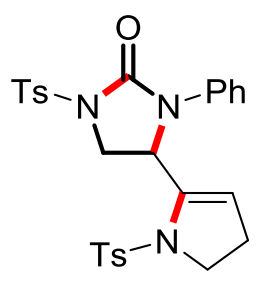

3

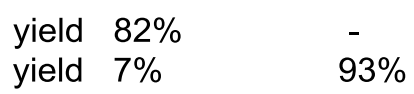

Scheme 53. Domino cyclization of 2-alkynylaziridines bearing a 2-aminoethyl Group via ring expansion with isocyanate [170].

Accurately tuning the conditions (molar ratios, temperatures, and reaction times) allows selectively obtaining the compound containing two five-membered cycles (3) (rt, equimolar ratio of reagents), or the compound containing a seven-membered cycle $(4)\left(-40^{\circ} \mathrm{C}\right.$, excess of isocyanate), resulting from the addition of a second molecule of isocyanate.

\subsection{Nickel-Catalyzed Aziridine Ring Expansion Reactions}

The reaction of isocyanates and aziridines to imidazolidin-2-ones may be catalyzed by nickel salts as well. In 2006, Saito et al. reported the [3 +2$]$ cross-coupling reaction reported below (Scheme 54) [171].

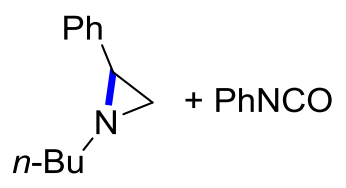<smiles>N#[R]O[Na]</smiles><smiles>CCCCN1CC(c2ccccc2)N(c2ccccc2)C1=O</smiles>

(84\%)

Scheme 54. Ni-catalyzed reaction of aziridines with isocyanates [171]. 
Using a relatively short reaction time (one hour), the main product that was isolated is an iminooxazolidine, which isomerizes to the imidazolidinon-2-one, by the action of a nickel catalyst if the reaction is carried out for longer time. The mechanism reported below (Scheme 55) shows the combined cyclization and isomerization pathways. $\mathrm{NiI}_{2}$ plays a very important role, because iodide anions act as nucleophiles in the first part to break the aziridine cycle, while in the second part, nickel acts as a Lewis acid to promote the isomerization of iminooxazolidine to imidazolidinon-2-one.

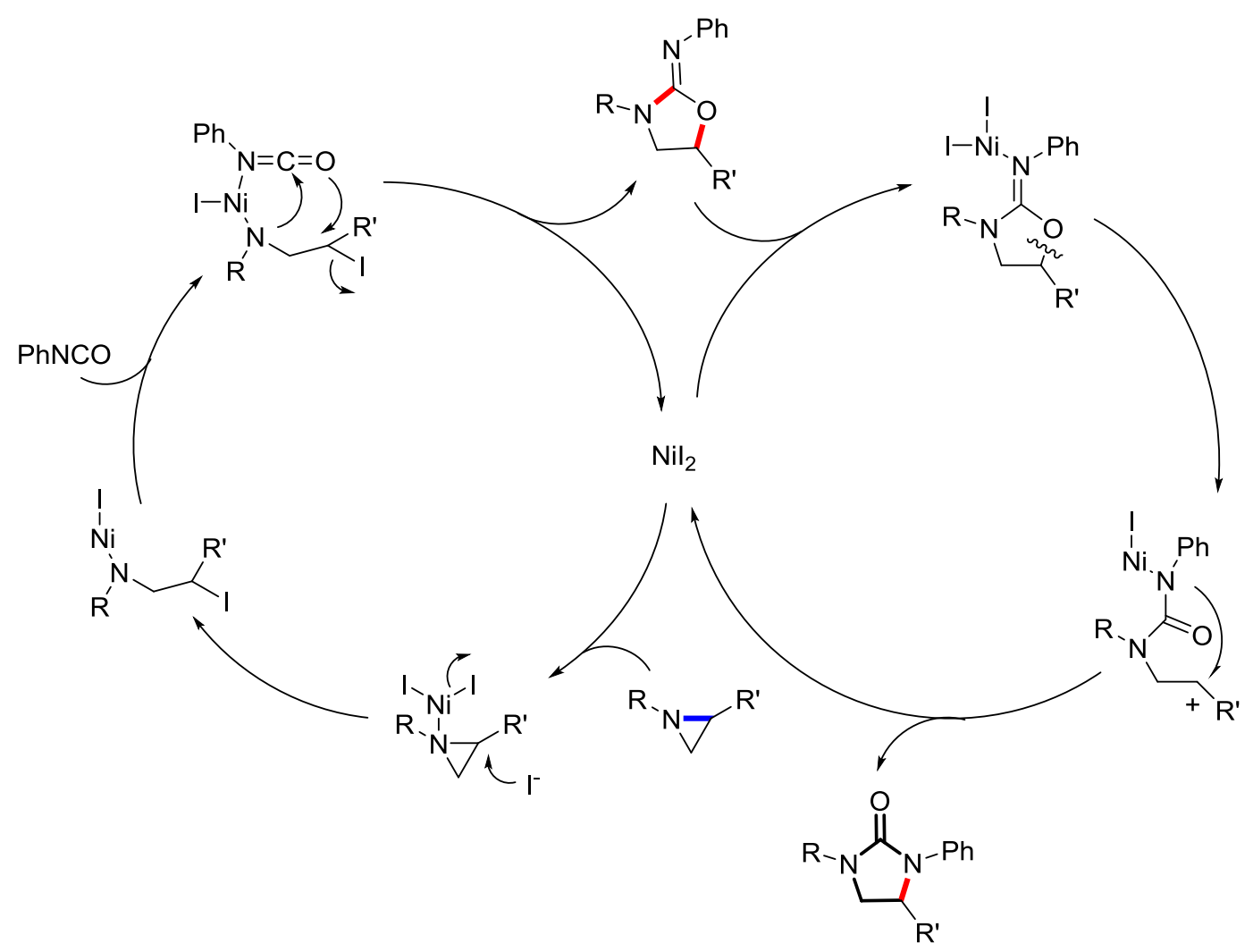

Scheme 55. Proposed mechanism for nickel-catalyzed reaction of aziridines with isocyanates [171].

In 2008, Louie et al. reported on the ring-expansion reaction of vinylaziridines and isocyanates under thermal conditions, using $\mathrm{Ni}$ as the catalyst [172]. If no catalyst is added and thermal conditions $\left(100^{\circ} \mathrm{C}\right)$ are used, no imidazolidinon-2-ones are observed, and compounds such as oxazolidinones or seven-membered heterocycles are found in the final reaction mixtures. When a Ni catalyst is used in combination with NHC ligands, good yields and selectivities can be obtained under relatively mild conditions, and a wide variety of imidazolidinon-2-ones is made accessible (Scheme 56).

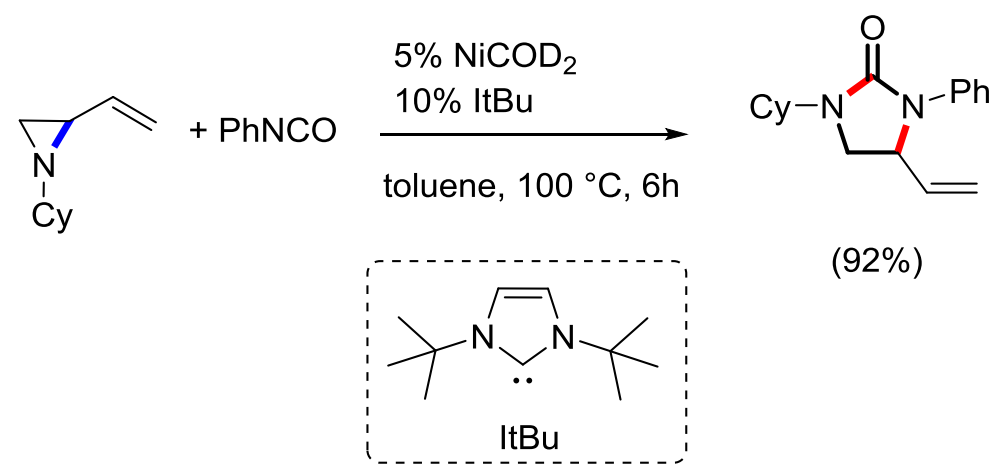

Scheme 56. Ni-catalyzed coupling reaction of vinylaziridines and isocyanates [172]. 


\subsection{Other Catalytic Aziridine Ring-Expansion Reactions}

In 2005, Nadir et al. reported the ring-opening reactions of $N$-arylsulfonylaziridines with isocyanates in the presence of iodide anions to give 2-imidazolidinones (Scheme 57) [173].

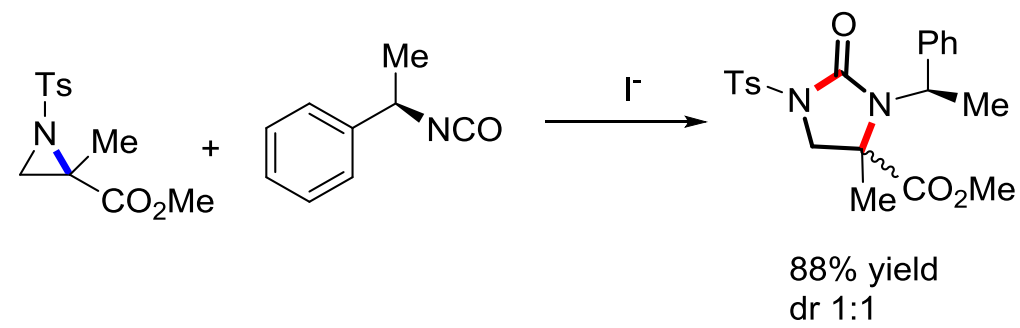

Scheme 57. Iodide-catalyzed reaction of functionalized aziridines with chiral isocyanates [173].

In 2005, Lee et al. reported on the first Lewis acid-catalyzed regiospecific and stereospecific cycloaddition reaction involving chiral aziridine-2-carboxylates with isocyanates (Scheme 58) [174].

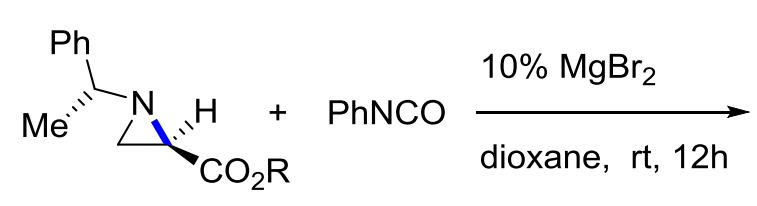<smiles>[R]OC1CN([C@H](C)c2ccccc2)C(=O)N1c1ccccc1</smiles>

Scheme 58. Lewis acid-catalyzed reaction of functionalized aziridines and isocyanates [174].

A wide array of enantiomerically pure imidazolidin-2-one-4-carboxylates can be obtained in a one-step, simple, and highly efficient manner using a Lewis acid-catalyzed ring expansion reaction of the commercially available chiral aziridines with isocyanates. These reactions proceed both regiospecifically and stereospecifically with the retention of the configuration at the C-2 of the chiral aziridines.

\subsection{Non-Catalytic Aziridine Ring-Expansion Reactions}

The ring expansion of aziridines to obtain imidazolidin-2-one derivatives may be also carried out using triphosgene and sodium hydride. This methodology has been recently applied with good results by Lee et al. to obtain precursors of aminoacyl-tRNA synthase inhibitors (Scheme 59) [175].<smiles>[R]C(N)C(=O)NC([R])C(C)OC</smiles>
i) $\mathrm{MgSO}_{4}$ ii) $\mathrm{NaBH}_{3} \mathrm{CN}$<smiles>[R]C(NC(=O)C([R])NCC1CN1[C@H](C)c1ccccc1)C(C)=O</smiles><smiles>[R]C(NC(C)=O)C(=O)C([R])N1C[C@H](CCl)N(C(C)c2ccccc2)C1=O</smiles>

Scheme 59. Synthesis of imidazolidinon-2-ones by triphosgene and sodium hydride [175]. 
This methodology based on the reaction of triphosgene and sodium hydride with aziridines has been used by the same authors to prepare more general biologically active compounds. The reagents can be obtained by the simple addition of benzyl amines to chiral methyl cis-3-aziridin-2-yl-acrylates and the reaction proceeds with high yields and stereoselectivities (Scheme 60) [176].

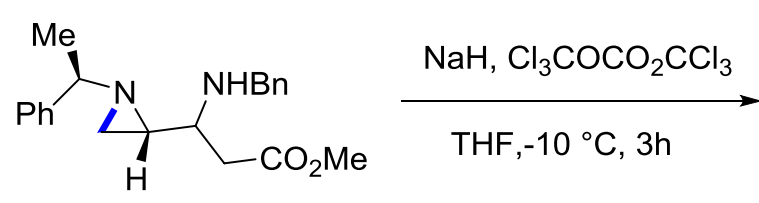<smiles>COCCC1[C@H](Cc2ccccc2)N(C(C)c2ccccc2)C(=O)N1C</smiles>

Scheme 60. Formation of imidazolidinon-2-ones by reaction of azyridine derivatives with triphosgene and $\mathrm{NaH}[176]$.

Recently, Besbes et al. reported aziridine ring expansion to give imidazolidin-2-ones [177]. In particular, using $\mathrm{N}$-alkylaziridine-2-carboxylates with $\mathrm{N}$-alkyl isocyanates under catalyst free conditions, trans imidazolidin-2-ones can be obtained with good yields and high regioselectivity and stereoselectivity (Scheme 61) [177].<smiles>CCOC(=O)C1C(c2ccccc2)N1C(=O)NON=O</smiles><smiles>CCOC(=O)C1C(c2ccccc2)N(C(C)C)C(=O)N1C(C)C</smiles>

$(95 \%)$

Scheme 61. Metal-free reaction of functionalized aziridines and isocyanates [177].

\section{Miscellaneous}

Several other methods that could not be grouped in the previous sections are herein described. One interesting approach for the construction of imidazolidin-2-one scaffold features the involvement of the aza-Michael reaction. Wolfe reported a ruthenium-catalyzed cross-metathesis followed by the aza-Michael reaction of $N$-allyl ureas and $\alpha, \beta$ unsaturated compounds [178]. The most efficient catalyst is the Hoveyda-Grubbs II in presence of CuI, and this system gave access to different substituted cyclic ureas with a trans diastereoselectivity (Scheme 62).

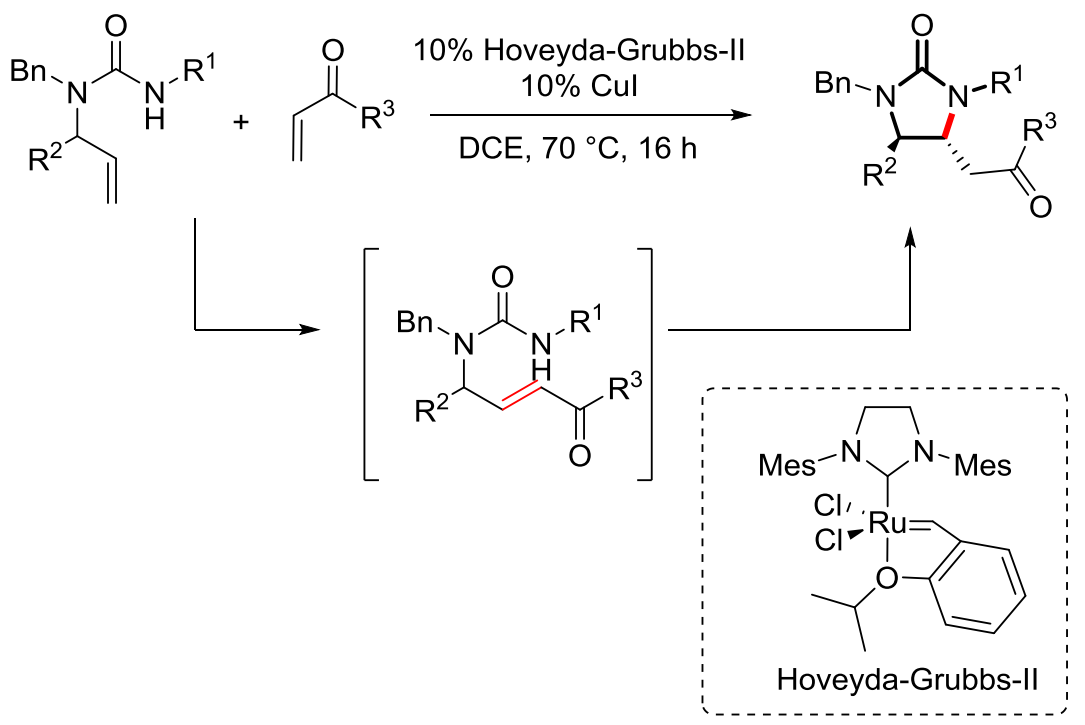

Scheme 62. Cross-metathesis/aza-Michael strategy to access imidazolidin-2-ones [178]. 
The aza-Michael strategy was also applied in the synthesis of enantioenriched $\beta, \gamma$-diamino acid derived imidazolidin-2-ones by Terada [179]. $\gamma$-Amino- $\alpha, \beta$-unsaturated esters were caused to react with tosyl isocyanates in a formal [3 + 2] cycloaddition using $10 \%$ of DIPEA as the catalyst. The reaction evolves with a perfect anti diastereoselectivity and affords the enantioenriched imidazolidin-2-ones with up to $93 \%$ of enantiomeric excess.

A similar approach was applied to the desymmetrization of cyclohexadienones with isocyanates in presence of a catalytic amount of DBU (1,8-Diazabicyclo(5.4.0)undec-7-ene) [180]. The authors reported the synthesis of a broad range of bicyclic imidazolidin-2-ones with high diastereomeric ratios (Scheme 63). The applicability of this protocol was further displayed with a multi-gram scale reaction.

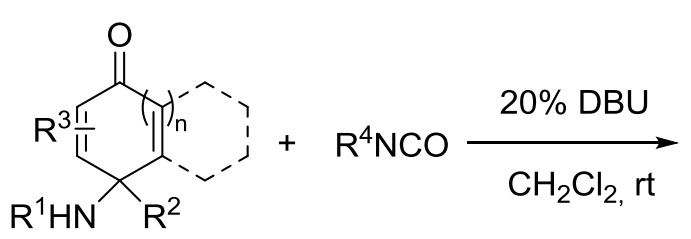<smiles>[R]NC(=O)N([R])C1([R])CCCCC1CCC</smiles>

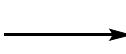

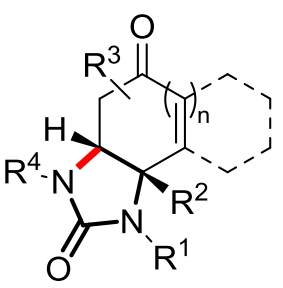

44 examples dr 20:1

Scheme 63. DBU-catalyzed sequential nucleophilic/aza-Michael addition [180]. DBU: 1,8-Diazabicyclo(5.4.0)undec-7-ene.

The same base was also employed as a catalyst in the cyclization of $\beta$-amino carbamates to promote the formation of the imidazolidin-2-one scaffold [181].

Nowadays, electrochemistry is considered a fundamental tool in order to pursuit a greener and more sustainable chemistry [182]. In the last few years, the imidazolidin-2-one scaffold has been constructed also, taking advantage from an electrochemical methodology. In 2017, Xu et al. published an electrochemical intramolecular oxidative amination [183]. They formed a nitrogen-centered radical via anodic activation that can react with a double bond, generating a carbon-centered radical. This approach proceeds with the oxidation of the radical-centered carbon with the regeneration of the double bond after proton abstraction (Scheme 64).<smiles>[R]/C(=C(\[R])C([R7])([R])[2H])C([R7])N([R6])C(=O)N[Ga]</smiles>

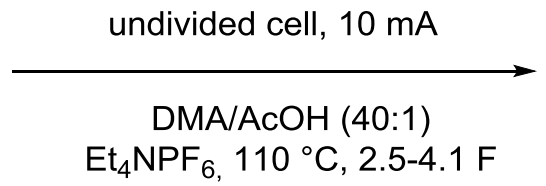

$$
\downarrow \begin{aligned}
& -\mathrm{e}^{-} \\
& -\mathrm{H}^{+}
\end{aligned}
$$<smiles>[R]/C(=C(\[R])C([R7])([R])[Y])C([R7])N([R7])C(=O)N[Al]</smiles><smiles>[R]C1C([R])N([Ga])C(=O)N1[R]</smiles>

Scheme 64. Electrochemical oxidative amination of alkenes [183]. 
In 2018, Ahmed proposed a similar methodology involving the electrochemical formation of the nitrogen radical followed by cyclization and then radical recombination using TEMPO (Scheme 65) [184].<smiles>[R]N(CC=C)C(=O)N[AlH2]</smiles>

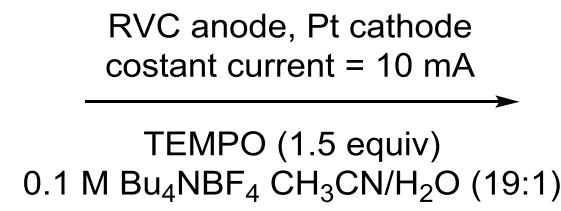

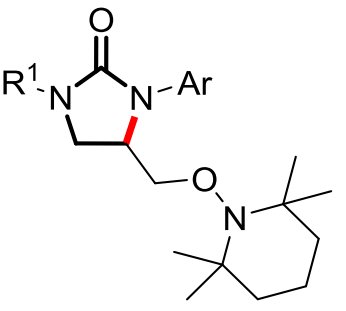

Scheme 65. Electrochemical intramolecular amination of $N$-allylic ureas [184].

Palladium is known to promote olefin isomerization followed by oxidative olefin amination in order to generate anti-imidazolidin-2-ones. In 2013, White reported this strategy [185] in the presence of palladium acetate, using a Lewis acid as an isomerization promoter and an external oxidant to restore the double-bond functionality (Scheme 66).<smiles>[R]C(CC=C)NC(=O)NNS(C)(=O)=O</smiles>

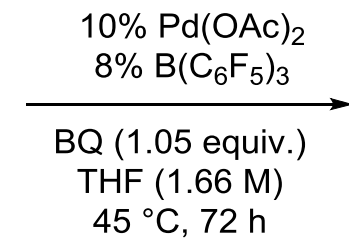

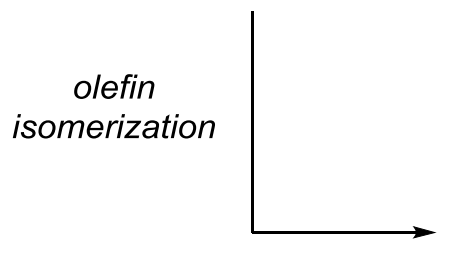

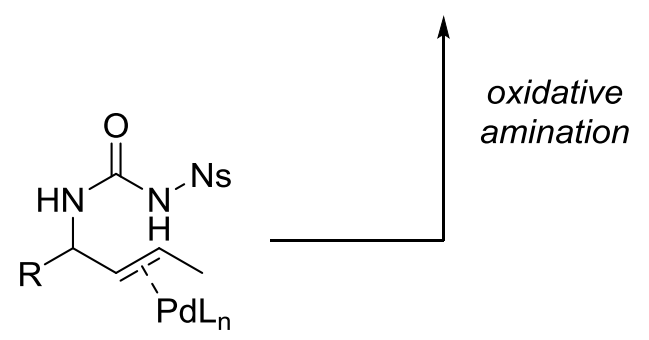<smiles>[R]C1NC(=O)N([S@@](=O)[O-])[C@@H]1C=C</smiles>

oxidative amination

Scheme 66. Pd-catalyzed olefin isomerization followed by oxidative amination [185].

Aza-Heck reaction, promoted by a palladium species, was applied to $N$-allyilic, $N^{\prime}$-phenoxy ureas to obtain imidazolidin-2-ones bearing an additional double bond (Scheme 67) [186]. This strategy features the use of a cheap and accessible source of palladium(II) and it gives access to free $\mathrm{N}-\mathrm{H}$ imidazolidinones with a broad substrate scope and functional group tolerance.<smiles>[R7]CC([R])=C([R])C([R])N([R])C(=O)NOc1ccccc1</smiles>

$2.5 \%[(\text { cinnamyl }) \mathrm{PdCl}]_{2}$ $5 \% \mathrm{P}\left(\mathrm{OCH}_{2} \mathrm{CF}_{3}\right)_{3}$

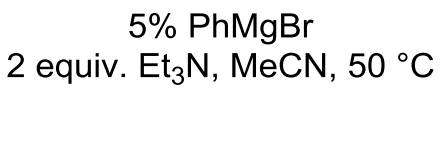

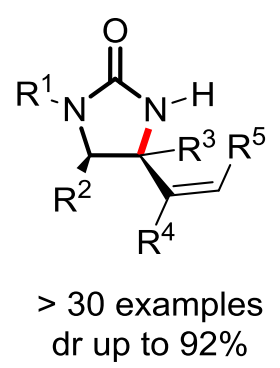

Scheme 67. Aza-Heck reaction for the synthesis of free N-H imidazolidinones [186].

Different strategies have been developed for the synthesis of benzimidazolidinones. In 2015, $\mathrm{Fu}$ et al. proposed a metal-free oxidative $\mathrm{C}-\mathrm{H}$ amidation of $N, N^{\prime}$-diarylureas (Scheme 68) [187]. $\mathrm{PhI}(\mathrm{OAc})_{2}$ acts as inexpensive oxidant to form an $\mathrm{N}-\mathrm{I}$ bond, which after heterolysis affords a nitrogen cation that is responsible for an intramolecular electrophilic addition on the aromatic ring. 


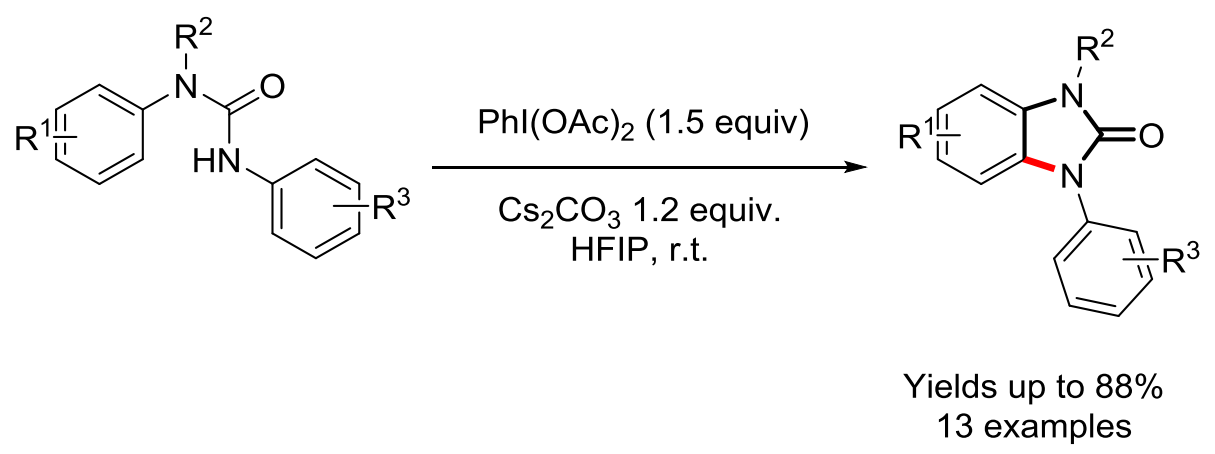

Scheme 68. Synthesis of benzimidazolidinones using $\mathrm{PhI}(\mathrm{OAc})_{2}$ as oxidant [187].

Rhodium catalysis was investigated for the synthesis of benzimidazolidinones via a double decarbonylation-cycloaddition strategy [188]. The reported methodology involves a formal [5 - 2 +2] transformation between isatins and isocyanates as coupling partners (Scheme 69). Intensive mechanistic studies confirmed the double-decarbonylative pathway and led to a proposed four-member rhodium-containing cycle as intermediate, whose formation was allowed by the presence of 3-methyl-2-pyridinyl, which directs the metal insertion. A wide variety of functional groups was tolerated, affording good to excellent yields of benzimidazolidin-2-ones.
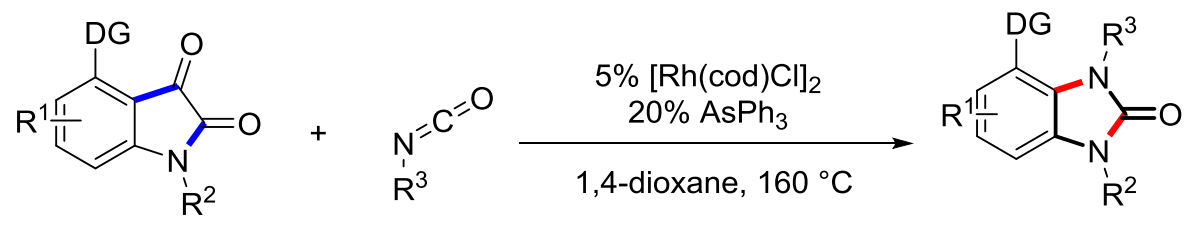

DG: 3-methyl-2-pyridinyl 


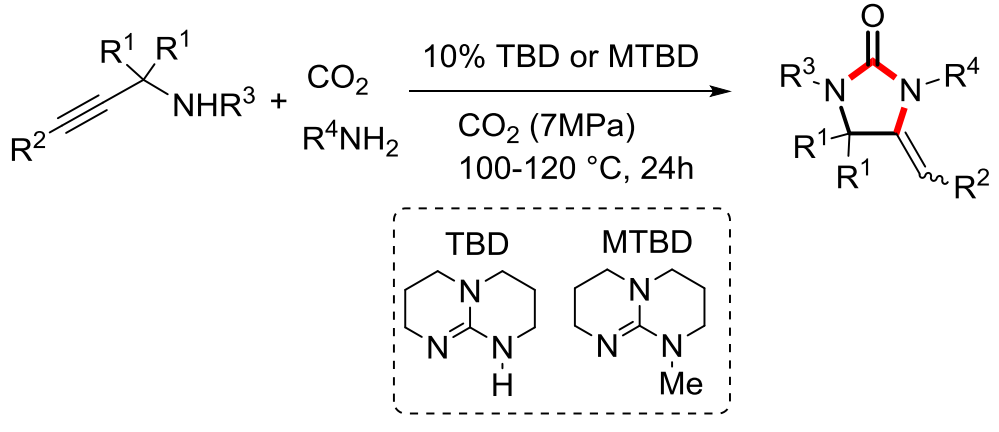

Scheme 70. Bicyclic guanidine-catalyzed synthesis of 2-imidazolidinones from propargylamines, primary amine, and $\mathrm{CO}_{2}[189]$.

\section{Conclusions}

The omnipresence of imidazolidin-2-one structure in natural products, bioactive molecules, and organic intermediates justifies the continuous interest in developing new and more sustainable protocols for their synthesis. In this review, the most exploited catalytic strategies for the construction of 2-imidazolidinone core have been summarized, and the most important aspects of each protocol have been highlighted. To the best of our knowledge, a comprehensive collection on the existing methods for the synthesis of 2-imidazolidinones and 2-benzimidazolidinones is missing in the literature.

Future developments in the field will probably involve the use of less toxic and easily available reagents or less expensive metal catalysts. The discovery of more efficient organocatalysts for their production is also expected. Variously functionalized 2-imidazolidinones and 2-benzimidazolidinones have been successfully synthesized; however, a higher level of molecular complexity can be obtained in the future, taking advantage of sequential reactions.

Funding: This research received no external funding.

Conflicts of Interest: The authors declare no conflict of interest.

\section{Abbreviations}

$\begin{array}{ll}\text { BINAP } & \text { 2,2'-bis(diphenylphosphino)-1,1'-binaphthyl } \\ \text { BINOL } & {\left[1,1^{\prime} \text {-binaphthalene]-2,2'-diol }\right.} \\ \text { BQ } & \text { 1,4-Benzoquinone } \\ \text { DCE } & \text { 1,2-Dichloroethane } \\ \text { DCM } & \text { Dichloromethane } \\ \text { DIPEA } & \text { N,N-Diisopropylethylamine } \\ \text { DMF } & N, N \text {-Dimethylformamide } \\ \text { MeCN or ACN } & \text { Acetonitrile } \\ \text { MS } & \text { Molecular sieves } \\ \text { NHC } & N \text {-heterocyclic carbenes } \\ \text { NMP } & N \text {-Methyl-2-pyrrolidone } \\ \text { PhI(OAc) } 2 & \text { (Diacetoxyiodo)benzene } \\ \text { RNA } & \text { Ribonucleic acid } \\ \text { rt or RT } & \text { Room temperature } \\ \text { TBAF } & \text { Tetra- } n \text {-butylammonium fluoride } \\ \text { TEMPO } & \text { 2,2,6,6-Tetramethyl-1-piperidinyloxy, free radical } \\ \text { Tf } & \text { Triflate } \\ \text { THF } & \text { Tetrahydrofuran } \\ \text { TBD } & \text { 1,5,7-Triazabicyclo[4.4.0]dec-5-ene } \\ \text { MTBD } & \text { 7-Methyl-1,5,7-triazabicyclo[4.4.0]dec-5-ene } \\ \text { VOC } & \text { Volatile Organic Compound }\end{array}$




\section{References}

1. Lee, K.-C.; Venkateswararao, E.; Sharma, V.K.; Jung, S.-H. Investigation of amino acid conjugates of (S)-1-[1-(4-aminobenzoyl)-2,3-dihydro-1H-indol-6-sulfonyl]-4-phenyl-imidazolidin-2-one (DW2282) as water soluble anticancer prodrugs. Eur. J. Med. Chem. 2014, 80, 439-446. [CrossRef] [PubMed]

2. Pettit, G.R.; McNulty, J.; Herald, D.L.; Doubek, D.L.; Chapuis, J.-C.; Schmidt, J.M.; Tackett, L.P.; Boyd, M.R. Antineoplastic Agents. 362. Isolation and X-ray Crystal Structure of Dibromophakellstatin from the Indian Ocean Sponge Phakellia mauritiana. J. Nat. Prod. 1997, 60, 180-183. [CrossRef]

3. Chang, C.-S.; Lin, Y.-T.; Shih, S.-R.; Lee, C.-C.; Lee, Y.-C.; Tai, C.-L.; Tseng, S.-N.; Chern, J.-H. Design, Synthesis, and Antipicornavirus Activity of 1-[5-(4-Arylphenoxy)alkyl]-3-pyridin-4-ylimidazolidin-2-one Derivatives. J. Med. Chem. 2005, 48, 3522-3535. [CrossRef] [PubMed]

4. Reichard, G.A.; Stengone, C.; Paliwal, S.; Mergelsberg, I.; Majmundar, S.; Wang, C.; Tiberi, R.; McPhail, A.T.; Piwinski, J.J.; Shih, N.-Y. Asymmetric Synthesis of 4,4-Disubstituted-2-Imidazoli-dinones: Potent NK 1 Antagonists. Org. Lett. 2003, 5, 4249-4251. [CrossRef]

5. Kaneko, H.; Ikawa, T.; Yamamoto, Y.; Arulmozhiraja, S.; Tokiwa, H.; Akai, S. 3-(Triflyloxy)benzynes Enable the Regiocontrolled Cycloaddition of Cyclic Ureas to Synthesize 1,4-Benzodiazepine Derivatives. Synlett 2018, 29, 943-948.

6. Rajesh, M.; Puri, S.; Kant, R.; Sridhar Reddy, M. Ag-Catalyzed Intramolecular Sequential Vicinal Diamination of Alkynes with Isocyanates: Synthesis of Fused Indole-Cyclic Urea Derivatives. J. Org. Chem. 2017, 82, 5169-5177. [CrossRef] [PubMed]

7. Koswatta, P.; Sivappa, R.; Dias, H.; Lovely, C. Total Synthesis of the Leucetta-Derived Alkaloid Calcaridine A. Synthesis 2009, 2009, 2970-2982.

8. Vasanthakumar, G.R.; Bhor, V.M.; Surolia, A. Hydrolysis of Cyclic Ureas under Microwave Irradiation: Synthesis and Characterization of 7,8-Diaminopelargonic Acid. Synth. Commun. 2007, 37, $2633-2639$. [CrossRef]

9. Barrios Sosa, A.C.; Yakushijin, K.; Horne, D.A. Synthesis of Slagenins A, B, and C. Org. Lett. 2000, 2, 3443-3444. [CrossRef] [PubMed]

10. Hodges, T.R.; Abbott, J.R.; Little, A.J.; Sarkar, D.; Salovich, J.M.; Howes, J.E.; Akan, D.T.; Sai, J.; Arnold, A.L.; Browning, C.; et al. Discovery and Structure-Based Optimization of Benzimidazole-Derived Activators of SOS1-Mediated Nucleotide Exchange on RAS. J. Med. Chem. 2018, 61, 8875-8894. [CrossRef]

11. Lu, C.; Hu, L.; Yang, G.; Chen, Z. 2-Imidazolidinones as Chiral Auxiliaries in Asymmetric Synthesis. Curr. Org. Chem. 2012, 16, 2802-2817. [CrossRef]

12. Guillena, G.; Nájera, C. (4R,5S)-1,5-Dimethyl-4-phenylimidazolidin-2-one as a chiral auxiliary for the diastereoselective alkylation of a new iminic glycine derivative: practical asymmetric synthesis of $\alpha$-amino acids. Tetrahedron: Asymmetry 1998, 9, 1125-1129. [CrossRef]

13. Matsunaga, H.; Ishizuka, T.; Kunieda, T. Synthetic utility of five-membered heterocycles-chiral functionalization and applications. Tetrahedron 2005, 61, 8073-8094. [CrossRef]

14. Konnert, L.; Lamaty, F.; Martinez, J.; Colacino, E. Recent Advances in the Synthesis of Hydantoins: The State of the Art of a Valuable Scaffold. Chem. Rev. 2017, 117, 13757-13809. [CrossRef] [PubMed]

15. Antonova, M.M.; Baranov, V.V.; Kravchenko, A.N. Methods for the synthesis of 1-substituted 1H-imidazol-2(3H)-ones. Chem. Heterocycl. Compd. 2015, 51, 395-420. [CrossRef]

16. Kou, Q.; Wang, T.; Zou, F.; Zhang, S.; Chen, Q.; Yang, Y. Design, synthesis and biological evaluation of C(4) substituted monobactams as antibacterial agents against multidrug-resistant Gram-negative bacteria. Eur. J. Med. Chem. 2018, 151, 98-109. [CrossRef] [PubMed]

17. Lockhart, Z.; Knipe, P.C. Conformationally Programmable Chiral Foldamers with Compact and Extended Domains Controlled by Monomer Structure. Angew. Chem. Int. Ed. 2018, 57, 8478-8482. [CrossRef]

18. Remarchuk, T.; Corey, E.J. Stereodivergent synthesis of novel chiral $C_{2}$-symmetric bis-trifluoromethyl-2-oxazolidinones. Tetrahedron Lett. 2018, 59, 2256-2259. [CrossRef]

19. Ramadoss, V.; Alonso-Castro, A.J.; Campos-Xolalpa, N.; Solorio-Alvarado, C.R. Protecting-Group-Free Total Synthesis and Biological Evaluation of 3-Methylkealiiquinone and Structural Analogues. J. Org. Chem. 2018, 83, 10627-10635. [CrossRef] 
20. Ramadoss, V.; Alonso-Castro, A.J.; Campos-Xolalpa, N.; Ortiz-Alvarado, R.; Yahuaca-Juárez, B.; Solorio-Alvarado, C. Total synthesis of kealiiquinone: the regiocontrolled strategy for accessing its 1-methyl-4-arylbenzimidazolone core. RSC Adv. 2018, 8, 30761-30776. [CrossRef]

21. Monaim, S.A.H.A.; Acosta, G.A.; Royo, M.; El-Faham, A.; de la Torre, B.G.; Albericio, F. Solid-phase synthesis of homodetic cyclic peptides from Fmoc-MeDbz-resin. Tetrahedron Lett. 2018, 59, 1779-1782. [CrossRef]

22. Spengler, J.; Blanco-Canosa, J.B.; Forni, L.; Albericio, F. One-Pot Peptide Ligation-Oxidative Cyclization Protocol for the Preparation of Short-/Medium-Size Disulfide Cyclopeptides. Org. Lett. 2018, 20, 4306-4309. [CrossRef] [PubMed]

23. Kikuchi, M.; Kurotani, R.; Konno, H. Synthesis of a secretoglobin 3A2 type C (98-139) fragment by Dawson's native chemical ligation. Tetrahedron Lett. 2017, 58, 4145-4148. [CrossRef]

24. Teno, N.; Iguchi, Y.; Yamashita, Y.; Mori, N.; Une, M.; Nishimaki-Mogani, T.; Gohda, K. Discovery and optimization of benzimidazole derivatives as a novel chemotype of farnesoid $\mathrm{X}$ receptor (FXR) antagonists. Biorg. Med. Chem. 2017, 25, 1787-1794. [CrossRef]

25. Jbara, M.; Maity, S.K.; Seenaiah, M.; Brik, A. Palladium Mediated Rapid Deprotection of N-Terminal Cysteine under Native Chemical Ligation Conditions for the Efficient Preparation of Synthetically Challenging Proteins. J. Am. Chem. Soc. 2016, 138, 5069-5075. [CrossRef]

26. Lin, C.-Y.; Sun, Z.; Xu, Y.-J.; Lu, C.-D. Synthesis of Aryl anti-Vicinal Diamines via Aza-Brook Rearrangement-Initiated Nucleophilic Addition of $\alpha$-Silylamines to Imines. J. Org. Chem. 2015, 80, 3714-3722. [CrossRef] [PubMed]

27. Stanchev, S.; Zawada, Z.; Monincová, L.; Bednárová, L.; Slaninová, J.; Fučík, V.; Čeřovský, V. Synthesis of lucifensin by native chemical ligation and characteristics of its isomer having different disulfide bridge pattern. J. Pept. Sci. 2014, 20, 725-735. [CrossRef]

28. Chavan, S.P.; Chavan, P.N.; Lasonkar, P.B.; Khairnar, L.B.; Kadam, A.L. A Facile and Convenient Synthesis of ( \pm )-Biotin via MgCl2/Et3N-Mediated C-C Coupling and Mitsunobu Reaction. Synlett 2014, 25, $2879-2882$. [CrossRef]

29. Pajkert, R.; Böttcher, T.; Ponomarenko, M.; Bremer, M.; Röschenthaler, G.-V. Synthesis and characterization of novel carbene complexes of phosphorus(V) fluorides with potential liquid-crystalline properties. Tetrahedron 2013, 69, 8943-8951. [CrossRef]

30. Lee, J.-H.; Thanigaimalai, P.; Lee, K.-C.; Bang, S.-C.; Kim, M.-S.; Sharma, V.K.; Yun, C.-Y.; Roh, E.; Kim, Y.; Jung, S.-H. Novel Benzo[d]imidazole-2(3H)-thiones as Potent Inhibitors of the $\alpha$-Melanocyte Stimulating Hormone Induced Melanogenesis in Melanoma B16 Cells. Chem. Pharm. Bull. 2010, 918-921. [CrossRef]

31. Wang, Y.; Wang, Q.; Zhu, J. Organocatalytic Nucleophilic Addition of Hydrazones to Imines: Synthesis of Enantioenriched Vicinal Diamines. Angew. Chem. Int. Ed. 2017, 56, 5612-5615. [CrossRef] [PubMed]

32. Qiao, S.; Wilcox, C.B.; Unruh, D.K.; Jiang, B.; Li, G. Asymmetric [3 + 2] Cycloaddition of Chiral N-Phosphonyl Imines with Methyl Isocyanoacetate for Accessing 2-Imidazolines with Switchable Stereoselectivity. J. Org. Chem. 2017, 82, 2992-2999. [CrossRef] [PubMed]

33. Tian, M.; Yan, M.; Baran, P.S. 11-Step Total Synthesis of Araiosamines. J. Am. Chem. Soc. 2016, 138, 14234-14237. [CrossRef] [PubMed]

34. Ryu, K.E.; Kim, B.R.; Sung, G.H.; Yoon, H.J.; Yoon, Y.-J. Facile Synthesis of Benzo[d]azol-2(3H)-ones Using 2-Phenoxycarbonyl-4,5-dichloropyridazin-3(2H)-one as Green CO Source. Synlett 2015, 26, 1985-1990. [CrossRef]

35. Tolpygin, I.E.; Popova, O.S.; Revinskii, Y.V.; Dubonosov, A.D.; Bren', V.A.; Minkin, V.I. Carbamides as Chemosensors for Cations $\mathrm{Eu}^{3+}$. Russ. J. Org. Chem. 2013, 49, 1238-1240. [CrossRef]

36. Dekhane, D.V.; Pawar, S.S.; Gupta, S.V.; Shingare, M.S.; Thore, S.N. Synthesis of Benzimidazolones, Benzooxazolones, 2-amino-benzothiazoles from Ethyl Cyanoformate and o-phenylene Diamines, o-aminophenols, oaminothiophenols Promoted by Lithium Bromide. Lett. Org. Chem. 2011, 8, $406-411$. [CrossRef]

37. Adardour, M.; Zaballos-García, E.; Loughzail, M.; Dahaoui, S.; Baouid, A. Synthesis, characterization and X-ray structure of heterocyclic systems prepared via 1,3-dipolar cycloaddition of nitrile oxides with benzimidazolone. J. Mol. Struct. 2018, 1165, 153-161. [CrossRef]

38. Wei, S.; Li, L.; Shu, Y.; Zhao, Y.; Ji, Z. Synthesis, antifungal and antitumor activity of two new types of imidazolin-2-ones. Bioorg. Med. Chem. 2017, 25, 6501-6510. [CrossRef] 
39. Yang, F.; Wu, C.; Li, Z.; Tian, G.; Wu, J.; Zhu, F.; Zhang, J.; He, Y.; Shen, J. A Facile Route of Synthesis for Making Flibanserin. Org. Process Res. Dev. 2016, 20, 1576-1580. [CrossRef]

40. Mondieig, D.; Negrier, P.; Leger, J.M.; Lakhrissi, L.; El Assyry, A.; Lakhrissi, B.; Essassi, E.M.; Benali, B.; Boucetta, A. Synthesis and Structural Study of N-Isopropenylbenzimidazolone. Russ. J. Phys. Chem. A 2015, 89, 807-811. [CrossRef]

41. Rekunge, D.S.; Khatri, C.K.; Chaturbhuj, G.U. Sulfated polyborate-catalyzed efficient and expeditious synthesis of (un) symmetrical ureas and benzimidazolones. Tetrahedron Lett. 2017, 58, 4304-4307. [CrossRef]

42. Movsumzade, M.M.; Shatirova, M.I.; Dzhafarova, U.S.; Niyazova, N.K. Investigation of Chemical Properties and Antimicrobial Activity of Acetylene Glycidyl Ethers. Russ. J. Org. Chem. 2018, 88, 389-392. [CrossRef]

43. Devine, W.G.; Diaz-Gonzalez, R.; Ceballos-Perez, G.; Rojas, D.; Satoh, T.; Tear, W.; Ranade, R.M.; Barros-Álvarez, X.; Hol, W.G.J.; Buckner, F.S.; et al. From Cells to Mice to Target: Characterization of NEU-1053 (SB-443342) and Its Analogues for Treatment of Human African Trypanosomiasis. ACS Infect. Dis. 2017, 3, 225-236. [CrossRef] [PubMed]

44. Zhu, C.; Mu, A.U.; Lin, Y.-H.; Guo, Z.-H.; Yuan, T.; Wheeler, S.E.; Fang, L. Molecular Coplanarity and Self-Assembly Promoted by Intramolecular Hydrogen Bonds. Org. Lett. 2016, 18, 6332-6335. [CrossRef] [PubMed]

45. Asteian, A.; Blayo, A.-L.; He, Y.; Koenig, M.; Shin, Y.; Kuruvilla, D.S.; Corzo, C.A.; Cameron, M.D.; Lin, L.; Ruiz, C.; et al. Design, Synthesis and Biological Evaluation of Indole Biphenylcarboxylic acids as PPAR $\gamma$ Antagonists. ACS Med. Chem. Lett. 2015, 6, 998-1003. [CrossRef] [PubMed]

46. Abbas, M.A.; Hameed, S.; Farman, M.; Kressler, J.; Mahmood, N. Conjugates of degraded and oxidized hydroxyethyl starch and sulfonylureas: synthesis, characterization, and in vivo antidiabetic activity. Bioconjug. Chem. 2015, 26, 120-127.

47. Wu, J.-W.; Wu, Y.-D.; Dai, J.-J.; Xu, H.-J. Benzoic Acid-Catalyzed Transamidation Reactions of Carboxamides, Phthalimide, Ureas and Thioamide with Amines. Adv. Synth. Catal. 2014, 356, 2429-2436. [CrossRef]

48. Abbas, M.A.; Hameed, S.; Kressler, J. Preparation of 2(3H)-Benzimidazolone and its Derivative Under Aqueous Condition As a Potential Agent for Antidiabetic Compounds. Asian J. Org. Chem. 2013, 25, 509-511. [CrossRef]

49. Francavilla, C.; Turtle, E.D.; Kim, B.; O’Mahony, D.J.R.; Shiau, T.P.; Low, E.; Alvarez, N.J.; Celeri, C.E.; D'Lima, L.; Friedman, L.C.; et al. Novel N-chloroheterocyclic antimicrobials. Bioorg. Med. Chem. Lett. 2011, 21, 3029-3033. [CrossRef]

50. Humphries, P.S.; Bersot, R.; Kincaid, J.; Mabery, E.; McCluskie, K.; Park, T.; Renner, T.; Riegler, E.; Steinfeld, T.; Turtle, E.D.; et al. Carbazole-containing amides and ureas: Discovery of cryptochrome modulators as antihyperglycemic agents. Bioorg. Med. Chem. Lett. 2018, 28, 293-297. [CrossRef]

51. Periasamy, J.; Kurdekar, V.; Jasti, S.; Nijaguna, M.; Boggaram, S.; Hurakadli, M.A.; Raina, D.; Kurup, L.M.; Chintha, C.; Manjunath, K.; et al. Targeting Phosphopeptide Recognition by the Human BRCA1 Tandem BRCT Domain to Interrupt BRCA1-Dependent Signaling. Cell Chem. Biol. 2018, 25, 677-690.

52. Chen, Z.; Mori, W.; Zhang, X.; Yamasaki, T.; Dunn, P.J.; Zhang, G.; Fu, H.; Shao, T.; Zhang, Y.; Hatori, A.; et al. Synthesis, pharmacology and preclinical evaluation of ${ }^{11} \mathrm{C}$-labeled 1,3-dihydro-2H-benzo[d]imidazole-2-ones for imaging $\gamma 8$-dependent transmembrane AMPA receptor regulatory protein. Eur. J. Med. Chem. 2018, 157, 898-908. [CrossRef] [PubMed]

53. Guo, J.; He, H.; Ye, Z.; Zhu, K.; Wu, Y.; Zhang, F. Highly Selective Palladium-Catalyzed Arene C-H Acyloxylation with Benzothiadiazole as a Modifiable Directing Group. Org. Lett. 2018, 20, 5692-5695.

54. Vincent, J.; Adura, C.; Gao, P.; Luz, A.; Lama, L.; Asano, Y.; Okamoto, R.; Imaeda, T.; Aida, J.; Rothamel, K.; et al. Small molecule inhibition of cGAS reduces interferon expression in primary macrophages from autoimmune mice. Nature Commun. 2018, 8, 750. [CrossRef] [PubMed]

55. Yoon, S.; Kim, J.H.; Koh, Y.; Tran, P.-T.; Ann, J.; Yoon, I.; Jang, J.; Kim, W.K.; Lee, S.; Lee, J.; et al. Discovery of simplified leucyladenylate sulfamates as novel leucyl-tRNA synthetase (LRS)-targeted mammalian target of rapamycin complex 1 (mTORC1) inhibitors. Bioorg. Med. Chem. 2017, 25, 4145-4152. [CrossRef] [PubMed]

56. Sun, C.-H.; Lu, Y.; Zhang, Q.; Lu, R.; Bao, L.-Q.; Shen, M.-H.; Xu, H.-D. Selective S-arylation of 2-oxazolidinethiones and selective $N$-arylation of 2-benzoxazolinones/2-benzimidazolinones. Org. Biomol. Chem. 2017, 15, 4058-4063. [CrossRef] [PubMed]

57. Garlets, Z.J.; Parenti, K.R.; Wolfe, J.P. Asymmetric Palladium-Catalyzed Alkene Carboamination Reactions for the Synthesis of Cyclic Sulfamides. Chem. Eur. J. 2016, 22, 5919-5922. [CrossRef] [PubMed] 
58. McDonald, C.E.; Ramsey, J.D.; McAtee, C.C.; Mauck, J.R.; Hale, E.M.; Cumens, J.A. The Use of Ureates as Activators for Samarium Diiodide. J. Org. Chem. 2016, 81, 5903-5914. [CrossRef] [PubMed]

59. Alberti, M.N.; Polyhach, Y.; Tzirakis, M.D.; Tçdtli, L.; Jeschke, G.; Diederich, F. Exploring the Strength of the H-Bond in Synthetic Models for Heme Proteins: The Importance of the $\mathrm{N} \notin \mathrm{H}$ Acidity of the Distal Base. Chem. Eur. J. 2016, 22, 10194-10202. [CrossRef]

60. Hesp, C.R.; MacDonald, M.J.; Zahedi, M.M.; Bilodeau, D.A.; Zhao, S.-B.; Pesant, M.; Beauchemin, A.M. Formaldehyde as Tethering Organocatalyst: Highly Diastereoselective Hydroaminations of Allylic Amines. Org. Lett. 2015, 17, 5136-5139. [CrossRef]

61. Doveston, R.G.; Tosatti, P.; Dow, M.; Foley, D.J.; Li, H.Y.; Campbell, A.J.; House, D.; Churcher, I.; Marsden, S.P.; Nelson, A. A unified lead-oriented synthesis of over fifty molecular molecular scaffolds. Org. Biomol. Chem. 2015, 13, 859-865. [CrossRef] [PubMed]

62. Neudorfer, C.; Seddik, A.; Shanab, K.; Jurik, A.; Rami-Mark, C.; Holzer, W.; Ecker, G.; Mitterhauser, M.; Wadsak, W.; Spreitzer, H. Synthesis and in Silico Evaluation of Novel Compounds for PET-Based Investigations of the Norepinephrine Transporter. Molecules 2015, 20, 1712-1720. [CrossRef]

63. Badru, R.; Singh, B. Synthesis of imidazolidin-2-ones employing dialkyl carbonates as an ecofriendly carbonylation source. RSC Adv. 2014, 4, 38978-38985. [CrossRef]

64. Liu, J.; Xie, Y.; Ye, L.; Yan, H.; Tu, S. Efficient and Green Preparation of 2-Imidazolidinone using Sulfamic Acid as Acidic Catalyst. Org. Prep. Proced. Int. 2014, 46, 453-456. [CrossRef]

65. Gabriele, B.; Costa, M.; Salerno, G.; Chiusoli, G.P. A New Synthesis of Trimethyl Aconitate by Palladium-catalysed Triple Carbonylation of Propynyl Alcohol. J. Chem. Soc., Chem. Commun. 1992, 1007-1008. [CrossRef]

66. Gabriele, B.; Costa, M.; Salerno, G.; Chiusoli, G.P. An Efficient and Selective Palladium-catalysed Oxidative Dicarbonylation of Alkynes to Alkyl- or Aryl-maleic Esters. J. Chem. Soc., Perkin Trans. 1 1994, 83-87. [CrossRef]

67. Gabriele, B. Synthesis of Heterocycles by Palladium-Catalyzed Carbonylative Reactions. In Advances in Transition-Metal Mediated Heterocyclic Synthesis; Solé, D., Fernández, I., Eds.; Academic Press-Elsevier: London, UK, 2018; pp. 55-127.

68. Gabriele, B.; Salerno, G.; Costa, M. Oxidative Carbonylations. Top. Organomet. Chem. 2006, 18, $239-272$.

69. Gabriele, B.; Salerno, G. PdI . In e-EROS (Electronic Encyclopedia of Reagents for Organic Synthesis); Crich, D., Ed.; Wiley-Interscience: New York, NY, USA, 2006.

70. Mancuso, R.; Ziccarelli, I.; Chimento, A.; Marino, N.; Della Ca', N.; Sirianni, R.; Pezzi, V.; Gabriele, B. Catalytic Double Cyclization Process for Antitumor Agents against Breast Cancer Cell Lines. iScience 2018, 3 , 279-288. [CrossRef]

71. Acerbi, A.; Carfagna, C.; Costa, M.; Mancuso, R.; Gabriele, B.; Della Ca', N. An Unprecedented Pd-Catalyzed Carbonylative Route to Fused Furo[3,4-b]indol-1-ones. Chem. Eur. J. 2018, 24, 4835-4840. [CrossRef]

72. Veltri, L.; Giofrè, S.; Devo, P.; Romeo, R.; Dobbs, A.P.; Gabriele, B. A Palladium Iodide-Catalyzed Oxidative Aminocarbonylation-Heterocyclization Approach to Functionalized Benzimidazoimidazoles. J. Org. Chem. 2018, 83, 1680-1685. [CrossRef] [PubMed]

73. Mancuso, R.; Veltri, L.; Russo, P.; Grasso, G.; Cuocci, C.; Romeo, R.; Gabriele, B. Palladium-Catalyzed Carbonylative Synthesis of Functionalized Benzimidazopyrimidinones. Synthesis 2018, 50, 267-277.

74. Pancrazzi, F.; Motti, E.; Costa, M.; Mancuso, R.; Gabriele, B.; Della Ca', N. (Z)-4-(carbomethoxymethylene)-2-(4-fluorophenyl)-4H-benzo[d][1,3]oxazine. Molbank 2017, 2017, M927. [CrossRef]

75. Veltri, L.; Grasso, G.; Rizzi, R.; Mancuso, R.; Gabriele, B. Palladium-Catalyzed Carbonylative Multicomponent Synthesis of Functionalized Benzimidazothiazoles. Asian J. Org. Chem. 2016, 5, 560-567. [CrossRef]

76. Mancuso, R.; Raut, D.S.; Marino, N.; De Luca, G.; Giordano, C.; Catalano, S.; Barone, I.; Andò, S.; Gabriele, B. A Palladium-Catalyzed Carbonylation Approach to Eight-Membered Lactam Derivatives with Antitumor Activity. Chem. Eur. J. 2016, 22, 3053-3064. [CrossRef]

77. Veltri, L.; Mancuso, R.; Altomare, A.; Gabriele, B. Divergent Multicomponent Tandem Palladium-Catalyzed Aminocarbonylation-Cyclication Approached to Functionalized Imidazothiazinones and Imidazothiazoles. ChemCatChem 2015, 7, 2206-2213. [CrossRef]

78. Gabriele, B.; Salerno, G.; Mancuso, R.; Costa, M. Efficient Synthesis of Ureas by Direct Palladium-Catalyzed Oxidative Carbonylation of Amines. J. Org. Chem. 2004, 69, 4741-4750. [CrossRef] [PubMed] 
79. Didgikar, M.R.; Joshi, S.S.; Gupte, S.P.; Diwakar, M.M.; Deshpande, R.M.; Chaudhari, R.V. Oxidative carbonylation of amine using water-soluble palladium catalysts in biphasic media. J. Mol. Catal. A: Chem. 2011, 334, 20-28. [CrossRef]

80. Kealey, S.; Husbands, S.M.; Bennacef, I.; Gee, A.D.; Passchier, J. Palladium-mediated oxidative reactions for the synthesis of ${ }^{11} \mathrm{C}$-radiolabelled ureas. J. Label. Compd. Radiopharm. 2014, 57, 202-208. [CrossRef]

81. Troisi, L.; Granito, C.; Perrone, S.; Rosato, F. Synthesis of benzo-fused five and six-membered heterocycles by palladium-catalyzed cyclocarbonylation. Tetrahedron Lett. 2011, 52, 4330-4332. [CrossRef]

82. Mizuno, T.; Nakai, T.; Mihara, M. Efficient Solvent-Free Synthesis of Urea Derivatives Using Selenium-Catalyzed Carbonylation of Amines with Carbon Monoxide. Synthesis 2010, 4251-4255. [CrossRef]

83. The $\mathrm{CO}-\mathrm{O}_{2}$ mixtures are potentially explosive over a large range of composition: the flammability range for $\mathrm{CO}$ in $\mathrm{O}_{2}$ is $16.7-93.5 \%$ at room temperature and it becomes even larger at higher temperatures. See:

84. Bartish, C.M.; Drissel, G.M. Kirk-Othmer Encyclopedia of Chemical Technology, 3rd ed.; Grayson, M., Eckroth, D., Bushey, G.J., Campbell, L., Klingsberg, A., van Nes, L., Eds.; John Wiley \& Sons: New York, NY, USA, 1978; Volume 4, p. 774.

85. Casiello, M.; Iannone, F.; Cotugno, P.; Monopoli, A.; Cioffi, N.; Ciminale, F.; Trzeciak, A.M.; Nacci, A. Copper(II)-catalysed oxidative carbonylation to oxazolidinones, ureas and carbamates. J. Mol. Catal. A:Chem. 2015, 407, 8-14. [CrossRef]

86. Wu, C.; Cheng, H.; Liu, R.; Wang, Q.; Hao, Y.; Yu, Y.; Zhao, F. Synthesis of urea derivatives from amines and $\mathrm{CO}_{2}$ in the absence of catalyst and solvent. Green Chem. 2010, 12, 1811-1816. [CrossRef]

87. Paz, J.; Pérez-Balado, C.; Iglesias, B.; Muñoz, L. Carbon Dioxide as a Carbonylating Agent in the Synthesis of 2-Oxazolidinones, 2-Oxazinones, and Cyclic Ureas: Scope and Limitations. J. Org. Chem. 2010, 75, 3037-3046. [CrossRef]

88. Kong, D.-L.; He, L.-N.; Wang, J.-Q. Synthesis of Urea Derivatives from $\mathrm{CO}_{2}$ and Amines Catalyzed by Polyethylene Glycol Supported Potassium Hydroxide without Dehydrating Agents. Synlett 2010, 1276-1280. [CrossRef]

89. Streng, E.S.; Lee, D.S.; George, M.W.; Poliakoff, M. Continuous N-alkylation reactions of amino alcohols using $\gamma-\mathrm{Al}_{2} \mathrm{O}_{3}$ and supercritical $\mathrm{CO}_{2}$ : unexpected formation of cyclic ureas and urethanes by reaction with $\mathrm{CO}_{2}$. Beilstein J. Org. Chem. 2017, 13, 329-337. [CrossRef] [PubMed]

90. Primo, A.; Aguado, E.; Garcia, H. $\mathrm{CO}_{2}$-Fixation on Aliphatic $\alpha, \omega$-Diamines fo Form Cyclic Ureas, Catalyzed by Ceria Nanoparticles that were Obtained by Templating with Alginate. ChemCatChem 2013, 5, 1010-1023. [CrossRef]

91. Tamura, M.; Noro, K.; Honda, M.; Nakagawa, Y.; Tomishige, K. Highly efficient synthesis of cyclic ureas from $\mathrm{CO}_{2}$ and diamines by a pure $\mathrm{CeO}_{2}$ catalyst using 2-propanol solvent. Green Chem. 2013, 15, 1567-1577. [CrossRef]

92. Xu, M.; Jupp, A.R.; Stephan, D.W. Stoichiometric Reactions of $\mathrm{CO}_{2}$ and Indium-Silylamides and Catalytic Synthesis of Ureas. Angew. Chem. Int. Ed. 2017, 56, 14277-14281. [CrossRef] [PubMed]

93. Yu, B.; Zhang, H.; Zhao, Y.; Chen, S.; Xu, J.; Hao, L.; Liu, Z. DBU-Based Ionic Liquid-Catalyzed Carbonylation of $o$-Phenylenediamines with $\mathrm{CO}_{2}$ to 2-Benzimidazolones under Solvent-Free Conditions. ACS Catal. 2013, 2, 2076-2082. [CrossRef]

94. Zhao, Y.; Wu, Y.; Yuan, G.; Hao, L.; Gao, X.; Yang, Z.; Yu, B.; Zhang, H.; Liu, Z. Azole-Anion-Based Aprotic Ionic Liquids: Functional Solvents for Atmospheric $\mathrm{CO}_{2}$ Transformation into Various Heterocyclic Compounds. Chem. Asian J. 2016, 11, 2735-2740. [CrossRef]

95. Kimura, T.; Kamata, K.; Mizuno, N. A Bifunctional Tungstate Catalyst for Chemical Fixation of $\mathrm{CO}_{2}$ at Atmospheric Pressure. Angew. Chem., Int. Ed. 2012, 51, 6700-6703. [CrossRef] [PubMed]

96. Kamata, K.; Kimura, T.; Sunaba, H.; Mizino, N. Scope of chemical fixation of carbon dioxide catalyzed by a bifunctional monomeric tungstate. Catal. Today 2014, 226, 160-166. [CrossRef]

97. Zhu, Y.; Cornwall, R.G.; Du, H.; Zhao, B.; Shi, Y. Catalytic Diamination of Olefins via N-N Bond Activation. Acc. Chem. Res. 2014, 47, 3665-3678. [CrossRef] [PubMed]

98. Muñiz, K.; Martínez, C. Development of Intramolecular Vicinal Diamination of Alkenes: From Palladium to Bromine Catalysis. J. Org. Chem. 2013, 78, 2168-2174. [CrossRef] [PubMed]

99. de Figueiredo, R.M. Transition-Metal-Catalyzed Diamination of Olefins. Angew. Chem. Int. Ed. 2009, 48, 1190-1193. [CrossRef]

100. Cardona, F.; Goti, A. Metal-catalysed 1,2-diamination reactions. Nat. Chem. 2009, 1, 269-275. [CrossRef] 
101. Streuff, J.; Hövelmann, C.H.; Nieger, M.; Muñiz, K. Palladium(II)-Catalyzed Intramolecular Diamination of Unfunctionalized Alkenes. J. Am. Chem. Soc. 2005, 127, 14586-14587. [CrossRef]

102. Muñiz, K.; Hövelmann, C.H.; Streuff, J. Oxidative Diamination of Alkenes with Ureas as Nitrogen Sources: Mechanistic Pathways in the Presence of a High Oxidation State Palladium Catalyst. J. Am. Chem. Soc. 2008, 130, 763-773. [CrossRef]

103. Muñiz, K.; Hövelmann, C.H.; Campos-Gómez, E.; Barluenga, J.; González, J.M.; Streuff, J.; Nieger, M. Intramolecular Diamination of Alkenes with Palladium(II)/Copper(II) Bromide and $\mathrm{IPy}_{2} \mathrm{BF}_{4}$ : The Role of Halogenated Intermediates. Chem. Asian J. 2008, 3, 776-788. [CrossRef] [PubMed]

104. Muñiz, K.; Streuff, J.; Chávez, P.; Hövelmann, C.H. Synthesis of Diamino Carboxylic Esters by Palladium-Catalyzed Oxidative Intramolecular Diamination of Acrylates. Chem. Asian J. 2008, 3, 1248-1255. [CrossRef] [PubMed]

105. Muñiz, K.; Streuff, J.; Hövelmann, C.H.; Núñez, A. Exploring the Nickel-Catalyzed Oxidation of Alkenes: A Diamination by Sulfamide Transfer. Angew. Chem. Int. Ed. 2007, 46, 7125-7127. [CrossRef] [PubMed]

106. Iglesias, A.; Muñiz, K. Oxidative Interception of the Hydroamination Pathway: A Gold-Catalyzed Diamination of Alkenes. Chem. Eur. J. 2009, 15, 10563-10569. [CrossRef] [PubMed]

107. Chávez, P.; Kirsch, J.; Hövelmann, C.H.; Streuff, J.; Martínez-Belmonte, M.; Escudero-Adán, E.C.; Martin, E.; Muñiz, K. Metal-free diamination of alkenes employing bromide catalysis. Chem. Sci. 2012, 3, 2375-2382. [CrossRef]

108. Muñiz, K. Metal-free catalytic vicinal diamination of alkenes. Pure Appl. Chem. 2013, 85, 755-761. [CrossRef]

109. Fu, S.; Yang, H.; Li, G.; Deng, Y.; Jiang, H.; Zeng, W. Copper(II)-Catalyzed Enantioselective Intramolecular Cyclization of N-Alkenylureas. Org. Lett. 2015, 17, 1018-1021. [CrossRef] [PubMed]

110. Li, H.; Widenhoefer, R.A. Gold(I)-Catalyzed Intramolecular Dihydroamination of Allenes with $N$, $N^{\prime}$-Disubstituted Ureas To Form Bicyclic Imidazolidin-2-ones. Org. Lett. 2009, 11, 2671-2674. [CrossRef] [PubMed]

111. Bar, G.L.J.; Lloyd-Jones, G.C.; Booker-Milburn, K.I. Pd(II)-Catalyzed Intermolecular 1,2-Diamination of Conjugated Dienes. J. Am. Chem. Soc. 2005, 127, 7308-7309. [CrossRef] [PubMed]

112. Wu, M.-S.; Fan, T.; Chen, S.-S.; Han, Z.-Y.; Gong, L.-Z. Pd(II)-Catalyzed Asymmetric Oxidative 1,2-Diamination of Conjugated Dienes with Ureas. Org. Lett. 2018, 20, 2485-2489. [CrossRef]

113. Du, H.; Yuan, W.; Zhao, B.; Shi, Y. Catalytic Asymmetric Diamination of Conjugated Dienes and Triene. J. Am. Chem. Soc. 2007, 129, 11688-11689. [CrossRef]

114. Du, H.; Zhao, B.; Shi, Y. A Facile Pd(0)-Catalyzed Regio- and Stereoselective Diamination of Conjugated Dienes and Trienes. J. Am. Chem. Soc. 2007, 129, 762-763. [CrossRef]

115. Zhao, B.; Du, H.; Cui, S.; Shi, Y. Synthetic and Mechanistic Studies on Pd(0)-Catalyzed Diamination of Conjugated Dienes. J. Am. Chem. Soc. 2010, 132, 3523-3532. [CrossRef] [PubMed]

116. Xu, L.; Du, H.; Shi, Y. Diamination of Conjugated Dienes and Trienes Catalyzed by N-Heterocyclic Carbene-Pd(0) Complexes. J. Org. Chem. 2007, 72, 7038-7041. [CrossRef] [PubMed]

117. Xu, L.; Shi, Y. Chiral N-Heterocyclic Carbene-Pd(0)-Catalyzed Asymmetric Diamination of Conjugated Dienes and Triene. J. Org. Chem. 2008, 73, 749-751. [CrossRef] [PubMed]

118. Du, H.; Yuan, W.; Zhao, B.; Shi, Y. A Pd(0)-Catalyzed Diamination of Terminal Olefins at Allylic and Homoallylic Carbons via Formal C-H Activation under Solvent-Free Conditions. J. Am. Chem. Soc. 2007, 129, 7496-7497. [CrossRef] [PubMed]

119. Du, H.; Zhao, B.; Shi, Y. Catalytic Asymmetric Allylic and Homoallylic Diamination of Terminal Olefins via Formal C-H Activation. J. Am. Chem. Soc. 2008, 130, 8590-8591. [CrossRef] [PubMed]

120. Fu, R.; Zhao, B.; Shi, Y. Synthesis of (+)-CP-99,994 via Pd(0)-Catalyzed Asymmetric Allylic and Homoallylic C-H Diamination of Terminal Olefin. J. Org. Chem. 2009, 74, 7577-7580. [CrossRef]

121. Ramirez, T.A.; Wang, Q.; Zhu, Y.; Zheng, H.; Peng, X.; Cornwall, R.G.; Shi, Y. Pd(0)-Catalyzed Sequential $\mathrm{C}-\mathrm{N}$ Bond Formation via Allylic and Aromatic C-H Amination of $\alpha$-Methylstyrenes with Diaziridinone. Org. Lett. 2013, 15, 4210-4213. [CrossRef]

122. Yuan, W.; Du, H.; Zhao, B.; Shi, Y. A Mild Cu(I)-Catalyzed Regioselective Diamination of Conjugated Dienes. Org. Lett. 2007, 9, 2589-2591. [CrossRef]

123. Du, H.; Zhao, B.; Yuan, W.; Shi, Y. Cu(I)-Catalyzed Asymmetric Diamination of Conjugated Dienes. Org. Lett. 2008, 10, 4231-4234. [CrossRef] 
124. Zhao, B.; Peng, X.; Cui, S.; Shi, Y. Cu(I)-Catalyzed Regioselective Diamination of Conjugated Dienes via Dual Mechanistic Pathways. J. Am. Chem. Soc. 2010, 132, 11009-11011. [CrossRef]

125. Zhao, B.; Peng, X.; Zhu, Y.; Ramirez, T.A.; Cornwall, R.G.; Shi, Y. Cu(I)-Catalyzed Diamination of Conjugated Dienes. Complementary Regioselectivity from Two Distinct Mechanistic Pathways Involving Cu(II) and Cu(III) Species. J. Am. Chem. Soc. 2011, 133, 20890-20900. [CrossRef] [PubMed]

126. Wen, Y.; Zhao, B.; Shi, Y. Cu(I)-Catalyzed Diamination of Disubstituted Terminal Olefins: An Approach to Potent $\mathrm{NK}_{1}$ Antagonist. Org. Lett. 2009, 11, 2365-2368. [CrossRef] [PubMed]

127. Patel, M.; Saunthwal, R.K.; Verma, A.K. Base-Mediated Hydroamination of Alkynes. Acc. Chem. Res. 2017, 50, 240-254. [CrossRef] [PubMed]

128. Huang, L.; Arndt, M.; Gooßen, K.; Heydt, H.; Gooßen, L.J. Late Transition Metal-Catalyzed Hydroamination and Hydroamidation. Chem. Rev. 2015, 115, 2596-2697. [CrossRef] [PubMed]

129. Müller, T.E.; Hultzsch, K.C.; Yus, M.; Foubelo, F.; Tada, M. Hydroamination: Direct Addition of Amines to Alkenes and Alkynes. Chem. Rev. 2008, 108, 3795-3892. [CrossRef] [PubMed]

130. Pohlki, F.; Doye, S. The Catalytic Hydroamination of Alkynes. Chem. Soc. Rev. 2003, 32, 104-114. [CrossRef]

131. Johns, A.M.; Sakai, N.; Ridder, A.; Hartwig, J.F. Direct Measurement of the Thermodynamics of Vinylarene Hydroamination. J. Am. Chem. Soc. 2006, 128, 9306-9307. [CrossRef]

132. Schlummer, B.; Hartwig, J.F. Brønsted Acid-Catalyzed Intramolecular Hydroamination of Protected Alkenylamines. Synthesis of Pyrrolidines and Piperidines. Org. Lett. 2002, 4, 1471-1474. [CrossRef]

133. Dion, I.; Beauchemin, A.M. Asymmetric Brønsted Acid Catalysis Enabling Hydroaminations of Dienes and Allenes. Angew. Chem. Int. Ed. 2011, 50, 8233-8235. [CrossRef]

134. Rodriguez, A.L.; Koradin, C.; Dohle, W.; Knochel, P. Versatile Indole Synthesis by a 5-Endo-Dig Cyclization Mediated by Potassium or Cesium Bases. Angew. Chem. Int. Ed. 2000, 39, 2488-2490. [CrossRef]

135. Seayad, J.; Tillack, A.; Hartung, C.G.; Beller, M. Base-Catalyzed Hydroamination of Olefins: An Environmentally Friendly Route to Amines. Adv. Synth. Catal. 2002, 344, 795-813. [CrossRef]

136. Herrero, M.T.; de Sarralde, J.D.; SanMartin, R.; Bravo, L.; Domínguez, E. Cesium Carbonate-Promoted Hydroamidation of Alkynes: Enamides, Indoles and the Effect of Iron(III) Chloride. Adv. Synth. Catal. 2012, 354, 3054-3064. [CrossRef]

137. Gooßen, L.J.; Rauhaus, J.E.; Deng, G. Ru-Catalyzed Anti-Markovnikov Addition of Amides to Alkynes: A Regio- and Stereoselective Synthesis of Enamides. Angew. Chem. Int. Ed. 2005, 44, 4042-4045. [CrossRef] [PubMed]

138. LaLonde, R.L.; Sherry, B.D.; Kang, E.J.; Toste, F.D. Gold(I)-Catalyzed Enantioselective Intramolecular Hydroamination of Allenes. J. Am. Chem. Soc. 2007, 129, 2452-2453. [CrossRef] [PubMed]

139. Pflästerer, D.; Dolbundalchok, P.; Rafique, S.; Rudolph, M.; Rominger, F.; Hashmi, A.S.K. On the Gold-Catalyzed Intramolecular 7-Exo-Trig Hydroamination of Allenes. Adv. Synth. Catal. 2013, 355, 1383-1393. [CrossRef]

140. Zhang, Z.; Lee, S.D.; Widenhoefer, R.A. Intermolecular Hydroamination of Ethylene and 1-Alkenes with Cyclic Ureas Catalyzed by Achiral and Chiral Gold(I) Complexes. J. Am. Chem. Soc. 2009, 131, 5372-5373. [CrossRef]

141. Shen, X.; Buchwald, S.L. Rhodium-Catalyzed Asymmetric Intramolecular Hydroamination of Unactivated Alkenes. Angew. Chem. 2010, 122, 574-577. [CrossRef]

142. Hannedouche, J.; Schulz, E. Hydroamination and Hydroaminoalkylation of Alkenes by Group 3-5 Elements: Recent Developments and Comparison with Late Transition Metals. Organomet. 2018. [CrossRef]

143. Gilmore, K.; Mohamed, R.K.; Alabugin, I.V. The Baldwin Rules: Revised and Extended: Baldwin: Revised, Extended. Wiley Interdiscip. Rev. Comp. Mol. Sci. 2016, 6, 487-514. [CrossRef]

144. Peshkov, V.A.; Pereshivko, O.P.; Sharma, S.; Meganathan, T.; Parmar, V.S.; Ermolat'ev, D.S.; Van der Eycken, E.V. Tetrasubstituted 2-Imidazolones via Ag(I)-Catalyzed Cycloisomerization of Propargylic Ureas. J. Org. Chem. 2011, 76, 5867-5872. [CrossRef]

145. Pereshivko, O.P.; Peshkov, V.A.; Jacobs, J.; Meervelt, L.V.; Van der Eycken, E.V. Cationic Gold-and Silver-Catalyzed Cycloisomerizations of Propargylic Ureas: A Selective Entry to Oxazolidin-2-Imines and Imidazolidin-2-Ones. Adv. Synth. Catal. 2013, 355, 781-789. [CrossRef]

146. La-Venia, A.; Medran, N.S.; Krchňák, V.; Testero, S.A. Synthesis of a Small Library of Imidazolidin-2-Ones Using Gold Catalysis on Solid Phase. ACS Comb. Sci. 2016, 18, 482-489. [CrossRef] [PubMed] 
147. Alamsetti, S.K.; Persson, A.K.Å.; Bäckvall, J.-E. Palladium-Catalyzed Intramolecular Hydroamination of Propargylic Carbamates and Carbamothioates. Org. Lett. 2014, 16, 1434-1437. [CrossRef] [PubMed]

148. Liu, J.; Shen, M.; Zhang, Y.; Li, G.; Khodabocus, A.; Rodriguez, S.; Qu, B.; Farina, V.; Senanayake, C.H.; Lu, B.Z. A New Entry to Polycyclic Indole Skeletons via Palladium-Catalyzed Intramolecular Heteroannulation. Org. Lett. 2006, 8, 3573-3575. [CrossRef] [PubMed]

149. Liu, J.; Zhang, Y.; Li, G.; Roschangar, F.; Farina, V.; Senanayake, C.H.; Lu, B.Z. A Novel One-Pot, Two-Step Synthesis of Polycyclic Indoles via Tandem Intramolecular Hydroamidation/Palladium-Catalyzed Annulation. Adv. Synth. Catal. 2010, 352, 2667-2671. [CrossRef]

150. Proulx, C.; Lubell, W.D. N-Amino-Imidazolin-2-One Peptide Mimic Synthesis and Conformational Analysis. Org. Lett. 2012, 14, 4552-4555. [CrossRef] [PubMed]

151. Ranjan, A.; Yerande, R.; Wakchaure, P.B.; Yerande, S.G.; Dethe, D.H. Base-Mediated Hydroamination of Propargylamine: A Regioselective Intramolecular 5-Exo-Dig Cycloisomerization En Route to Imidazole-2-Thione. Org. Lett. 2014, 16, 5788-5791. [CrossRef] [PubMed]

152. Huguenot, F.; Delalande, C.; Vidal, M. Metal-Free 5-Exo-Dig Cyclization of Propargyl Urea Using TBAF. Tetrahedron Lett. 2014, 55, 4632-4635. [CrossRef]

153. Arrowsmith, M.; Shepherd, W.M.S.; Hill, M.S.; Kociok-Köhn, G. Alkaline Earth Catalysis for the $100 \%$ Atom-Efficient Three Component Assembly of Imidazolidin-2-Ones. Chem. Commun. 2014, 50, 12676-12679. [CrossRef]

154. Martínez, A.; Moreno-Blázquez, S.; Rodríguez-Diéguez, A.; Ramos, A.; Fernández-Galán, R.; Antiñolo, A.; Carrillo-Hermosilla, F. Simple $\mathrm{ZnEt}_{2}$ as a Catalyst in Carbodiimide Hydroalkynylation: Structural and Mechanistic Studies. Dalton Trans. 2017, 46, 12923-12934. [CrossRef]

155. Fritz, J.A.; Nakhla, J.S.; Wolfe, J.P. A New Synthesis of Imidazolidin-2-Ones via Pd-Catalyzed Carboamination of N-Allylureas. Org. Lett. 2006, 8, 2531-2534. [CrossRef] [PubMed]

156. Fritz, J.A.; Wolfe, J.P. Stereoselective Synthesis of Imidazolidin-2-Ones via Pd-Catalyzed Alkene Carboamination. Scope and Limitations. Tetrahedron 2008, 64, 6838-6852. [CrossRef] [PubMed]

157. Hopkins, B.A.; Wolfe, J.P. Synthesis of Enantiomerically Enriched Imidazolidin-2-Ones through Asymmetric Palladium-Catalyzed Alkene Carboamination Reactions. Angew. Chem. Int. Ed. 2012, 51, 9886-9890. [CrossRef] [PubMed]

158. Shan, H.; Pan, R.; Lin, X. Synthesis and Application of a New Chiral Monodentate Spiro Phosphoramidite Ligand Based on Hexamethyl-1,1'-Spirobiindane Backbone in Asymmetric Hydroamination/Arylation of Alkenes. Org. Biomol. Chem. 2018, 16, 6183-6186. [CrossRef] [PubMed]

159. Peterson, L.J.; Kirsch, J.K.; Wolfe, J.P. Pd-Catalyzed Alkene Diamination Reactions of Nitrogen Electrophiles: Synthesis of Cyclic Guanidines and Ureas Bearing Dialkylaminomethyl Groups. Org. Lett. 2018, 20, 3513-3517. [CrossRef] [PubMed]

160. Sequeira, F.C.; Turnpenny, B.W.; Chemler, S.R. Copper-Promoted and Copper-Catalyzed Intermolecular Alkene Diamination. Angew. Chem. 2010, 122, 6509-6512. [CrossRef]

161. Zabawa, T.P.; Chemler, S.R. Copper(II) Carboxylate Promoted Intramolecular Diamination of Terminal Alkenes: Improved Reaction Conditions and Expanded Substrate Scope. Org. Lett. 2007, 9, 2035-2038. [CrossRef]

162. Xiong, P.; Xu, F.; Qian, X.-Y.; Yohannes, Y.; Song, J.; Lu, X.; Xu, H.-C. Copper-Catalyzed Intramolecular Oxidative Amination of Unactivated Internal Alkenes. Chem. Eur. J. 2016, 22, 4379-4383. [CrossRef]

163. Li, H.; Song, F.; Widenhoefer, R.A. Gold(I)-Catalyzed Intramolecular Hydroamination of N-Allylic $\mathrm{N}^{\prime}$-Arylureas to Form Imidazolidin-2-Ones. Adv. Synth. Catal. 2011, 353, 955-962. [CrossRef]

164. Zhang, G.; Luo, Y.; Wang, Y.; Zhang, L. Combining Gold(I)/Gold(III) Catalysis and C-H Functionalization: A Formal Intramolecular [3+2] Annulation towards Tricyclic Indolines and Mechanistic Studies. Angew. Chem. Int. Ed. 2011, 50, 4450-4454. [CrossRef]

165. Manick, A.-D.; Aubert, S.; Yalcouye, B.; Prangé, T.; Berhal, F.; Prestat, G. Access to Functionalized Imidazolidin-2-One Derivatives by Iron-Catalyzed Oxyamination of Alkenes. Chem. Eur. J. 2018, 24, 11485-11492. [CrossRef] [PubMed]

166. Baeg, J.-O.; Alper, H. Novel Palladium(II)-Catalyzed Cyclization of Aziridines and Sulfur Diimides. J. Am. Chem. Soc. 1994, 116, 1220-1224. [CrossRef] 
167. Butler, D.C.D.; Inman, G.A.; Alper, H. Room Temperature Ring-Opening Cyclization Reactions of 2-Vinylaziridines with Isocyanates, Carbodiimides, and Isothiocyanates Catalyzed by $\left[\mathrm{Pd}(\mathrm{OAc})_{2}\right] / \mathrm{PPh}_{3}$. J. Org. Chem. 2000, 65, 5887-5890. [CrossRef] [PubMed]

168. Trost, B.M.; Fandrick, D.R. Dynamic Kinetic Asymmetric Cycloadditions of Isocyanates to Vinylaziridines. J. Am. Chem. Soc. 2003, 125, 11836-11837. [CrossRef]

169. Dong, C.; Alper, H. CeCl3 promoted asymmetric cycloaddition of isocyanates with 2-vinylaziridines. Tetrahedron: Asymmetry 2004, 15, 1537-1540. [CrossRef]

170. Okano, A.; Oishi, S.; Tanaka, T.; Fujii, N.; Ohno, H. Construction of Linked Nitrogen Heterocycles by Palladium(0)-Catalyzed Intramolecular Domino Cyclization of 2-Alkynylaziridines Bearing a 2-Aminoethyl Group via Ring Expansion with Isocyanate. J. Org. Chem. 2010, 75, 3396-3400. [CrossRef] [PubMed]

171. Munegumi, T.; Azumaya, I.; Kato, T.; Masu, H.; Saito, S. [3+2] Cross-Coupling Reactions of Aziridines with Isocyanates Catalyzed by Nickel(II) Iodide. Org. Lett. 2006, 8, 379-382. [CrossRef]

172. Zhang, K.; Chopade, P.R.; Louie, J. Coupling of vinyl aziridines and phenyl isocyanate. Tetrahedron Lett. 2008, 49, 4306-4309. [CrossRef]

173. Nadir, U.K.; Krishna, R.V.; Singh, A. A new and facile route for the synthesis of chiral 1,2-diamines and 2,3-diamino acids. Tetrahedron Lett. 2005, 46, 479-482. [CrossRef]

174. Kim, M.S.; Kim, Y.-W.; Hahm, H.S.; Jang, J.W.; Lee, W.K.; Ha, H.-J. Lewis acid-catalyzed stereospecific ring expansion of aziridine-2-carboxylates to imidazolidin-2-ones. Chem. Commun. 2005, 3062-3064. [CrossRef]

175. Eum, H.-S.; Lee, Y.-N.; Kim, S.-M.; Baek, A.-Y.; Son, M.-K.; Lee, K.-W.; Ko, S.-W.; Kim, S.-H.; Yun, S.-Y.; Lee, W.-K.; et al. Synthesis of Substituted Imidazolidin-2-ones as Aminoacyl-tRNA Synthase Inhibitors. Bull. Korean Chem. Soc. 2010, 31, 611-614. [CrossRef]

176. Yoon, D.-H.; Ha, H.-J.; Kim, B.C.; Lee, W.K. Conjugate addition of amines to chiral 3-aziridin-2-yl-acrylates. Tetrahedron Lett. 2010, 51, 2181-2183. [CrossRef]

177. Tabarki, M.A.; Besbes, R. Ring expansion of aziridine-2-carboxylates. An efficient entry to imidazolidin-2-ones and oxazolidin-2-imines. Tetrahedron Lett. 2015, 56, 1837-1839. [CrossRef]

178. Hinds, E.M.; Wolfe, J.P. A Cross-Metathesis/Aza-Michael Reaction Strategy for the Synthesis of Cyclic and Bicyclic Ureas. J. Org. Chem. 2018, 83, 10668-10676. [CrossRef] [PubMed]

179. Kondoh, A.; Kamata, Y.; Terada, M. Synthesis of Enantioenriched $\gamma$-Amino- $\alpha, \beta$-Unsaturated Esters Utilizing Palladium-Catalyzed Rearrangement of Allylic Carbamates for Direct Application to Formal $[3+2]$ Cycloaddition. Org. Lett. 2017, 19, 1682-1685. [CrossRef] [PubMed]

180. Jin, H.; Dai, C.; Huang, Y. DBU-Catalyzed Desymmetrization of Cyclohexadienones: Access to Vicinal Diamine-Containing Heterocycles. Org. Lett. 2018, 20, 5006-5009. [CrossRef] [PubMed]

181. Kutovaya, I.V.; Shmatova, O.I.; Tkachuk, V.M.; Melnichenko, N.V.; Vovk, M.V.; Nenajdenko, V.G. Aza-Henry Reaction with $\mathrm{CF}_{3}$-Ketimines: An Efficient Approach to Trifluoromethylated $\beta$-Nitroamines, 1,2-Diamines, $\alpha$-Aminooximes, and Imidazolidinones: Aza-Henry Reaction with $\mathrm{CF}_{3}$-Ketimines. Eur. J. Org. Chem. 2015, 2015, 6749-6761. [CrossRef]

182. Wiebe, A.; Gieshoff, T.; Möhle, S.; Rodrigo, E.; Zirbes, M.; Waldvogel, S.R. Electrifying Organic Synthesis. Angew. Chem. Int. Ed. 2018, 57, 5594-5619. [CrossRef] [PubMed]

183. Xiong, P.; Xu, H.-H.; Xu, H.-C. Metal- and Reagent-Free Intramolecular Oxidative Amination of Tri- and Tetrasubstituted Alkenes. J. Am. Chem. Soc. 2017, 139, 2956-2959. [CrossRef]

184. Ahmed, N.; Khatoon, S. Facile Electrochemical Intramolecular Amination of Urea-Tethered Terminal Alkenes for the Synthesis of Cyclic Ureas. ChemistryOpen 2018, 7, 576-582. [CrossRef]

185. Strambeanu, I.I.; White, M.C. Catalyst-Controlled C-O versus C-N Allylic Functionalization of Terminal Olefins. J. Am. Chem. Soc. 2013, 135, 12032-12037. [CrossRef] [PubMed]

186. Xu, F.; Shuler, S.A.; Watson, D.A. Synthesis of N-H Bearing Imidazolidinones and Dihydroimidazolones Using Aza-Heck Cyclizations. Angew. Chem. Int. Ed. 2018, 57, 12081-12085. [CrossRef] [PubMed]

187. Yu, J.; Gao, C.; Song, Z.; Yang, H.; Fu, H. Metal-Free Oxidative C-H Amidation of N, N'-Diarylureas with $\mathrm{PhI}(\mathrm{OAc})_{2}$ : Synthesis of Benzimidazol-2-One Derivatives: Metal-Free Oxidative C-H Amidation of $N$, $N^{\prime}$-Diarylureas. Eur. J. Org. Chem. 2015, 5869-5875. [CrossRef] 
188. Zeng, R.; Chen, P.; Dong, G. Efficient Benzimidazolidinone Synthesis via Rhodium-Catalyzed Double-Decarbonylative C-C Activation/Cycloaddition between Isatins and Isocyanates. ACS Catal. 2016, 6, 969-973. [CrossRef] [PubMed]

189. Marchegiani, M.; Nodari, M.; Tansini, F.; Massera, C.; Mancuso, R.; Gabriele, B.; Costa, M.; Della Ca', N. Urea derivatives from carbon dioxide and amines by guanidine catalysis: Easy access to imidazolidin-2-ones under solvent-free conditions. J. $\mathrm{CO}_{2}$ Util. 2017, 21, 553-561. [CrossRef]

(c) (1)

(C) 2019 by the authors. Licensee MDPI, Basel, Switzerland. This article is an open access article distributed under the terms and conditions of the Creative Commons Attribution (CC BY) license (http:/ / creativecommons.org/licenses/by/4.0/). 